\title{
Professional Financial Advice, Self-Control and Saving Behavior
}

\section{DISSERTATION}

Presented in Partial Fulfillment of the Requirements for the Degree Doctor of Philosophy in the Graduate School of The Ohio State University

\author{
By \\ Fen Liu \\ Graduate Program in Human Ecology \\ The Ohio State University \\ 2014 \\ Dissertation Committee: \\ Dr. Tansel Yilmazer, Advisor \\ Dr. Caezilia Loibl \\ Dr. Catherine P. Montalto \\ Dr. Robert L. Scharff \\ Dr. Lucia Dunn
}


Copyrighted by

Fen Liu

2014 


\begin{abstract}
The purpose of this study is to examine the effects of professional financial advice (PFA) and self-control ability on saving behaviors, as well as the interaction of PFA and self-control on saving behaviors. Professional financial advisors can use their financial expertise to help households make financial decisions, especially for those who lack financial literacy. Professional financial advisors may help households achieve better self-control in implementing financial plans, such as recommending commitment devices. The contribution of this study is to investigate saving behaviors by considering professional financial advice and self-control together.

I extend the dual-self model of impulse control and derive three hypotheses from the theoretical model. The first hypothesis is that people with higher levels of self-control save more than those with lower levels of self-control. The second hypothesis is that professional financial advice has a positive effect on saving behaviors. The third hypothesis is that people with lower levels of self-control benefit more from getting PFA than those with higher levels of self-control.
\end{abstract}

This study uses a German household panel dataset SAVE, which is collected annually from 2005 to 2009. Respondents are asked whether they discuss financial 
matters with financial advisors in banks, insurance companies or financial service providers. Using a number of behavioral proxies of self-control, I create an aggregate measure of self-control using the method of factor analysis via maximum likelihood estimation. I estimate a fixed-effects model to identify the effects of PFA and self-control on saving behavior.

Empirical results find a significant positive relationship between PFA and shortrun saving behaviors, such as savings out of windfall, annual total savings, and own pension contribution. There is a significant positive relationship between PFA and longrun financial outcomes, such as emergency funds, financial assets, illiquid assets and total assets. These empirical results provide evidence to support the hypothesis about the positive relationship between PFA and saving behaviors. I also find that the self-control ability has a significant positive relationship with annual total savings, emergency funds, financial assets and total assets. These empirical results support the hypothesis about the positive relationship between self-control ability and saving behaviors. The interaction term of PFA and self-control has a significant negative relationship with financial assets and total loans, at the 0.1 significance level. These findings support the hypothesis that people with lower levels of self-control can benefit more by getting professional financial advice than those with higher levels of self-control. 


\section{Acknowledgments}

I am deeply grateful to my advisor, Dr. Tansel Yilmazer, for her support and guidance to me, especially during the dissertation process. I do appreciate the experiences to work as a research assistant for her in the past two years, and I have learned a lot from her. Her continued guidance and help to me is what I will always remember and appreciate.

I am very grateful to Dr. Caezilia Loibl who had served as my co-advisor and later a committee member. She suggested the dataset SAVE for my dissertation, and I do appreciate her continued help to me in my research, especially at the beginning stage of my dissertation. I feel very grateful to Dr. Catherine Montalto and Dr. Rob Scharff who have served on my committee and provided valuable feedback throughout the process. I want to express my deep thanks to Dr. Lucia Dunn, and I do appreciate her suggestions and help to me in the past years. I also acknowledge Dr. Sherman Hanna for his help and support to me in this program.

Finally, I am very grateful for the indispensable support I have received from my parents, family and friends in the past years. I will always cherish the memory with my friends at The Ohio State University in my life. 
Vita

of Economics, The Ohio State University
of Human Sciences, The Ohio State
University

\section{Fields of Study}

Major Field: Human Ecology 


\section{Table of Contents}

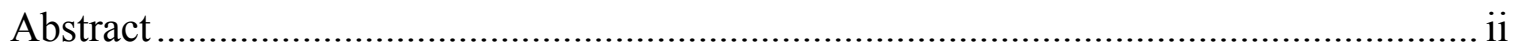

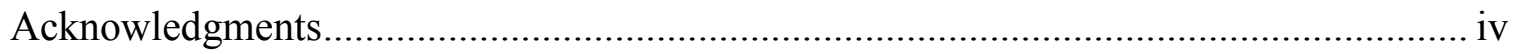

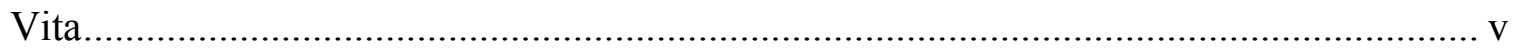

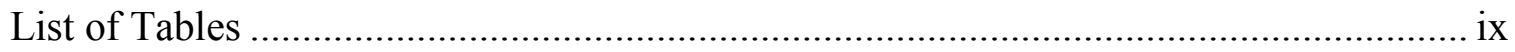

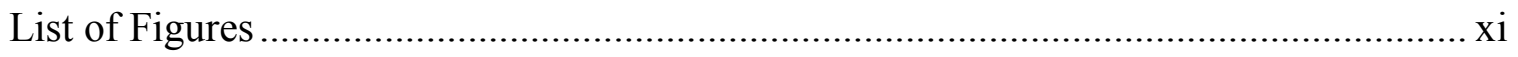

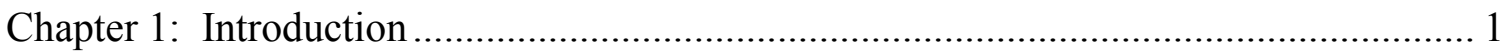

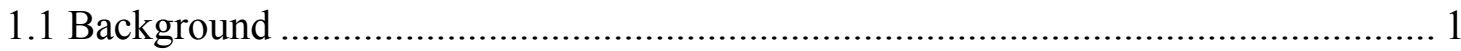

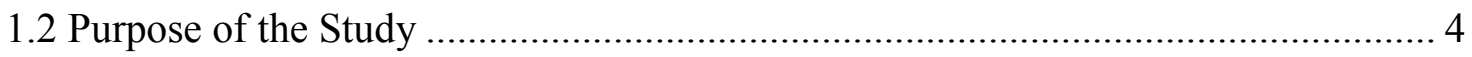

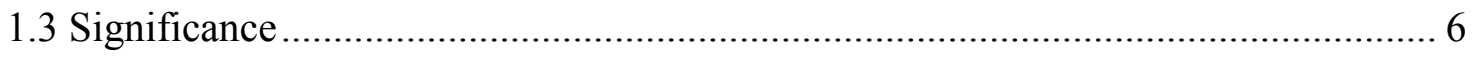

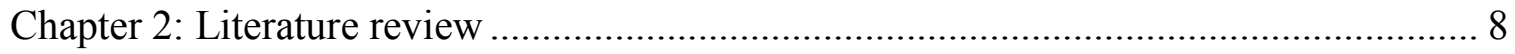

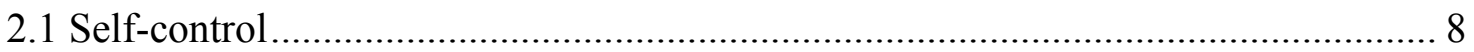

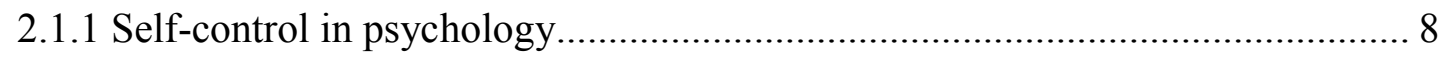

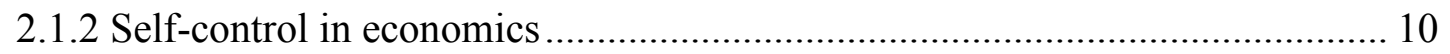

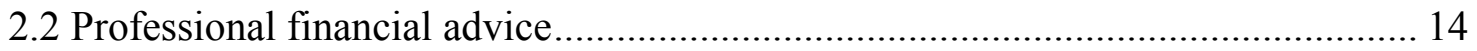

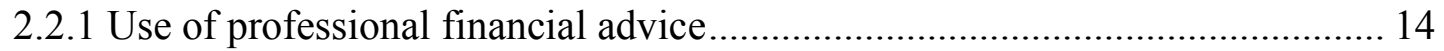

2.2.2 Professional financial advice and retirement planning ................................ 17 


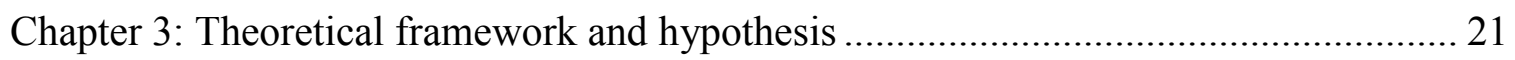

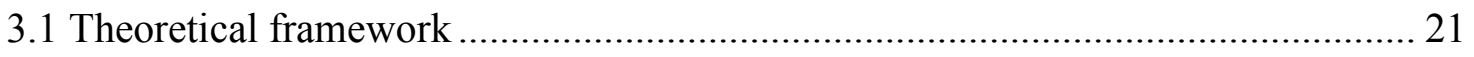

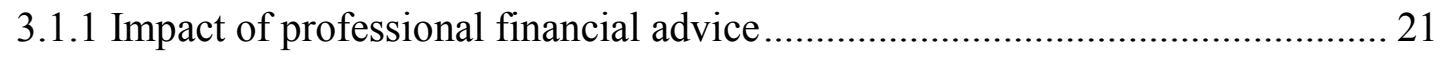

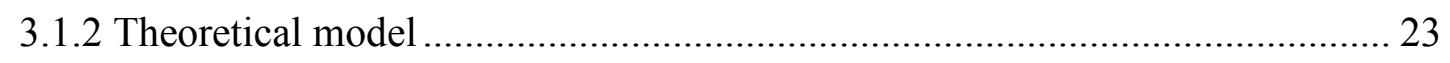

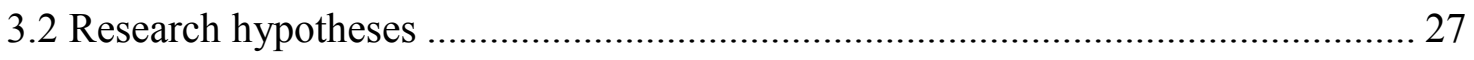

Chapter 4. Research design and Methodology ..................................................... 31

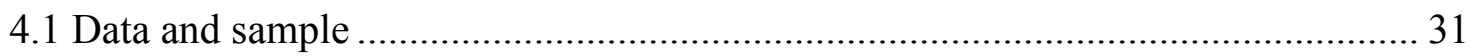

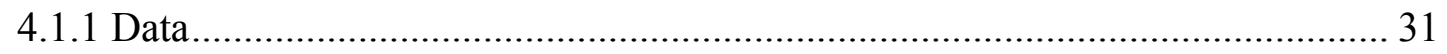

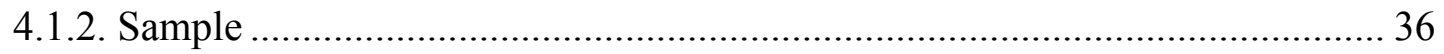

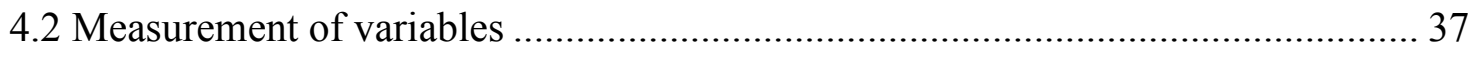

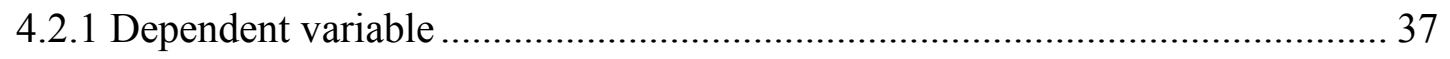

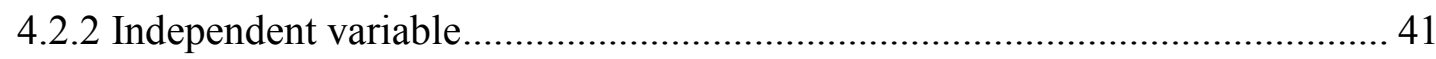

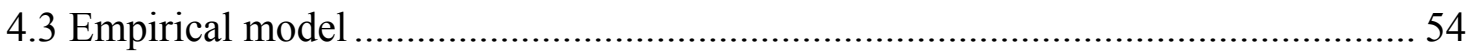

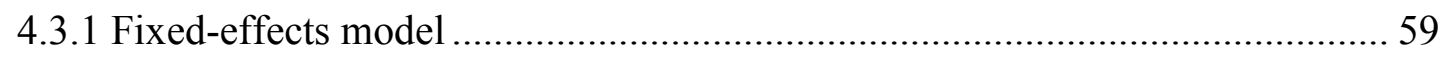

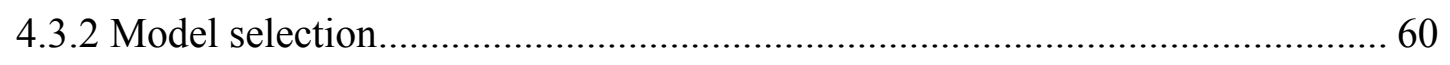

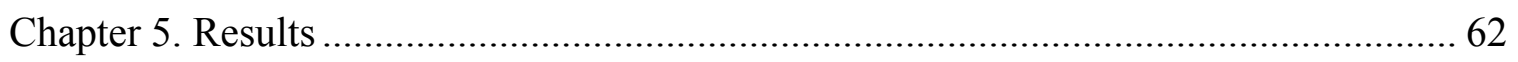

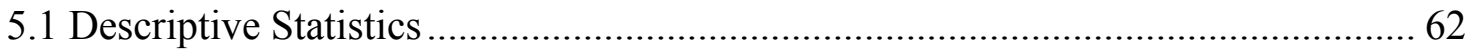

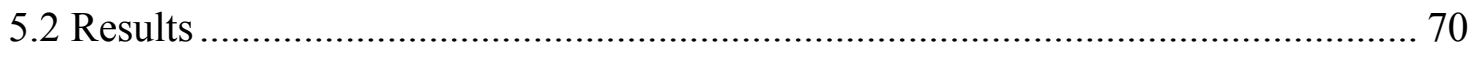


5.2.1 Short-run saving behaviors

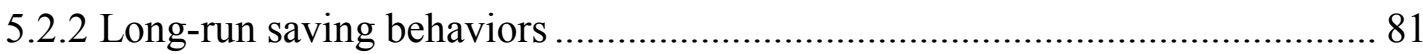

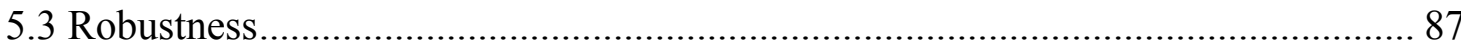

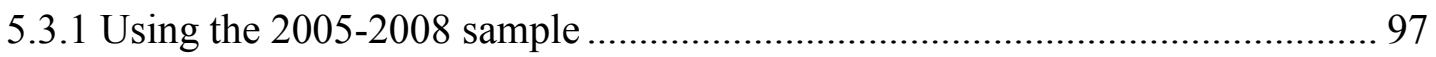

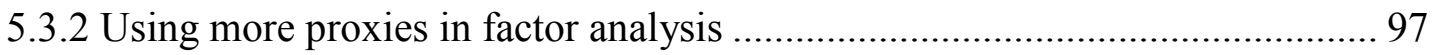

5.3.3 Using the unimputed data for key variables ......................................... 100

5.3.4 Using lagged independent variables .................................................. 101

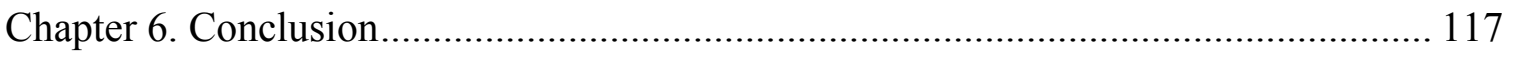

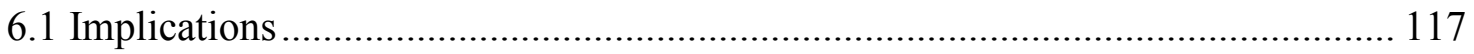

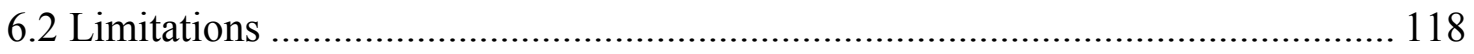

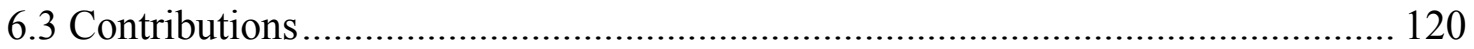

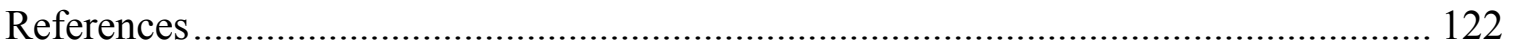

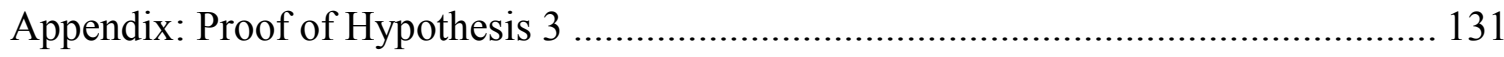




\section{List of Tables}

Table 4.1: Structure of the SAVE questionnaire .......................................................... 32

Table 4.2: Frequency of advice-seeking in 2005-2009................................................. 42

Table 4.3. Factor analysis to create an aggregate measure of self-control in 2005-2009. 48

Table 4.4: Variables and corresponding questions …………………........................... 54

Table 5.1. Descriptive statistics of income and savings (in Euro) .................................... 64

Table 5.2: Descriptive statistics of advice-seeking behaviors and self-control measures 65

Table 5.3: Descriptive statistics of socioeconomic characteristics (Head) ........................ 67

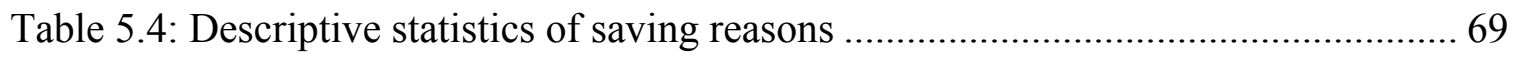

Table 5.5: MI estimates of a fixed-effects model for saving behaviors............................ 77

Table 5.6: MI estimates of a fixed-effects model for saving behaviors............................. 78

Table 5.7: MI estimates of a fixed-effects model for saving behaviors............................ 79

Table 5.8: MI estimates of a fixed-effects model for saving behaviors............................ 80

Table 5.9: MI estimates of a fixed-effects model in the 2005-2008 sample..................... 89

Table 5.10: MI estimates of a fixed-effects model in the 2005-2008 sample................... 90

Table 5.11: MI estimates of a fixed-effects model in the 2005-2008 sample................... 91

Table 5.12: MI estimates of a fixed-effects model in the 2005-2008 sample.................. 92

Table 5.13: MI estimates of a fixed-effects model with 5 proxies for factor analysis ..... 93 ix 
Table 5.14: MI estimates of a fixed-effects model with 5 proxies for factor analysis ..... 94

Table 5.15: MI estimates of a fixed-effects model with 5 proxies for factor analysis ..... 95

Table 5.16: MI estimates of a fixed-effects model with 5 proxies for factor analysis ..... 96

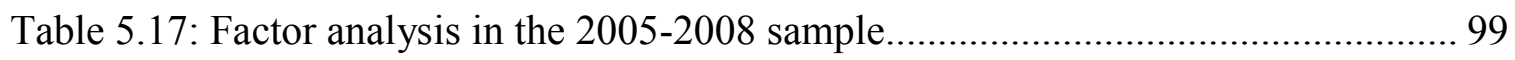

Table 5.18: Fixed-effects regressions by using unimputed data................................. 105

Table 5.19: Fixed-effects regressions by using unimputed data................................ 106

Table 5.20: Fixed-effects regressions by using unimputed data ................................ 107

Table 5.21: Fixed-effects regressions by using unimputed data................................. 108

Table 5.22: Fixed-effects regressions by using lagged independent variables .............. 109

Table 5.23: Fixed-effects regressions by using lagged independent variables ............... 110

Table 5.24: Fixed-effects regressions by using lagged independent variables ............... 111

Table 5.25: Fixed-effects regressions by using lagged independent variables .............. 112

Table 5.26: OLS regressions by using lagged independent variables ......................... 113

Table 5.27: OLS regressions by using lagged independent variables ......................... 114

Table 5.28: OLS regressions by using lagged independent variables ......................... 115

Table 5.29: OLS regressions by using lagged independent variables ......................... 116 


\section{List of Figures}

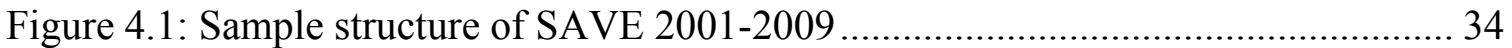




\section{Chapter 1: Introduction}

The purpose of this study is to examine the effect of professional financial advice and self-control on household saving behavior. The first section of this chapter provides a background description of the growing importance of professional financial advice in

household decision making in recent decades. The second section explains the purpose of this study. Finally, the third section discusses the significance and policy implications of the study.

\subsection{Background}

In the past decade, it has become more common for households to make financial decisions with the help from professional financial advisors. For example, the Survey of Consumer Finances (SCF) shows that the use of financial planners among American households has increased from 20\% in 2001 to 25\% in 2007 (Hanna \& Lindamood, 2010). There are at least three reasons behind the growing importance of professional financial advice in household decision making.

First, in increasingly complex and volatile financial markets, many households find it difficult to make financial decisions by themselves, and some households make 
investment mistakes in their financial management (Campbell, 2006; Fischer \& Gerhardt, 2007). In the financial market with thousands of common stocks, many individual investors without professional help tend to consider buying stocks that have recently caught their attention, while professional investors are able to search stocks widely and to employ explicit selection criteria (Barber \& Odean, 2008). Furthermore, there is evidence that individual investors tend to sell their winning stocks, but keep ones that have dropped in value, and this phenomenon is documented as the disposition effect in behavioral finance (Odean, 1998; Shefrin \& Statman, 1985). Barber and Odean (2000) analyze household stock trading behavior and find that individual investors tend to trade more frequently and often get a lower return than other investors. Given these facts, professional financial advisors may help individual investors make informed investment choices and avoid some investment mistakes.

Second, the responsibility of retirement preparation has become individuals' responsibility since defined-contribution plans have replaced many defined-benefit plans in the past decades (Thaler \& Benartzi, 2004). If employees contribute enough savings to their defined contribution plans in their working years, they will receive adequate retirement income. However, about half of households do not save enough for retirement and may have problems to maintain their standard of living after retirement (Munnell, Webb, \& Golub-Sass 2007). Moreover, in the 2004 Health and Retirement Study (HRS), there are less than one-fifth respondents who have successfully developed retirement saving plans (Lusardi \& Mitchell, 2006). Lusardi and Mitchell (2006) find that 
households with retirement plans are more likely to consult professional financial advisors or attend retirement seminars, and less likely to rely on relatives or co-workers.

Third, many households have potential financial problems associated with lower levels of self-control, such as low saving rates, lack of emergency-fund savings, and over-indebtedness. Empirical studies find that many households hold few assets and even lack emergency-fund savings, which makes them financially fragile (Lusardi, Schneider, \& Tufano, 2011). Gathergood (2012) find that individuals with self-control problems make more use of quick-access and high-cost credit items such as payday loans, which may result in over-indebtedness. Professional financial advisors can help households improve their self-control ability as well as deal with financial problems. In the practice of financial counseling, a self-control model has been proposed for more effective financial management (Bagarozzi \& Bagarozzi, 1980). They propose that financial counselors can design intervention procedures, such as budgeting, in the first interview with family members. The results of intervention treatment will be discussed and evaluated in the second and third interviews.

Fourth, households can benefit from seeking professional financial advice by getting updated financial and policy information. Financial planning is a broad subject, which covers budgeting, income tax planning, investment planning, retirement planning, risk management, and estate planning (McLellan, 2012). It takes time and efforts to get familiar with each major area in financial planning for households themselves. It is also important to consider new policies in making financial plans in order to make optimal 
financial plans. Therefore, professional financial advisors can use their financial expertise and information advantage to help households make financial decisions (Collins, 2010). Some economists suggest that professional financial advisors are helpful to the public, and recommend that the federal government should subsidize professional financial advice (Shiller, 2009). Cummings and James (2013) use data from the Study of Assets and Health Dynamics Among the Oldest Old (AHEAD), and find that seeking professional financial advice has a significant positive relationship with subsequent net worth for senior people. However, there is limited evidence in the literature about the positive impact of professional financial advice on general households over time (Marsden, Zick, \& Mayer, 2011).

\subsection{Purpose of the Study}

Given the growing importance of professional financial advice, more attention should be paid to its role in household financial management. In the empirical literature, professional financial advice is often recommended as a method to help some households improve financial literacy. The definition of financial literacy contains both financial knowledge and the competency to make appropriate financial decisions (Remund, 2010). Even among people with sufficient financial knowledge, those with lower levels of selfcontrol may lack the competency to make good financial decisions. Financial illiteracy is considered to be a determinant of lower household savings and investment (Hilgert, Hogarth, \& Beverly, 2003; Lusardi, 2004; Lusardi \& Mitchelli, 2007). However, a recent meta-analysis study finds that the effects of financial literacy diminishes dramatically 
after controlling for some omitted variables, such as psychological traits (Fernandes, Lynch, \& Netemeyer, 2013). Since the effect of financial education is found to decay quickly over time, Fernandes et al. (2013) recommend "just in time" financial advice tied to specific decisions to help households make financial decisions.

The theoretical literature emphasizes the self-control ability as an important factor in household saving behaviors. Shefrin and Thaler (1988) propose a planner-doer model to understand household consumption and saving behaviors by taking into consideration self-control, mental accounting and framing. Fudenberg and Levine (2006) extend the planner-doer model into a more general dual-self model of impulse control, and provide a simple savings model with self-control cost. Empirical studies have found that lower levels of self-control are associated with lower household wealth, as well as higher credit card debts (Ameriks, Caplin, Leahy, \& Tyler, 2007). The first purpose of this study is to explore the role of professional financial advice in household saving behavior. The main contribution is to extend the simple savings model in Fudenberg and Levine (2006) to explore the interaction of professional financial advice and self-control on household savings.

The second purpose is to evaluate the effect of professional financial advice on household savings over time. Previous empirical studies mainly use cross-sectional survey to investigate the effect of professional financial advice, such as the Survey of Consumer Finances (SCF) and the National Financial Capability Study (NFCS) (Hastings, Madrian, \& Skimmyhorn, 2013; Lachance \& Tang, 2012). Since both SCF and NFCS are cross-sectional datasets, there are some limitations for them to provide 
evidence about the impact of professional financial advice over time. This study will make use of a panel dataset to examine how the relationship between professional financial advice and households' financial behaviors manifests itself over time.

Furthermore, I will use a fixed-effect model to control for unobserved heterogeneity that is constant over time and is correlated with independent variables. This research will study the effects of professional financial advice on short-run saving behaviors (e.g., annual savings out of windfall income, and annual total savings) and long-run financial outcomes (e.g. emergency-funds, financial assets, illiquid assets and total assets).

\subsection{Significance}

This study will contribute to the literature on professional financial advice, selfcontrol, and saving behavior in two important ways.

First, this policy-relevant research aims to provide policy recommendations for guiding the regulation of the financial advice industry. In the past decade, the supply of financial advisors has grown to satisfy the rising demand of professional financial advice. Based on the data from the U.S. Bureau of Labor Statistics (BLS), 223,400 individuals were employed as personal financial advisors in 2012. The BLS estimates that this figure will increase $27 \%$ in the next ten years, which is much faster than the average growth rate $11 \%$ among all occupations. Related to the financial advising field, there are at least eight professional certifications: Accredited Financial Counselor (AFC), Accredited Investment Fiduciary (AIF), Certified Financial Planner (CFP), Certified Public Accountant (CPA), Chartered Financial Analyst (CFA), Chartered Financial Consultant 
(ChFC), Chartered Life Underwriter (CLU), and Personal Financial Specialist (PFS). The numbers of individuals who hold each certification are expected to increase in the future. From these facts about the financial advising fields, I can expect that the financial advice industry will grow into an important one in the near future (Collins, 2010). However, there are few studies about this diverse field until the recent years in academia. My research provides new evidence about the impact of professional financial advice on household saving behavior, which can help inform policy decisions regarding the value of professional financial advice.

Second, the results from this study will help professional financial service providers have a better understanding of their potential impact on households with different self-control ability. In practice, some professional financial advisors may overlook the necessity to examine their clients' self-control ability which plays a critical role in implementing financial plans. Therefore, if one client has self-control problems, this study recommends that professional financial advisors may provide some commitment devices to the client and help improve self-control ability first as well as providing some financial suggestions. Actually, the empirical analysis in this study shows that households with lower levels of self-control can benefit more from seeking professional financial advice, since professional financial advisors can provide some help in improving their self-control ability. 


\section{Chapter 2: Literature review}

This chapter will thoroughly review the theoretical and empirical literature about self-control and professional financial advice. The first section will discuss the relevant self-control theories roughly in chronological order, and then summarize how self-control is measured in economics and psychology. The second section will review the literature about the factors related with seeking professional financial advice and the impact of professional financial advice on retirement planning and investment decisions.

\subsection{Self-control}

\subsubsection{Self-control in psychology}

In the psychology literature, self-control is related with several concepts, such as self-regulation, impulsivity, delayed gratification, and willpower. In a seminal study, Mischel, Ebbesen, and Zeiss (1972) presented four-year-old children with one cookie, and told them that they would receive another cookie as a reward if they did not eat the cookie on the table and wait until the experimenter came back. The cookie on the table is a salient temptation, a child needs to exert willpower to inhibit impulse and achieve selfcontrol. Those four-year-old children with successful goal-directed delay of gratification 
in experiments are found to have more cognitive and social competence in young adulthood, such as higher SAT scores in math (Mischel, Shoda, \& Rodriguez, 1989). Most theoretical explanation of self-control in psychology is based on the dual-systems theories and emphasizes the intra-psychic conflict between impulse activation and effortful impulse inhibition. For example, Metcalfe and Mischel (1999) propose a hotcool system framework to understand self-control and willpower in the delay of gratification. Loewenstein (1996) studies visceral versus rational decision making, and emphasizes the influence of visceral factors on impulsivity and self-control.

In the domain of financial decisions, studies suggest that self-control or selfregulation can help people refrain from consumption impulses (Baumeister, 2002; Wärneryd, 1999). Baumeister (2002) defines "self-control” or "self-regulation" as the self's capacity to alter its own responses in the face of temptations. Within consumer behaviors, self-control is defined as the capacity to resist temptations, especially impulsive purchases that are likely to be regretted later on. They suggest that purchasing impulses are resistible, but people often fail to resist them since the outcome depends on a variety of situational and inner forces.

Muraven and Baumeister (2000) define self-control as "an exertion of control over the self by the self." They propose the ego-depletion theory which suggests that exerting self-control consumes a limited resource which can ultimately lead to breakdowns in self-control. Their model emphasizes that each person has a limited amount of self-control strength which can be depleted, and using self-control efforts for 
one goal will reduce the resources available for self-control in other goals. For example, people in a depletion state are more likely to yield to temptations and buy impulsively.

In order to measure self-control, Tangney, Baumeister and Boone (2004) develop a 36-item self-control scale which covers all the spheres of self-control failure in their literature review. They also provide evidence about the psychological benefits and advantages of self-control. Their self-control scale is positively correlated with achievement and task performance, impulse control, psychological adjustment, interpersonal relationships, moral emotions, and related personality features. Their selfcontrol scale shows good internal consistency and retest reliability. By conducting exploratory factor analysis, they also construct a 13 -item brief self-control scale, which has been used to measure self-control in other studies (Redden \& Haws, 2013).

\subsubsection{Self-control in economics}

In the economics literature, the self-control problem focuses on the inconsistent time preferences in the intertemporal choice, and deals with the conflict between one farsighted self and one (or a series of) myopic self within each person (Frederick, Loewenstein, \& O'Donoghue, 2002; Schelling, 1984; Thaler \& Shefrin, 1981; Winston, 1980).

As one of the earliest studies to explore self-control from an economic perspective, Strotz (1956) implicitly defines self-control as "the deliberate regimenting of one's future economic behavior even at a cost". For a person who has to choose consumption plans for future times by maximizing his plan's utility evaluated at the 
current moment, the problem of interest is whether he will abide by the plan at later dates. The model shows that if the discount function is not exponential with a constant exponent, the decision maker should learn to distrust his future behavior and limit the future self's choices.

Following the early study by Strotz (1956), economists have devoted many efforts to understand the self-control problem in people's behaviors. Thaler and Shefrin (1981) view the decision-maker as an organization that consists of a planner and a series of doers. The planner cares about the life-time utility, but the doer at each period is myopic and only cares about the current period, which results in a conflict between longrun and short-run preferences. They point out the necessity to adopt a multiple-self model to study the self-control problem and provide a framework for further research. Shefrin and Thaler (1988) integrate their earlier self-control model into the life-cycle theory, and suggest that the term "self-control" contains three elements "internal conflict, temptation and willpower" in the trade-off between immediate gratification and long-run benefits. The concept of willpower can be understood as the efforts of the long-term planner to constrain the behavior of the myopic doer. By creating a willpower effort variable, their model illustrates how willpower determines the self-control result in the conflict between the planner and the doer.

Gul and Pesendorfer (2001) introduce a two-period model of self-control to show that a preference for commitment can come from a desire to avoid temptation. They propose to measure the cost of self-control by using the gap between the most tempting choice and the actual choice. The optimal choice is a compromise between the cost of 
self-control and the utility with commitment. Since the presence of temptation always reduces utility, their model suggests that removing the temptation can make individual better off. Gul and Pesendorfer (2004) extend their two-period model of self-control to an infinite horizon choice problem under uncertainty. They apply the infinite-period model to study a deterministic exchange economy and the existence of a competitive equilibrium, as well as applications in macroeconomics and financial economics.

Fudenberg and Levine (2006) develop a more general dual-self model of impulse control, and show that the strategy profile of the long-run and short-run selves is equivalent to a reduced form optimization problem. Specifically, they apply their general dual-self model into the savings problem, and this study will extend their simple saving model to study the interaction of self-control and professional financial advice on savings behaviors. Fudenberg and Levine (2012) extend the standard dual-self model of selfcontrol to deal with the excess sensitivity to the timing of decisions by allowing short-run selves to live more than one period. When short-run selves are assumed to live only one period, the cost function of self-control depends on the difference between the best forgone utility and the chosen utility. When short-run selves are assumed to live more than one period, the cost function of self-control depends on the difference between the average present value of best forgone utilities and the chosen utility. Moreover, they assume costly and limited cognitive resources for self-control and introduce a cognitive resource variable in order to track changes in the marginal cost of self-control.

About the measurement of self-control ability, economic studies make use of hypothetical choices in imagined choice questions. In Thaler (1981), subjects are asked 
how much money they would get at various future dates in place of a fixed immediate reward in order to measure the implied discount rates. It is assumed that the extent of the over-weighting towards the present can reflect the degree of subjects' self-control problem. However, subjects who choose the immediate reward may not consume all the reward today, and other factors such as uncertainty about future rewards may be the main reason behind choices. In response to that criticism, Ameriks et al. (2007) use a hypothetical choice scenario to ask people whether they will be tempted to deviate from their earlier ideal decision, and whether their actual choice will deviate from the deal. Applying the definition of self-control cost in Gul and Pesendorfer (2001), they assume that the difference between the expected actual choice and the reported ideal choice measure potential self-control problems.

With the method of factor analysis, DellaVigna and Paserman (2006) create an aggregate measure of impatience by using various indicators of self-control problems, which include NLSY assessment of impatience, having life insurance, having a bank account, smoking, binge drinking, use of contraceptives, and participation in vocational clubs. Factor analysis has been widely used in psychological research (Fabrigar, Wegener, MacCallum, \& Strahan, 1999; Floyd \& Widaman, 1995). Some recent economic studies have suggested making use of factor analysis to capture latent unobserved variables, such as some personality traits (Borghans, Duckworth, Heckman, \& Ter Weel, 2008, Kaplan, Klebanov, \& Sorensen, 2012). This study will follow the method in DellaVigna and Paserman (2006) to gauge individual differences in selfcontrol. 


\subsection{Professional financial advice}

Until now, the field of professional financial advice has not been well defined, and there are various definitions of financial advice in the existing literature. Roughly speaking, there are four types of professional financial advisors: technical experts, transactional agents, financial counselors, and financial coaches (Collins, 2010). Professional financial advice from technical experts has been studied by economists in the economics of information (Stigler, 1961), but the empirical evidence of technical experts is still limited in the literature (Bluethgen, Gintschel, Hackethal, \& Müller, 2008). The recent papers about transactional agents focus on the regulations for brokers and advisors due to the conflicts of interests (Krausz \& Paroush, 2002). In the literature about financial counseling, many applied studies examine the impact of financial counseling but there is a lack of theoretical frameworks about how financial counseling affects outcomes (Collins, 2010). Financial coaching remains as the least studied area, except some literature in psychology (Palmer \& Whybrow, 2007). In this study, professional financial advisor is defined as the third-party professional services provider with whom households discuss financial matters, and can be any type of financial advisors since the data do not distinguish them in the survey.

\subsubsection{Use of professional financial advice}

In the literature about financial advice, early studies focus on identifying factors that predict the use of professional financial advice (Elmerick, Montalto, \& Fox, 2002; Grable \& Joo, 1999; Lin \& Lee, 2004). 
Grable and Joo (1999) propose a five-stage model to conceptualize the decisions of whether and from whom to seek advice (e.g. professional advice or non professional advice from relatives, friends and colleagues). They find that behavioral variables such as financial management practices and psychological variables such as risk tolerance are at least as important as some demographic and economic variables in the choice of seeking professional financial help. By using the 1998 Retirement Confidence Survey (RCS), Joo and Grable (2001) find that female, income, positive financial behavior, proactive retirement attitude and high risk tolerance increase the likelihood to use professional financial advice, while characteristics such as age, race, marital status, and household size do not have significant effects. Under the framework of the five-stage model, Marsden et al. (2011) find that individuals' advice-seeking behavior is influenced by financial knowledge, risk tolerance, characteristics of retirement plan, and socio-demographic and economic characteristics.

Black, Ciccotello, and Skipper (2002) propose the planner model and the specialist model as two delivery models of personal financial planning services. In the planner model, the financial advisor acts as an intermediary between the individual and the specialist advisors. In the specialist model, the individual or household takes the responsibility to coordinate and work with advisor specialists in each area. The main difference between the two models is about who acts as the coordinator, the household in the specialist model or the financial planner in the planner model. Based on these two delivery models, Elmerick et al. (2002) assume that the planner model applies for households who use the advice for the comprehensive financial activities, and the 
specialist model applies for households who use the advice for credit and borrowing only, or advice for saving and investing only. Using the SCF data, Elmerick et al. (2002) find that factors such as age, education, race, marital status, household income, household financial assets, and the debt-to-income ratios, are related with households' likelihood to seek professional financial advice. They also compare the different effects of household socio-demographic and financial characteristics by the category of use. For example, when household income and financial assets are controlled, they find that the level of household net worth is positively related to the likelihood of using advice for the comprehensive financial activities, but does not affect the likelihood of using advice for credit and borrowing only, or for saving and investing only.

Lin and Lee (2004) examine factors that influence the extent of households' information search in making investment decisions, by considering a variety of information sources, such as the Internet, friends/family, and professional financial advisors. They find that the probability of using professional financial advice is related with socio-demographic characteristics and psychological factors such as age, education, income, subjective knowledge, and risk tolerance. However, due to the cross-sectional feature in datasets, those studies can only examine the association between household characteristics and the use of financial advice, but cannot establish the direction of causality in the financial advice-seeking behavior (Marsden et al., 2011).

Tang and Lachance (2012) use data from the National Financial Capability Study (NFCS) to examine the determinants and benefits of seeking professional financial advice, with an emphasis on the low-income households. In their study, low-income 
households are defined as people with an annual household income lower than $\$ 25,000$, and high-income households are defined as people with an annual household income higher than $\$ 75,000$. They show that these two income groups have different financial advice-seeking considerations. They also provide some evidence about the larger positive effect of professional financial advice on low-income group than the high-income group. They distinguish four types of financial advice: savings/investment advice, tax advice, insurance advice, and debt advice. They find that the savings/investment advice is the most demanded advice by high-income consumers, while low-income consumers use more insurance advice than savings/investment advice.

\subsubsection{Professional financial advice and retirement planning}

The previous literature about the impacts of professional financial advice is mainly on long-term aspects of financial planning, such as retirement planning (Lusardi \& Mitchelli, 2007; Marsden et al., 2011), and investment behaviors (Bluethgen et al., 2008; Hackethal, Haliassos, \& Jappelli, 2012; Kramer, 2012).

The added value of professional financial advice in retirement planning and preparedness is an important thread in the literature. Using the 2004 Survey of Consumer Finances, Finke, Huston, and Waller (2009) find that the use of financial planners can increase the likelihood of holding adequate life insurance protection, which is an essential component of a comprehensive financial plan. Smith, Finke, and Huston (2012) identify a positive relationship between using financial planners and owning a Roth IRA. 
By using an online survey participated by benefits-eligible employees of a large university, Marsden et al. (2011) study the impact of financial advice on retirement planning by comparing people who have and have not met a professional financial advisor within the last two years. Due to the potential problem of self-selection and endogeneity in cross-sectional data, Marsden et al. (2011) adopt a propensity score approach by creating matches between the treatment group (people who have met a professional financial advisor) and the control group (people who have not met a professional financial advisor). They compare a variety of retirement planning activities and outcomes, such as goal-related planning activities, plan implementation outcomes, and long-term financial outcomes, between people who have and have not met a financial advisor. They find that people who have met with a financial advisor report significantly better retirement planning and implementing in many aspects than people who have not. Even after controlling for the self-selection in advice-seeking behavior, they still find a number of statistically significant differences in the matched samples. About retirement planning, they conclude that professional financial advisors can encourage people to calculate their retirement needs and set financial goals, use supplemental retirement accounts, accumulate emergency funds, and feel confident about their future.

Cummings and James (2013) examine the influence of professional financial advisors on financial decisions among the population over the age of 60 . They use the data from the Study of Assets of Health Dynamics Among the Oldest Old (AHEAD) in 1993 and 1995, which has been merged with the Health and Retirement Study (HRS) since 1998. They find that there is a significant positive relationship between using 
professional financial advice in 1993 and subsequent net worth from 1993 to 2008. However, given the uncertainty about household preferences in seeking professional financial advice, they cannot exclude the possibility that some unobserved differences result in their findings.

\subsubsection{Professional financial advice and investment behavior}

In terms of investment behavior, Bluethgen et al. (2008) use an administrative dataset on the investment accounts from January 2003 to October 2005. They find that customers who are female, older, wealthier and risk averse tend to seek financial advisory service. They conclude that professional financial advice has a significant impact on household investment behavior such as enhancing portfolio diversification.

Kramer (2012) compares the portfolio performance of advised and non-advised Dutch investors and aims to provide some evidence of the added value of financial advice. He finds that advised investors have better diversified portfolios and significantly less idiosyncratic risk than self-directed investors, although the differences are quite small. Moreover, an analysis of investors who switched from non-advised to advice confirms that professional advisors can help investors significantly improve portfolio diversification. However, he finds no significant effects of financial advice on portfolio returns by comparing advised and non-advised investors, and by comparing portfolio returns before and after using professional financial advice.

Hackethal et al. (2012) use datasets from a large brokerage and bank to study how advised investors perform compared to non-advised investors. They find that financial 
advisors have negative effects on portfolio returns and risk-return profiles, as measured by the Sharpe ratio, and suggest that many financial advisors collect more in fees and commissions than adding monetary value to advised accounts.

Mullainathan et al. (2012) conduct an audit study to examine whether financial advisors provides suggestions in line with clients' interests. They suggest that the market of financial advisors who are paid based on the fees they generate is very imperfect, since such advisors may exaggerate clients' existing biases for their own interests. With concerns about conflicts of interests, some studies about transactional brokers cannot find that brokers provide substantial tangible benefits to their clients in mutual funds selection and transactions (Krausz \& Paroush, 2002; Bergstresser, Chalmers, \& Tufano, 2009). Using a panel dataset on the Canadian financial advisory industry, a recent study finds that financial advisors fail to add value through their investment suggestions, compared to passive investment benchmarks (Foerster, Linnainmaa, Melzer, \& Previtero, 2014). Moreover, they find that households who consult financial advisors do save more in their life. However, they do not explore the mechanism behind this phenomenon given some limitations in their industry data. My study finds similar phenomena about the relationship between professional financial advice and household savings, and I further examine this relationship by using a Germany panel dataset with rich information about households. 


\section{Chapter 3: Theoretical framework and hypothesis}

This chapter will introduce the theoretical framework and derive three research

hypotheses. In section 3.1, the first subsection will specify how professional financial advice affects self-control ability in the planning and implementing stages. The second subsection will discuss the general dual-self model of self-control and then the simple savings model in Fudenberg and Levine (2006). Section 3.2 will derive three hypotheses from the model and will conclude with a discussion of model selection.

\subsection{Theoretical framework}

\subsubsection{Impact of professional financial advice}

Professional financial advice may influence household financial behaviors in a variety of ways, such as developing investment strategies and implementing financial plans (Marsden et al., 2011).

First, professional financial advisors can help households improve their financial knowledge and make informed decisions. McKenzie and Liersch (2011) find that people tend to underestimate the wealth accumulation in saving accounts, since they confuse exponential growth with linear growth. They suggest that this fundamental 
misunderstanding of saving growth is an important reason behind the lack of retirement savings. Professional financial advisors can motivate their clients to save by explaining the compounding of interests and the exponential growth of savings. Moreover, professional financial advisors can introduce relatively high-return investment devices or retirement accounts with tax benefits to their clients who only use regular saving accounts.

Second, professional financial advisors can help clients analyze their current financial situations, estimate their future financial needs and make comprehensive financial plans. For instance, Hershfield et al. (2011) use technology to show each subject a vivid image of his/her elderly self under different saving plans and the resulting future financial situations in experiments. They find that vivid representations of future selves can make subjects become future-oriented and save for their long-run financial plans. Similarly, professional financial advisors may make clients future-oriented by analyzing their financial situation and envisioning their future financial needs.

In implementing financial plans, financial advisors may help people who have inconsistent time preference realize their potential self-control problems, and may help clients strengthen self-control in financial behaviors through several channels.

First, for people with self-control problems, professional financial advisors can recommend financial commitment devices to help them implement their financial plans by limiting their future choices. For example, financial advisors may suggest clients to allocate more funds to illiquid assets or commitment accounts which restrict or even disallow early withdrawals. Financial advisors may convince clients to commit to certain 
automatic saving plans, which can minimize future losses due to possible self-control failure.

Second, if self-control strength is a limited psychological resource as suggested by Muraven and Baumeister (2000), seeking professional financial advice can help people save self-control resources in making plans and have more resources for selfcontrol in implementing plans. For example, financial advisors can help households who lack confidence in financial management make comprehensive long-run financial plans and get peace-of-mind in the implementation stage. In this way, these households achieve better self-control in implementing plans.

Third, financial advisors may provide some help in monitoring by encouraging budgeting or the usage of automatic reminding messages provided by banks. In addition, meeting an advisor provides incentives as well as reminders to review accounts statements (Baumeister, 2002).

\subsubsection{Theoretical model}

Given the above influences of professional financial advice on self-control, this research applies the dual-self model of impulse control in Fudenberg and Levine (2006) to study the interaction of professional financial advice and self-control on household savings. This model is similar in spirit to the planner-doer model in Thaler and Shefrin (1981), which assumes the interaction of the patient long-run self (the planner) and a sequence of myopic short-run selves (the doers) determines the overall behavior. 
Compared with traditional economic models, the advantage of the dual-self model is that it views self-control as a rational choice of the long-run self.

In the general dual-self model in Fudenberg and Levine (2006), the utility function $u(y, r, a)$ of the short-run self has three components: $y$ represents the state; $r$ represents the self-control actions of the long-run self, and $a$ represents the action of the short-run self. $Y$ represents the space of states; $A$ represents the set of actions for the short-run selves, and $R$ represents the set of self-control actions for the long-run self and the point $0 \in R$ means no self-control. $H$ represents the space of history, which consists of the past states and actions, $h_{t}=\left(y_{1}, r_{1}, a_{1}, \ldots, y_{t}, r_{t}, a_{t}\right)$ or the null history 0 . The selfcontrol action $(r)$ of the long-run self can influence the utility function $u(y, r, a)$ of the short-run self, and therefore affects the actions ( $a$ ) chosen by the short-run selves. After observing the self-control action of the long-run self, each short-run self chooses his action and lives only one period.

The interactions between the long-run self and the sequence of short-run selves can be treated as a game between them. In this game, short-run perfect Nash equilibrium is defined as a strategy profile in which the short run self optimizes under every history, and the long-run self predicts the short-run self's action and makes a plan accordingly.

Under four assumptions about self-control and utility function, Fudenberg and Levine (2006) show that the short-run (SR) perfect Nash equilibrium in the game between the long-run self and the short-run selves has an equivalent solution in a reduced form optimization problem, which has only one player and omits the self-control 
variable. This theorem simplifies the problem to find the optimal actions of the short-run selves.

Moreover, Fudenberg and Levine (2006) applied their general dual-self model to study an infinitely-lived consumer's savings decisions. In this simple savings model, the action $a \in[0,1]$ represents the savings rate, and the state $y \in[0,+\infty)$ represents wealth. Savings $\left(a_{t} y_{t}\right)$ are invested and the wealth in next period is $y_{t+1}=R a_{t} y_{t}$. Assume that there is no borrowing and no other source of income.

The linear self-control cost is assumed to be proportional to the difference between the utility of the best foregone option $\max _{a^{\prime}} u\left(y, 0, a^{\prime}\right)$ and the utility of the chosen option $u(y, 0, a)$. The self-control cost parameter is represented by $\gamma$, which is in the range of $[0,1]$.

$$
C(y, a) \equiv \gamma \cdot\left[\max _{a^{\prime}} u\left(y, 0, a^{\prime}\right)-u(y, 0, a)\right]
$$

Assume that the short-run self has logarithmic utility function in each period,

$$
u(y, 0, a)=\log [(1-a) y]
$$

The temptation to the short-run self is to spend all available wealth on consumption, which means that $\max _{a^{\prime}} u\left(y, 0, a^{\prime}\right)=\log (y)$. Therefore, the self-control cost is

$$
C(y, a)=\gamma \cdot[\log (y)-\log (1-a) y]
$$


Applying the theorem about the equivalence of the dual-self's strategy profile to the reduced form, the long-run self's reduced-form optimization problem can be written as below:

$$
\begin{aligned}
& \operatorname{Max}_{\left\{a_{1}, a_{2}, \ldots\right\}} U_{R F}=\sum_{t=1}^{\infty} \delta^{t-1}\left[u\left(y_{t}, 0, a_{t}\right)-C\left(y_{t}, a_{t}\right)\right] \\
& \text { s.t. } \quad y_{t}=R a_{t-1} y_{t-1} \quad t=1,2, \ldots
\end{aligned}
$$

The parameter $\delta$ represents the discount factor. The parameter $\mathrm{R}$ is the sum of one and the interest rate. The symbol $U_{R F}$ represents the discounted life-time utility in the reduced-form optimization problem. Fudenberg and Levine (2006) show that this optimization problem has a unique solution, which is a constant savings rate strictly between zero and one: $a_{t}=a \in(0,1), \forall t$. Therefore, the optimization problem can be simplified as below.

$$
\begin{gathered}
\operatorname{Max}_{\left\{a_{1}, a_{2}, \ldots\right\}} U_{R F}=\sum_{t=1}^{\infty} \delta^{t-1}\left[u\left(y_{t}, 0, a\right)-C\left(y_{t}, a\right)\right] \\
\text { s.t. } \quad y_{t}=\operatorname{Ray}_{t-1}
\end{gathered}
$$

By plugging in the utility function and the self-control cost function, the optimization problem becomes:

$$
\begin{array}{cl}
\operatorname{Max}_{\left\{a_{1}, a_{2}, \ldots\right\}} U_{R F} & =\sum_{t=1}^{\infty} \delta^{t-1}\left[(1+\gamma) \cdot \log (1-a) y_{t}-\gamma \cdot \log \left(y_{t}\right)\right] \\
\text { s.t. } & y_{t}=(R a)^{t-1} \cdot y_{1}
\end{array}
$$


Then, the objective function can be calculated as below.

$$
\begin{aligned}
U_{R F} & =\sum_{t=1}^{\infty} \delta^{t-1}\left[(1+\gamma) \log (1-a)+\log \left(y_{1}\right)\right]+\sum_{t=1}^{\infty} \delta^{t-1}(t-1) \log (R a) \\
& =\frac{(1+\gamma) \cdot \log (1-a)+\log \left(y_{1}\right)}{1-\delta}+\frac{\delta \cdot \log (R a)}{(1-\delta)^{2}}
\end{aligned}
$$

Taking the first-order derivative, the first-order optimal condition is as below.

$$
\frac{\partial U_{R F}}{\partial a}=-\frac{1+\gamma}{(1-\delta)(1-a)}+\frac{\delta}{a(1-\delta)^{2}}=0
$$

Therefore, the constant optimal savings rate is $a=\frac{\delta}{1+(1-\delta) \cdot \gamma}$, which is strictly between zero and one. Fudenberg and Levine (2006) derived this optimal saving rate in their simple saving model. I will use their simple saving model as the theoretical framework, and extend it to study the role of professional financial advice in the decision of optimal saving rate.

\subsection{Research hypotheses}

Given the same utility function, a lower value of $\gamma$ represents a lower self-control cost, and equivalently means higher self-control ability. It is easy to show that the optimal savings rate $(a)$ has a negative relationship with the self-control cost parameter $(\gamma)$. That is, when $\gamma_{1}<\gamma_{2}$, I can show that $a_{1}>a_{2}$.

Hypothesis 1: People with higher levels of self-control save more than those with lower levels of self-control. 
I extend this simple saving model to consider the role of professional financial advice in reducing self-control cost. Assume that professional financial advice (PFA) can reduce the self-control cost parameter $(\gamma)$, since advisors can help clients reduce selfcontrol costs by providing commitment devices or directly managing clients' assets. Here, PFA $\in[0,1]$ is assumed to be a continuous variable about the extent that a household will get and follow the professional financial advice. The case of PFA=0 can represent two situations: (1) a household does not seek professional financial advice; (2) a household gets professional financial advice but does not follow it at all. Given the reasons that professional financial advisors can help strengthen self-control, I assume that there is a negative relationship between PFA and the self-control cost parameter $(\gamma)$, that is $\frac{\partial \gamma(P F A)}{\partial P F A}<0$. Under this assumption, I derive that

$$
\frac{\partial a}{\partial P F A}=\frac{\partial a}{\partial \gamma} \cdot \frac{\partial \gamma}{\partial P F A}=-\frac{(1-\delta) \cdot \delta}{(1+(1-\delta) \gamma)^{2}} \cdot \frac{\partial \gamma(P F A)}{\partial P F A}>0
$$

This means that the effect of PFA on savings rate is positive.

Hypothesis 2: Holding other conditions unchanged, the effect of professional financial advice is positive on people's saving behaviors.

Before getting professional financial advice $(P F A=0)$, assume that client 1 have lower self-control costs than client 2 , that is $\gamma_{1}<\gamma_{2}$ with $\gamma_{1}=\gamma_{1}(\mathrm{PFA}=0)$ and $\gamma_{2}=\gamma_{2}(P F A=0)$. After getting professional financial advice $(P F A>0)$, both clients will have lower self-control costs with help from financial advisors. For example, professional financial advisors may recommend automatic saving accounts to clients. 
This kind of suggestions can help clients improve self-control in financial management. Moreover, the relationship between their new self-control costs will have three possible situations: first, client 1 has the same self-control cost with client 2; second, client 1 has higher self-control cost than client 2; third, client 1 still has lower self-control cost than client 2. In the first situation, two clients have the same self-control costs, that is $\gamma=$ $\gamma_{1}(P F A>0)=\gamma_{2}(P F A>0)$. From the formula of the optimal saving rate, client 1 has higher saving rate than client 2 , that is $a_{1}>a_{2}$ before getting PFA. However, after getting PFA, their savings rate will become the same. Therefore, I show that $\Delta a_{1}<\Delta a_{2}$. The same results can be derived in the rest two situations. Please turn to Appendix to find the proof.

Hypothesis 3: The effect of professional financial advice on savings is larger for people with lower levels of self-control than for those with higher levels of self-control.

The alternative theoretical framework for this study is quasi-hyperbolic models with a long-run time preference and a short-run time preference. Dual-self models emphasize the mental structure within each person, and quasi-hyperbolic models emphasize the form of discounting function that can better fit data about actual behavior. Therefore, the quasi-hyperbolic models have the advantage of parsimony in modeling intertemporal problems, and the dual-self models have the advantage to provide natural and direct explanations for some phenomena. Fudenberg and Levine (2006) suggest that both dual-self models and quasi-hyperbolic models can provide similar predictions in most applications. These two types of models have many similarities in explaining the inconsistent time preferences with different emphases. For example, both the dual-self 
model and the quasi-hyperbolic model can explain the problem of procrastination and delay (O'Donoghue \& Rabin, 1999, 2001; Funderberg \& Levine, 2006) and the adoption of commitment devices (Laibson, 1997; Fudenberg \& Levine, 2006).

Furthermore, Borghans et al. (2008) point out that time preference in economics is likely to be a multidimensional concept. For example, time preference may contain different components, such as "the inability to inhibit an impulse, the tendency not to consider or imagine the future, comfort with ambiguity, and the like." In the literature, there is no clear distinction between three concepts: short-run time preference, selfcontrol and short-run impatience. In quasi-hyperbolic discounting models, the short-run impatience parameter $\beta$ is often explained as the inability to inhibit an impulse, or equivalently self-control (Laibson et al.,1998, Mastrobuoni \& Weinberg 2009, DellaVigna \& Paserman 2006). I should note that the quasi-hyperbolic model can analogously explain the effect of professional financial advice on saving behaviors, by assuming that the short-run discounting parameter $\beta$ decreases with professional financial advice. 


\section{Chapter 4. Research design and Methodology}

This chapter presents information on the SAVE panel used in this research, the sample, the definition and measurement of variables, and the research methodology. Section 4.1 describes the general information of the SAVE panel and some methodological issues such as interview mode, and the multiple imputation procedure. Section 4.2 provides details on the definition and measurement of dependent and independent variables. Section 4.3 discusses the research methodology and the model selection procedure in this research.

\subsection{Data and sample}

\subsubsection{Data}

This study uses data from the 2005-2009 SAVE. The longitudinal dataset SAVE is being collected by the Munich Center for the Economics of Aging (MEA) at the Max Planck Institute for Social Law and Social Policy in Germany. This dataset is representative of the German residential population. The first wave of the SAVE study was initiated in the summer of 2001. The second wave was conducted in the summer of 2003. Since 2005, this panel has been surveyed on an annual basis. The average length of 
the interview is about 45 minutes. A stable set of questions have been asked in every wave, and some complementary questions about up-to-date topics have been asked in one wave. The core questionnaire contains six parts, as summarized in Table 4.1.

Table 4.1: Structure of the SAVE questionnaire

Part 1 Introduction; determining which person will be surveyed in the household

Part 2 Basic socio-economic data of the household; health questions (since 2005)

Part 3 Qualitative questions on saving behavior, income and wealth

Part 4 Quantitative questions on income and wealth

Part 5 Psychological and social determinants of saving behavior

Part 6 Conclusion: comments on the interview

Source: Börsch-Supan, Coppola, Essig, Eymann, \& Schunk, (2008).

The first wave in 2001 mainly used a Quota Sample as an experiment to find the optimal choice among different versions of interview mode. This Quota Sample has been discontinued since 2005. Among different interview modes, the chosen mode is a mixedmode interview strategy: the interviewer administers some questions in person and drops off the self-administered paper and pencil questionnaire (P\&P) to be answered in private, and picks up the drop-off questionnaire later. This interview mode is found to help reduce the rate of non-response to the critical and sensitive financial questions and improve the accuracy of respondents' answers. In order to improve accuracy, respondents are asked to 
indicate whether they have checked their documents or estimated the information when answering questions about financial assets.

Besides the Quota Sample, there are two main subsamples with different sampling schemes. The first is the Random Sample, which is drawn by random sampling scheme from the community-based registers of the German population (Börsch-Supan et al., 2008). The second subsample is the Access Panel, which is a standing panel of households surveyed regularly and operated by the company TNS Infratest TPI (Test Panel Institute, Wetzlar). The Random Sample started in 2003 and refreshed in 2005. The Access Panel started in 2001 and refreshed in 2006. The problem of sample attrition also leads to change in sample size of each wave. For example, in 2006, there are 1,636 newly-added households and 467 lost households. The detailed changes in the sample structure are shown in Figure 4.1. 
Figure 4.1: Sample structure of SAVE 2001-2009

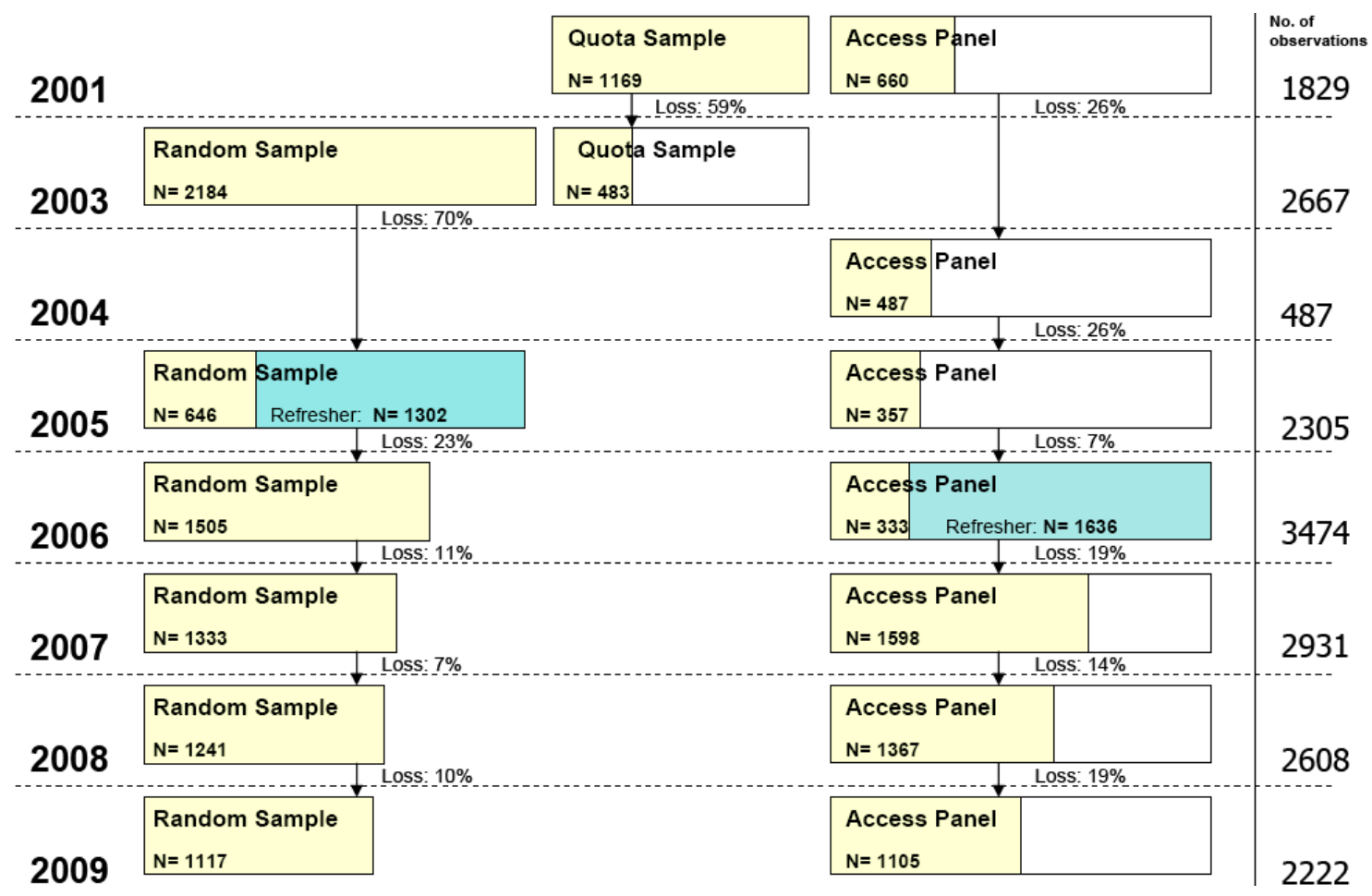

Source: The Munich Center for the Economics of Aging (MEA)

Similar with other household finance surveys, the SAVE survey has the problem of item non-response, mainly with sensitive financial variables such as income and wealth. If item non-responses are not random among respondents, deleting observations with missing values will lead to biased results (Montalto \& Sung, 1996). In order to reduce non-response bias, SAVE implements a Markov Chain Monte Carlo multiple imputation procedure to assign plausible values to missing variables (Schunk, 2008). The purpose of multiple imputation is to provide the most likely range of missing data. 
The Markov Chain Monte Carlo multiple imputation procedure creates five multiple imputed datasets as well as one indicator dataset in each wave. With the logical panel imputation, the indicator dataset uses " 2 " to signal a logically imputed value by using the panel information, " 1 " to signal a stochastically imputed missing value, and " 0 " to signal an observed value. The logical panel imputation only needs the mild assumption that respondents provide true answers consistently over the years. For example, the information of currently smoking in 2005 can be used to impute the missing variable about ever regularly smoking in 2006. Otherwise, stochastic imputation procedures are used for the remaining missing variables.

The advantage of multiple imputations (MI) estimation is to make use of the information from all five implicates and incorporate imputation variability (Rubin, 1987). The procedure of multiple imputation estimation ${ }^{1}$ is like this. The first step is to analyze each of the five imputed datasets. The second step is to combine the results and make inferences from five estimates. The MI point estimate of each regression parameter is the average of the five estimates from the five imputed datasets. The associated variance is a linear combination of the within imputation sampling variance and the between imputations variance. The within imputation sampling variance is the average of the five variance estimates, and the between imputation variance is the variance of the point parameter estimates. Since this total variance is larger than each variance, the levels of significance are generally more stringent by analyzing MI datasets. More details of the multiple imputation estimation used in this study will be provided in Section 5.2.

\footnotetext{
${ }^{1}$ Multiple imputation estimation is also referred as repeated-imputation inference (RII).
} 


\subsubsection{Sample}

The SAVE survey contains rich information on households' socio-demographic characteristics, health behaviors, saving behaviors, asset choices and holdings, and psycho-social determinants of savings behaviors. In each year, the survey asks respondents about their financial behaviors and their financial situations. From 2005 to 2009, three questions about advice-seeking behaviors, with an emphasis on professional financial advice, have been asked in the SAVE panel. This offers a unique opportunity to investigate the effect of professional financial advice on household saving behaviors over time, because this timely-released data also includes a broad variety of explanatory variables.

This study will use five waves in this panel dataset from 2005 to 2009, whose sample sizes are 2,305, 3,474, 2,931, 2,608 and 2,222, respectively. In each wave, there are about one-third households who consult professional financial advisors in banks, insurance companies and financial service providers. Relying on data from the 2010 Survey of Consumer Finances (SCF), there are about 43.2\% American households who seek professional financial advice from financial planners, bankers, brokers, accountants, and lawyers ${ }^{2}$. Therefore, it is more popular among American households to seek professional financial advice than German households.

\footnotetext{
${ }^{2}$ I want to thank Dr. Sherman Hanna for providing this information.
} 


\subsection{Measurement of variables}

\subsubsection{Dependent variable}

This study will use several dependent variables about saving behaviors and financial outcomes to measure the effect of professional financial advice on household financial behaviors. The literature suggests that the impact of self-control problems on wealth accumulation is different between liquid and illiquid assets (Ameriks et al., 2007). This study can test whether the effect of self-control is different on liquid and illiquid assets. I will also examine the impacts of professional financial advice on household assets with different liquidity.

Professional financial advice may influence household financial behaviors in both the short run and the long run. To examine the impact of financial advice on short-run financial behaviors, I will use annual investment savings out of windfall, total annual savings, and annual own contribution to pensions as dependent variables. To examine the impact of financial advice on long-run wealth accumulation, I will use emergency-funds, total illiquid assets, total financial assets, total assets and total loans as dependent variables. Due to the skewed distribution, those variables will be transformed by using the natural log function, and the zero will be coded as zero.

Annual investment savings out of windfall

In permanent income hypothesis $(\mathrm{PIH})$, measured income and measured consumption have two components: a permanent part which is anticipated and planned, 
and a transitory part which is unexpected windfall income. The SAVE survey asks respondents whether they have some windfall income in the previous year as well as the amounts of each type of windfall income. Then, respondents are asked how they deal with their windfall income among 10 categories of usage. Four categories are related with investment and savings: (1) savings investment with a clearly defined purpose (e.g. in the form of a building society savings agreement, whole life insurance policy, and private pension plan); (2) other financial investment, e.g. purchase of shares or securities; (3) purchase of a flat or house; (4) repayment of debts. The annual investment savings out of windfall is created by summing up the amounts of these four categories.

Total annual savings

In each wave, respondents are asked to provide the figure of their household's total annual savings in the previous year. Due to the skewed distribution, the total annual savings will be transformed by using the natural log function. If one household has not saved anything or have dis-saved, this variable will be coded as zero.

Own contribution to pension

The SAVE survey asks the respondents their private or occupational pension contracts, the value at the end of the previous year, the value of their employer's contribution, and the value of their own monthly contributions. The value of their own monthly contributions will be used as the dependent variable, because pension is an important component of household retirement saving. Relying on a cross-sectional 
dataset, Marsden et al. (2011) find that getting professional financial advice is related to retirement planning and preparation. My study will examine whether getting professional financial advice is related with households' own contribution to their retirement accounts.

\section{Emergency-funds}

The emergency funds are one type of savings that households prepare for unforeseen circumstances. Marsden et al. (2011) find that people who have consulted a professional financial advisor have significantly higher levels of emergency funds and have better emergency fund adequacy. They suggest that the emergency fund adequacy indicates financial planning. They use a cross-section dataset to compare people who have met and have not met a professional financial advisor. My study will examine the effect of professional financial advice on emergency funds over time. In the SAVE survey, the respondents are asked to provide a figure they save for emergencies. If households do not have emergency funds, this variable will be coded as zero.

\section{Total financial assets}

The respondents are asked whether they own six types of assets: savings investments, building society savings agreements, bonds, shares and real-estate funds, and other assets. For each type of owned assets, the questionnaire also asks about their balance in the last month of the previous year. In order to know whether the figures are accurate, respondents are asked to indicate whether they checked documents for answering these questions. The total amount of financial assets is created by summing up 
all types of financial assets. If households do not have financial assets, this variable will be coded as zero.

Total illiquid assets

Illiquid assets are often viewed as natural commitment devices for people with self-control problem (Angeletos, Laibson, Repetto, Tobacman, \& Weinberg, 2001). Therefore, it is expected that households' illiquid assets are related with self-control ability and may be affected by professional financial advice. The total amount of illiquid assets is the sum of house wealth, other real estate, pensions, business value, and other valuable items (such as jewelry and antiquities). If households do not have illiquid assets, this variable will be coded as zero.

Total assets

The amount of total assets is the sum of financial assets and illiquid assets. If households do not have any assets, this variable will be coded as zero.

Total loans

The respondents are asked whether they have any loans in five categories: building society loan, mortgage, consumer credit loan, family loan, and other loans. If respondents have any type of loans, they are also asked to provide a figure of loans at the end of the previous year in each category. The amount of total loans is the sum of all loans that have not been paid off. If households do not have any loans, this variable will be coded as zero. 


\subsubsection{Independent variable}

\subsubsection{Professional financial advice}

In the questionnaire, respondents are asked with whom they discuss financial matters with. The exact wording is:

Do you talk about financial topics with:

- relatives, who do not live in the same household

- friends

- colleagues

- neighbors

- financial advisors of banks, insurance companies or financial service providers.

- I do not talk with any of these persons about financial topics.

Respondents give "Yes/No" answers to each category. The question about whether households have sought professional financial advice will be used to create a dummy variable $P F A_{i t}$ for each household $i$ in each year $t$, which is equal to 1 if household $i$ has reported "Yes" in year $t, 0$ otherwise. For households who report to seek professional financial advice, there are two following questions about the frequency of advice-seeking and the self-reported extent to follow professional financial advice on a scale from 0 to 10 . 
Advices from relatives, friends, colleagues and neighbors are treated as nonprofessional financial advice. If respondents get any type of non-professional financial advice, the dummy variable of non-professional advice is coded to be 1 , and 0 otherwise.

Table 4.2 summarizes the frequency of advice-seeking behaviors in 2005-2009. More than half of households discuss financial matters with other people in each wave, and it is more common for households to get non-professional financial advice than professional financial advice. There are a substantial proportion of households who get both non-professional and professional financial advice. This is why the sum of households who get professional financial advice and households who get nonprofessional financial advice is larger than the number of households who get advice (any type). The sum of households who get advice and households who don't get advice is equal to the sample size in each wave.

Table 4.2: Frequency of advice-seeking in 2005-2009

\begin{tabular}{lccccc}
\hline \hline & 2005 & 2006 & 2007 & 2008 & 2009 \\
\hline Sample size & 2,305 & 3,474 & 2,931 & 2,608 & 2,222 \\
\# get professional advice & 641 & 1,318 & 972 & 913 & 778 \\
\# get non-professional advice & 981 & 1,626 & 1,216 & 1,103 & 913 \\
\# get advice (any type) & 1,336 & 2,338 & 1,781 & 1,672 & 1,373 \\
\# don't get advice & 969 & 1,136 & 1,150 & 936 & 849 \\
\hline
\end{tabular}

Source: Own calculation. 
In order to get a clear picture about the patterns of PFA-seeking behaviors in the 2005-2009, I create a five-digital string to track each household's PFA-seeking behaviors. The five-digital string uses the number "1" represents to get PFA in the corresponding year, the number "2" represents not to get PFA in the corresponding year, and the number " 3 " represents that the respondent becomes missing since that year. The first number of the string represents the PFA-seeking behavior in 2005, and the second number represents the behavior in 2006 , and so on.

For example, the string 21133 represent that the respondent don't get PFA in 2005, and then get PFA in 2006 and 2007, and then drops out the sample in 2008 and 2009. In the 2005-2009 panel, there are five types of patterns in PFA-seeking behaviors: (1) 591 respondents always get PFA only if they are in the sample; (2) 1,775 respondents never get PFA when they are in the sample; (3) 401 respondents change from not getting PFA to getting PFA in the sample; (4) 353 respondents change from getting PFA to not getting PFA in the sample; (5) 822 respondents have mixed patterns in their PFA-seeking behaviors in the sample.

\subsubsection{Measure of Self-Control}

People with lower levels of self-control are likely to be attracted by activities with immediate rewards and delayed costs. Differently, people with higher levels of selfcontrol may engage frequently in activities with delayed rewards and immediate costs. The information on several such types of behavior in the survey will be used to construct the aggregate measure of self-control. 
I make three similar identifying assumptions with DellaVigna and Paserman (2006). First, high measures of self-control are associated with high levels of self-control ability and low self-control cost. Under this assumption, I can use the created aggregate measure of self-control to proxy the unobserved self-control ability. Second, for each person, the self-control cost and the self-control ability are the same across different types of saving behaviors. This assumption guarantees that one person has only one measure of self-control in each year. Third, the self-control ability and the self-control cost may fluctuate over time due to outside or inside changes. For example, getting professional financial advice is assumed to be a reason for changes in self-control ability. This study will construct the measure of self-control for each household in each wave, by using corresponding information in each wave. Differently, DellaVigna and Paserman (2006) create only one aggregate measure of impatience that is measured before the occurrence of unemployment, though they admit that a long unemployment may change people's impatience. My study assumes that professional financial advice have an influence on the self-control cost and creates one aggregate measure of self-control in each wave. The variation in the aggregate measure of self-control can capture the fluctuation in selfcontrol over time.

I should note that three behavioral variables are imperfect proxies for the selfcontrol ability. The method of factor analysis may capture other common factor, such as economic resources.

\section{Saving Habit}


People with high levels of self-control have the ability to manage their finance better than others, such as saving more with certain budget (Romal \& Kaplan, 1995). Similar to the proxy of having a bank account in DellaVigna and Paserman (2006), I use a more informative ordinal variable about saving habit. Consumption can be temptations, and people need to exert self-control to form and keep good saving habit. Therefore, I assume that there is a positive relationship between self-control and saving habit.

The highest value $(=5)$ of this variable means that the respondent reports that "I/We save a fixed amount regularly, for instance in a savings account, a savings plan, in shares or a life insurance scheme." People with higher levels of self-control are expected to report this kind of saving habit. A value of 4 represents that "I/We put something aside each month, but I/We decide on the amount according to the financial circumstances." A value of 3 represents that "I/We put something aside when I have something left over to save." A value of 2 represents that "I/We do not save because I do not have enough scope financially to do so." The lowest value $(=1)$ of this variable means that the respondent reports that "I/We do not save because I would prefer to enjoy life now." People with lower levels of self-control are expected to report lower values in saving habit.

The correlation coefficient between saving habit and total annual savings is 0.109 . The group of households who report saving habit $=4$ have the highest average total annual savings among five groups of households. Similarly, the correlation coefficient is 0.084 between saving habit and total assets. The highest number of average total assets is from the group of households with saving habit=4. Moreover, the group of households who report saving habit $=1$ have much higher total assets than those with saving habit $=2$ or 3 . 


\section{Health Habit of Smoking}

The literature has focused on the association between time discounting rates and smoking behaviors, and empirical studies have provided mixed results. As a seminal study, Fuchs (1982) finds that people with lower time discounting rates are more likely to engage in healthy behavior, such as non-smoking. Scharff and Viscusi (2011) find that smokers have much higher rates of time preference than non-smokers in their samples of workers. Relying on questionnaire-based measures, psychology studies find that smokers are more impulsive than non-smokers, such as Mitchell (1999). In contrast, Khwaja, Silverman, \& Sloan, (2007) find no significant differences in revealed rates of time discounting between smokers and non-smokers. Their results indicate that measures of self-control are more closely related to smoking decision than short-run and long-run discount rates. Their findings suggest that smoking behavior can well capture problems of self-control, instead of time discount rates. Moreover, Hersch (2005) finds that smokers who plan to quit smoking are more likely to support regulatory restrictions in public areas, which can serve as a self-control mechanism. In this study, I use smoking behavior as a measure of self-control: cigarettes are temptation and people need to exert self-control to refrain from smoking. I create a dummy variable to indicate the current smoking behavior. If the head does not smoke currently, this variable is coded to be 1 , and 0 otherwise.

\section{Less Overdraw}


Stango and Zinman (2011) use survey questions to attract attention toward overdraft fees and find that spending control is associated with reducing overdrafts. Since households can exert self-control to avoid substantial overdraft fees, people with higher levels of self-control can be assumed that they will not use their accounts' overdraft facility. First, I construct a category variable "Overdraft" to indicate the frequency of overdraft: Overdraft $=2$ if respondents report that they often use the overdraft facility, or use more than 4 times per year; Overdraft=1 if respondents report that they seldom use it, or use 1-3 times per year; Overdraft $=0$ if respondents report that they don't have an overdraft facility, or have an overdraft facility but never use it. I create the variable "Less Overdraw" by using 2 minus the variable "Overdraft", and a higher value represents less frequently overdraw.

With the method of factor analysis, I create an aggregate measure of self-control by using three proxies of self-control ability. This study aims to capture the changes in people's self-control ability over time by calculating each respondent's aggregate measure of self-control in each wave. All the three proxies of self-control ability are constructed to be positively related with self-control ability.

The statistical method of factor analysis describes the variability among observed variables $\left(x_{1}, x_{2}, \ldots, x_{n}\right)$ in terms of unobserved variables. Unobserved variables are called common factors. Each observed variable $\left(x_{j}\right)$ is modelled as the linear combinations of a set of common factors $\left(F_{1}, \ldots, F_{m}\right.$, with $\left.\mathrm{m}<\mathrm{n}\right)$ and a unique factor $\left(U_{j}\right)$ for each variable: $x_{j}=a_{j 1} F_{1}+a_{j 2} F_{2}+\cdots+a_{j m} F_{m}+d_{j} U_{j}$. 
Table 4.3. Factor analysis to create an aggregate measure of self-control in 2005-2009

\begin{tabular}{lccc}
\hline \hline Behavioral measures & Factor Loadings & Uniqueness & Scoring Coefficient \\
\hline Not smoking $(=1)$ & 0.3036 & 0.9078 & 0.2748 \\
Saving habit & 0.2663 & 0.9291 & 0.2355 \\
Less overdraw & 0.1939 & 0.9624 & 0.1656 \\
\hline
\end{tabular}

Note: Factor analysis is used to create an aggregate measure of self-control from three behavioral proxies of self-control ability. Entries in the table represent maximum likelihood estimates for a factor analysis model with one factor retained.

I estimate a factor model via maximum likelihood (Harman, 1976) with three proxies of the self-control ability, which are presented in Table 4.3. The factor analysis retains only one common factor, which has positive factor loadings with all variables as expected. The common factor is assumed to measure the self-control ability, which is the only unobserved factor that is positive related with all three proxy variables (DellaVigna \& Paserman, 2006). The aggregate measure of self-control is a weighted average of the individual proxy variables. The measure that received the highest weight is the dummy variable of not smoking. Since I pool the data from 2005 to 2009 to do factor analysis, the same weights will be used to construct the aggregate measure of self-control ability in each wave. Only when different answers are provided to three proxies in different years, the aggregate measure of self-control will change in waves.

\subsubsection{Other Control Variables}

SAVE provides the demographic and socio-economic information in each wave, such as head's age, nationality (German or not), marital status (single, married, separated, divorced, widowed), family size, employment status (full-time, part-time, unemployed, retired). A fixed-effects model controls for all time-invariant variables such as gender. 
Therefore, I will control for time-variant variables that have influences on household savings. Below is a discussion of time-variant variables that may affect household savings.

Total monthly income

Household income is an important determinant of household savings. Holding other factors, households with high income have more resources to save than those with low income. In each wave, the respondents are asked their net average monthly income from all sources after paying tax and social insurance contributions in the previous year. For households who cannot give an accurate estimate of their monthly income, the respondents are asked to provide an approximate figure of their total monthly income in the previous year among 14 ranges. The data center of SAVE has made use of this information to impute the monthly income, and the imputed total monthly income will be used in following empirical analysis. Moreover, I use the year 2009 as the base year to calculate real amounts. The values of CPI from 2005 to 2008 are $0.93458,0.9495$, 0.97103 , and 0.99626 respectively in Germany. Given the skewed distribution of the total monthly income, it will be transformed by using the natural log function. For households with zero income, their log income will be coded as zero. The log income will be included in the fixed-effects model as a continuous variable.

Total windfall in the past year 
In the permanent income hypothesis, the transitory income has a different propensity to consume from the permanent income (Friedman, 1957). Therefore, the amount of windfall in the past year is expected to have a different impact on household savings. In each wave, the respondents are asked whether they get ten types of windfall over $€ 500$ among inheritance of an amount of money or capital sum, inheritance of a house or property, gift of an amount of money or capital sum, life insurance or other form of pension paid out, building society savings agreement paid out, a win on the lottery, a one-off profits-related bonus from an employer (not the contractually agreed thirteenth monthly salary), sharing of assets after a divorce, income tax repayment, and other oneoff receipts of money or capital. The respondents are also asked to provide the amount of each received windfall. The real total windfall in each wave will be transformed by using the natural $\log$ function.

Marital status

When there is a change in marital status, household finance will has some changes accordingly. Getting married can increase income sources and wealth accumulation, while divorce works in the opposite way. Households will make their savings and consumption decisions accordingly. I create five dummies to represent different marital status: single, married, separated, divorced, and widowed.

Health status 
Since health status can impact labor supply and expenditure, it will have an influence on household savings. Household head in times with better health status will have better financial situation than in times with worse health status. Therefore, I expect that health status is related with household savings over time. A discrete variable is created to represent head's health status: $=5$ if very good; $=4$ if good; $=3$ if fair; $=2$ if bad; $=1$ if very bad.

Expectations

Expectations can play an important role in household financial decisions since people will react to their own expectations and make decisions accordingly. Household with negative expectations about the economy will tend to save and prepare for future financial difficulties. In each wave, respondents are asked to indicate their expectation about German economy, expectation about own finance, and expectation about own health, according to a scale of 0 to 10.0 means very negative expectation, and 10 means very positive expectation. The original values in these three expectations will be used as control variables in the model.

\section{Residence in East Germany}

The residence of respondents is coded to be 1 if living in East Germany, and 0 if living in West Germany. Given the historical differences between East and West Germany, respondents living in East Germany may have different attitude towards professional financial advice or different financial behavior from those in West Germany 
(Fulbrook, 2011; Kuhn, 2013). For example, Ockenfels and Weimann (1999) find that eastern subjects behave in a significantly different manner from western subjects by conducting economic experiments in two parts of Germany. Therefore, I also control for the residence in East Germany in the empirical analysis, since changes in residence may correlate with changes in financial behaviors.

Saving reasons

Households save for a variety of reasons, such as the precautionary motive and the bequest motive (Browning \& Lusardi, 1996). The SAVE survey directly asks about respondents' saving motives (Schunk, 2009). Households are asked to rate the importance of nine saving motives in their own view, with a scale from 0 ("of absolutely no importance") to 10 ("of the highest importance"). Since the importance of saving reasons is critical motivations for household savings, I also make use of the detailed information about these nine types of saving reasons in SAVE: save for purchase of own home, save for provision for unexpected events, save for paying off debts, save for oldage provision, save for travels during vacation, save for major purchases (vehicle, furniture, etc.), save for education/support of children or grandchildren, save for bequests for children/grandchildren, and save for taking advantage of state subsidies. In the empirical analysis, I control for nine types of saving motives because changes in saving motives are related with saving behaviors as well as the choice of seeking professional financial advice. 
Table 4.4 provides a summary of variables and corresponding survey questions used in this study. 
Table 4.4: Variables and corresponding questions

\begin{tabular}{|c|c|c|}
\hline Variable & Question in questionnaire 2007 & Characteristics \\
\hline Total monthly income & $\begin{array}{l}\text { Question } 72 \text { : If you count everything: What is the net average } \\
\text { monthly income that you and your partner have received from } \\
\text { all these sources in } 2006 \text { after paying tax and social insurance } \\
\text { contributions? }\end{array}$ & Continuous \\
\hline Have windfall income & $\begin{array}{l}\text { Question 44: In 2006, did you or your partner receive any } \\
\text { large unusual incoming payments or inheritances of over } € \\
\text { 500? Which of the following situations applies? (State all that } \\
\text { apply.) - Inheritance of } \\
\text { an amount of money or capital sum, e.g. securities } \\
\text { - Inheritance of a house or property } \\
\text { - Gift of an amount of money or capital sum } \\
\text { - Life insurance or other form of pension paid out } \\
\text { - Building society savings agreement paid out } \\
\text { - A win on the lottery } \\
\text { - A one-off profits-related bonus from employer (not the } \\
\text { contractually agreed thirteenth monthly salary) } \\
\text { - Sharing of assets after a divorce } \\
\text { - Income tax repayment } \\
\text { - Other one-off receipts of money or capital } \\
\text { - No, nothing like this }\end{array}$ & Dummy \\
\hline $\begin{array}{l}\text { Annual windfall } \\
\text { income }\end{array}$ & $\begin{array}{l}\text { Question 45: And how large were these one-off receipts } \\
\text { (indicated in question 44): }\end{array}$ & Continuous \\
\hline Savings out of windfall & $\begin{array}{l}\text { Question 47: "Savings investment with a clearly defined } \\
\text { purpose (e.g. in the form of a building society savings } \\
\text { agreement, whole life insurance policy, private pension plan)" } \\
\text { + "Other financial investment, e.g. purchase of shares or } \\
\text { securities" + "Purchase of a flat or house" + "Repayment of } \\
\text { debts" }\end{array}$ & Continuous \\
\hline Total annual savings & $\begin{array}{l}\text { Question 56: Could you tell us how much money you and } \\
\text { your partner together have saved in the year } 2006 ? \text { - Savings } \\
\text { in the year } 2006: \overline{\text { or I have dipped into my savings. }} \\
\text { anything in } 2006 \text { or haved }\end{array}$ & Continuous \\
\hline Have pension & $\begin{array}{l}\text { Question 100: Did you or your partner hold one of the } \\
\text { following types of private or occupational pension contracts in } \\
\text { December 2006? If so, please state how many contracts you } \\
\text { owned, as well as their value at the end of last year. - Whole } \\
\text { life insurance policies; - Occupational life insurance; - Other } \\
\text { occupational pension schemes; - State-subsidized private } \\
\text { pension scheme ("Riester pension"); - Other contractally } \\
\text { agreed private pension scheme; - None of these. }\end{array}$ & Dummy \\
\hline $\begin{array}{l}\text { Own pension } \\
\text { contribution }\end{array}$ & $\begin{array}{l}\text { Question 100: (if one respondent has pension) please state... } \\
\text { the value of your monthly contributions. }\end{array}$ & Continuous \\
\hline Have loans & $\begin{array}{l}\text { Question 101: Did you or your partner have any loans at the } \\
\text { end of } 2006 \text { that had not been paid off completely - e.g. for } \\
\text { financing your own home, vehicle, holiday, etc.? - Yes; - No. }\end{array}$ & Dummy \\
\hline
\end{tabular}

Continued 
Table4.4: continue

\begin{tabular}{|c|c|c|}
\hline Annually paid loan & $\begin{array}{l}\text { Question 105: How much of these loans have you or your } \\
\text { partner paid back in the year 2006? Please do not count } \\
\text { interest payments. }\end{array}$ & Continuous \\
\hline Emergency funds & $\begin{array}{l}\text { Question 58: What savings do you and your family require to } \\
\text { provide for unforeseen circumstances? Figure saved for } \\
\text { emergency: }\end{array}$ & Continuous \\
\hline Total pension & $\begin{array}{l}\text { Question 100: (if one respondent has pension) please state... } \\
\text { their value at the end of last year. }\end{array}$ & Continuous \\
\hline Financial assets & $\begin{array}{l}\text { Question 99: Did you or your partner own one of the } \\
\text { following types of assets in December 2006? If so, please } \\
\text { state the balance of your assets at the end of the year } 2006 \text {. }\end{array}$ & Continuous \\
\hline Illiquid assets & $\begin{array}{l}\text { Question } 94 \text { (house value), } 97 \text { (other real estate), } 100 \text { (pension } \\
\text { value), } 107 \text { (business value), and } 109 \text { (value of other assets, } \\
\text { e.g. jewelry and antiquities). Get the sum of those values. }\end{array}$ & Continuous \\
\hline Total assets & Liquid financial assets + illiquid assets & Continuous \\
\hline Total loans & $\begin{array}{l}\text { Question 103: How much was owed on the individual loans at } \\
\text { the end of the last year? Five categories: building society } \\
\text { loan, mortgage, consumer credit loan, family loan, and other } \\
\text { loans. }\end{array}$ & Continuous \\
\hline Net worth & Total assets - Total loans & Continuous \\
\hline \multicolumn{3}{|l|}{ Independent variables } \\
\hline \multicolumn{3}{|l|}{ Advice-seeking behaviors } \\
\hline $\begin{array}{l}\text { Professional financial } \\
\text { advice (PFA) }\end{array}$ & $\begin{array}{l}\text { Question 41: Do you discuss financial matters with financial } \\
\text { advisors in banks, insurance companies or financial service } \\
\text { providers. } \\
\text { Note: }=1 \text { if Yes; }=0 \text { if No. }\end{array}$ & Dummy \\
\hline PFA seeking frequency & $\begin{array}{l}\text { Question 42: How often do you ask for advice? (Note: this } \\
\text { question is answered only by households who got } \\
\text { professional financial advice. Same with Question } 43 \text { ) } \\
\text { Note: }=12 \text { if at least once a month; }=4 \text { if about four times a } \\
\text { year; }=1 \text { if once a year; }=0.5 \text { if less than once a year }\end{array}$ & Discrete \\
\hline $\begin{array}{l}\text { Self-reported PFA } \\
\text { following }\end{array}$ & $\begin{array}{l}\text { Question 43: How closely do you follow the advice given to } \\
\text { you? ( } 0 \text { means: I don't take any notice of advice given to me } \\
\text { by financial advisors/customer advisors. } 10 \text { means: I take the } \\
\text { advice given to me by financial/customer advisors very } \\
\text { seriously.) }\end{array}$ & $\begin{array}{l}\text { Discrete } \\
\text { with a scale } \\
\text { from } 0 \text { to } 10\end{array}$ \\
\hline $\begin{array}{l}\text { Non-professional financial } \\
\text { advice }\end{array}$ & $\begin{array}{l}\text { Question 41: Do you discuss financial matters with relatives } \\
\text { who do not live in the same house, friends, work colleges, or } \\
\text { neighbors. } \\
\text { Note: }=1 \text { if Yes; }=0 \text { if No. }\end{array}$ & Dummy \\
\hline
\end{tabular}

Continued 
Table4.4: continue

\begin{tabular}{|c|c|c|}
\hline $\begin{array}{l}\text { Self-Control } \\
\text { Measures }\end{array}$ & & \\
\hline Saving habit & $\begin{array}{l}\text { Question } 52 \text { : Which sentence best describes the personal savings } \\
\text { behavior of you and your partner?- I/we save a fixed amount regularly, } \\
\text { for instance in a savings account, a savings plan, in shares or in a life } \\
\text { insurance scheme. -I/we put something aside each month but I/we } \\
\text { decide on the amount according to the financial circumstances. -I/we } \\
\text { put something aside when we have something left over to save. - I/we } \\
\text { do not save because we do not have enough scope financially to do so. - } \\
\text { I/we do not save because we would prefer to enjoy life now. } \\
\text { Note: }=5 \text { if saving a fixed amount regularly; }=4 \text { if put something aside } \\
\text { each month; =3 if save whatever is left over; = } 2 \text { if do not save due to } \\
\text { scarcity; }=1 \text { if do not save as decided. }\end{array}$ & Discrete \\
\hline Not smoking & $\begin{array}{l}\text { Question 29: Do you or your partner smoke regularly? } \\
\text { Note: }=1 \text { if No; }=0 \text { if Yes. }\end{array}$ & Dummy \\
\hline Less overdraw & $\begin{array}{l}\text { Question 61: "Does your account have an overdraft facility?" } \\
\text { (Answers: Yes; No.) \& Question 62: "How often do you go overdrawn } \\
\text { on your current account?" (Answer: Never; Seldom; Often.) \& } \\
\text { Question 64: "How often do you make use of your overdraft facility?" } \\
\text { (Answer: Never; 1-3 times per year; 4-6 times per year; more } \\
\text { frequently or use it continually). } \\
\text { Note: =2 if accounts don't have overdraft facility (Q61) or never } \\
\text { overdraw (Q62, Q64); =1 if seldom overdraw on the current account } \\
\text { (Q62), or 1-3 times per year (Q64); =0 otherwise. }\end{array}$ & Dummy \\
\hline $\begin{array}{l}\text { Self-assessed } \\
\text { patience }\end{array}$ & $\begin{array}{l}\text { Question } 125 \text { : To what extent do the following statements apply to } \\
\text { you? Please answer on a scale of } 0 \text { to } 10 \text {, where } 0 \text { means "does not } \\
\text { apply at all" and } 10 \text { means "applies very well". - I simply care about } \\
\text { immediate matters, as future problems often sort themselves out. - } \\
\text { Activities that exhibit tangible and immediate results are more } \\
\text { important to me than activities whose results do not materialize until } \\
\text { the remote future. Question } 126 \text { : Where would you place yourself in } \\
\text { terms of the two following personality types? Please answer on a scale } \\
\text { from } 0 \text { to } 10 \text {. Note that } 0 \text { means: I am easy going and take each day as } \\
\text { it comes. I don't think or worry much about the future. } 10 \text { means: I } \\
\text { think about the future a lot and have a pretty good idea of where I want } \\
\text { to be and want to do in the future. Question 127: Where would you } \\
\text { place yourself in terms of the two following personality types? Please } \\
\text { answer on a scale from } 0 \text { to } 10 \text {. Note that } 0 \text { means: I am quick and } \\
\text { impulsive when it comes to taking decisions. I want to have the things } \\
\text { that I like straightaway. } 10 \text { means: I wait and weigh things up and need } \\
\text { a good deal of time in order to reach a decision or form an opinion. } \\
\text { Note } 1 \text { : Use the result of "10 minus original value" in Q125, and use } \\
\text { the original value in Q126 and Q127. Then, use the average value of all } \\
\text { answers to questions available in the corresponding year as the variable } \\
\text { "self-assessed patience." } \\
\text { Note 2: Q125 is available in } 2007 \text { and } 2008 \text {; Q126 and Q127 are } \\
\text { available in } 2005,2006 \text { and } 2007 \text {. }\end{array}$ & Discrete \\
\hline
\end{tabular}

Continued 
Table4.4: continue

\begin{tabular}{|c|c|c|}
\hline Budgeting & $\begin{array}{l}\text { Question 59: Do you or your partner routinely keep a record of your } \\
\text { household's income and expenditure? - Yes; - No. } \\
\text { Note: available from } 2005 \text { to } 2008 \text {. }\end{array}$ & Dummy \\
\hline \multicolumn{3}{|l|}{ Control Variables } \\
\hline Age of head & $\begin{array}{l}\text { Question 3: In which year were you born? } \\
\text { (Note: Calculate age from this information) }\end{array}$ & Discrete \\
\hline Gender of head & $\begin{array}{l}\text { Question 2: Are you Male or Female? } \\
\text { Note: }=1 \text { if Male; }=0 \text { if Female. }\end{array}$ & Dummy \\
\hline $\begin{array}{l}\text { German } \\
\text { nationality }\end{array}$ & $\begin{array}{l}\text { Question 4: Are you German? (If you have dual nationality, please } \\
\text { answer "Yes".) }\end{array}$ & Dummy \\
\hline Education & Question 15 (high school) and Question 16 (university) & $\begin{array}{l}2 \text { dummy } \\
\text { variables }\end{array}$ \\
\hline Marital status & $\begin{array}{l}\text { Question 5: What is your marital status? } \\
\text { - Married, living with husband/wife; } \\
\text {-Separated; } \\
\text { - Single; } \\
\text { - Divorced; } \\
\text { - Widowed. }\end{array}$ & $\begin{array}{l}5 \text { dummy } \\
\text { variables }\end{array}$ \\
\hline Live with a partner & $\begin{array}{l}\text { Question 6: Do you live with a partner on a permanent basis? - Yes; } \\
\text { - No }\end{array}$ & Dummy \\
\hline Family size & $\begin{array}{l}\text { Question 14: Counting everyone, how many people live in your } \\
\text { home? Number of persons in the household, including you yourself, } \\
\text { your partner, children and other persons. }\end{array}$ & Discrete \\
\hline $\begin{array}{l}\text { Full-time } \\
\text { employed }\end{array}$ & $\begin{array}{l}\text { Question 17: Full-time employment working } 35 \text { hours or more a } \\
\text { week }\end{array}$ & Dummy \\
\hline $\begin{array}{l}\text { Part-time } \\
\text { employed }\end{array}$ & $\begin{array}{l}\text { Question 17: "Part-time employment working at least } 15 \text { hours but } \\
\text { less than } 35 \text { hours per week" or "Low level of employment, working } \\
\text { less than } 15 \text { hours per week" or "Casual work". }\end{array}$ & Dummy \\
\hline Retired & $\begin{array}{l}\text { Question } 83 \text { "I have already retired or have retired early" or } \\
\text { Question } 84 \text { "My partner and I are already retired and are already } \\
\text { receiving retirement income." }\end{array}$ & Dummy \\
\hline Head health status & $\begin{array}{l}\text { Question } 26 \text { : Would you say your health is? } \\
\text { Note: }=5 \text { if very good; }=4 \text { if good; }=3 \text { if fair; }=2 \text { if bad; }=1 \text { if very } \\
\text { bad }\end{array}$ & Discrete: \\
\hline Life expectancy & $\begin{array}{l}\text { Question 115: What average age do you believe men/women of your } \\
\text { age will reach? } \\
\text { (Note: If head is male, use the male life expectancy; If head is } \\
\text { female, use the female life expectancy.) }\end{array}$ & Continuous \\
\hline
\end{tabular}

Continued 
Table4.4: continue

\begin{tabular}{|c|c|c|}
\hline Expectations & $\begin{array}{l}\text { Question 110: We would now like to know a little about your views on } \\
\text { future developments. Please indicate, according to a scale of } 1 \text { to } 10.0 \\
\text { means very negative } 10 \text { means very positive. } \\
\text { - The economic development of Germany } \\
\text { - Your own financial situation } \\
\text { - Your own health situation }\end{array}$ & $\begin{array}{l}3 \text { discrete } \\
\text { variables }\end{array}$ \\
\hline Saving reasons & $\begin{array}{l}\text { Question 57: Below a few reasons for saving are listed. How important } \\
\text { are these reasons in your view? Please rate these on a scale of } 0 \text { to } 10 \text {; } \\
\text { where } 0 \text { means totally unimportant and } 10 \text { means very important. } \\
\text { - Purchase of own home } \\
\text { - Provision for unexpected events } \\
\text { - Paying off debts } \\
\text { - Old-age provision } \\
\text { - Travels during vacation } \\
\text { - Major purchases (vehicle, furniture, etc.) } \\
\text { - Education/support of children or grandchildren } \\
\text { - Bequests for children/grandchildren } \\
\text { - Taking advantage of state subsidies (for example, a subsidy to } \\
\text { building society savings) }\end{array}$ & $\begin{array}{l}9 \text { discrete } \\
\text { variables }\end{array}$ \\
\hline
\end{tabular}




\subsection{Empirical model}

\subsubsection{Fixed-effects model}

Both unobserved and observed heterogeneity may affect the effects of professional financial advice on saving behaviors. I will use a fixed-effects model to test the hypotheses. Two specification equations will be used in this study:

$Y_{i t}=\alpha+\beta_{1} * P F A_{i t}+\beta_{2} *$ SelfCon $_{i t}+\gamma X_{i t}+\mu_{i}+v_{t}+\varepsilon_{i t}$

$Y_{i t}=\alpha+\beta_{1} *$ PFA $_{i t}+\beta_{2} *$ SelfCon $_{i t}+\beta_{3} * P F A_{i t} *$ SelfCon $_{i t}+\gamma X_{i t}+\mu_{i}+v_{t}+\varepsilon_{i t}$

The individual-specific variable $\mu_{i}$ and time-specific variable $v_{t}$ are assumed to be fixed parameters to be estimated, and the error term $\varepsilon_{i t}$ is assumed to be independent and identically distributed $N\left(0, \sigma_{\varepsilon}^{2}\right)$. Therefore, the individual- and time-specific intercept is equal to $\left(\alpha+\mu_{i}+v_{t}\right)$ for each observation. The 2008-2009 financial recession has dramatic effects on the world economy, including Germany (Van Roye, 2011). Therefore, the year dummies are included in the specifications to capture the time-specific effects. The dummy variable $P F A_{i t}$ equals to 1 if respondent $i$ reports to get professional financial advice in year $t, 0$ otherwise. The variable SelfCon $i t$ is the created aggregate measure of self-control ability. The symbol $X_{i t}$ represents other control variables, such as marital status, employment status and income. The interaction term in the second empirical model intends to test whether the effect of professional financial advice on savings varies among people with different levels of self-control. According to three hypotheses, the coefficients of interests are expected to be: $\beta_{1}>0, \beta_{2}>0$, and $\beta_{3}<0$.

The advantage of a fixed-effect model is to control for all time-invariant characteristics of individuals in the study, which can eliminate potentially large sources 
of bias. A fixed-effects model is likely to get unbiased estimates by restricting to the within-individual variation, since the between-individual variation is likely to be contaminated by unmeasured individual characteristics.

\subsubsection{Model selection}

The first alternative model is the pooled OLS, which assume that all respondents have the same intercept instead of individual-specific intercepts. The null hypothesis is that $\mu_{i}=0$, and $v_{t}=0$, for $i=1, \ldots, n-1$, and $t=1,2,3,4$. The F-test rejects the null hypothesis which assumes no fixed-effects. This means that at least one individualspecific or time-specific intercept is significantly not zero. Therefore, the fixed-effects model is better than the pooled OLS.

A random-effects model is another alternative model for the panel data. The random-effects model assumes that the individual-specific heterogeneity is a component of the error term. The error term in a random-effects model is $\mu_{i}+v_{t}+\varepsilon_{i t}$, where $\mu_{i} \sim$ i.i.d. $\left(0, \sigma_{\mu}^{2}\right), v_{t} \sim i . i . d .\left(0, \sigma_{v}^{2}\right), \varepsilon_{i t} \sim i . i . d .\left(0, \sigma_{\varepsilon}^{2}\right)$. The $\mu_{i}$ and $v_{t}$ are assumed independent of $\varepsilon_{i t}$ and independent variables. In a random-effects model, all individuals have the same intercept but have individual-specific errors. A random-effects model has the potential problem to produce inconsistent estimates if individual-specific effects are actually correlated with some independent variables. The random effects are tested by the Lagrange multiplier (LM) test (Breusch and Pagan, 1980). The null hypothesis is that

$\sigma_{\mu}^{2}=0$ and $\sigma_{v}^{2}=0$. Since the LM test rejects the null hypothesis that there is no random effects, the conclusion is that a random-effects model is better than the pooled OLS model. 
Since both fixed-effects model and random-effects model are better than the pooled OLS model, the Hausman test will be used to compare a fixed-effects model to its random-effect counterpart (Hausman, 1978). The Hausman test examines how significantly estimates differ between a fixed-effects model and a random-effects model (Greene, 2003). The null hypothesis is that the individual effects are uncorrelated with independent variables. If individual effects are related with independent variables in the model, a random-effects model violates one of the Gauss-Markov assumptions and produces biased estimations. In this study, the Hausman test rejects the null hypothesis, and a fixed-effects model is more appropriate than its random-effects counterpart. 


\section{Chapter 5. Results}

This chapter will present descriptive statistics and empirical results. Section 5.1 will present the summary statistics of the dependent and also explanatory variables including financial behavior variables, demographic variables, and saving reasons. Section 5.2 will discuss findings from two specifications of the fixed-effects model. The empirical analysis will be organized as savings out of windfall, total annual savings, own monthly pension contribution, emergency funds, financial assets, illiquid assets, total assets and total loan. For robustness check, the section 5.3 will present empirical results by using the 2005-2008 sample and empirical results by using five proxies of self-control ability in factor analysis.

\subsection{Descriptive Statistics}

Table 5.1 presents summary statistics of income and assets variables from 2005 to 2009 in SAVE. The summary statistics and estimations are not weighted in this study. The sample refreshment and attrition in the panel are important reasons behind the fluctuations of mean values. However, some patterns emerge from the summary statistics 
which will be described below. All the savings, income and assets (in Euro) have been transformed into real amounts by using 2009 as the base year.

The average monthly income after paying tax and social insurance contributions is around $€ 2,400$ for households in the sample from 2005 to 2009 . Using F-test to compare group means among five years, the difference of the average monthly income is significant at the 0.01 level. About $30 \%$ households get windfall income in each year. Among households who get a windfall, the average annual amount of windfall fluctuates during this period, with the lowest amount $€ 12,693$ in 2005 and the highest amount $€ 20,296$ in 2007 . The average savings out of annual windfall income reaches the lowest amount $€ 5,711$ in 2005 and the highest amount $€ 9,835$ in 2006 . However, there is no significant difference in group means for the average annual windfall income and the annual savings out of windfall. The average annual total savings reaches the highest amount $€ 3,585$ in 2006 and the lowest amount $€ 2,394$ in 2009 . There are $28.7 \%$ households who have pension contracts in 2005, and this proportion has increased to about $40 \%$ in 2006 . Among households with pension contracts, the median monthly contribution by households themselves is less than $€ 70$ in all years.

The average emergency-funds savings is the highest in 2006, and the lowest in 2008. Given the 2008 recession, the average total illiquid assets are low in 2008 and 2009, with significant differences across those five years. However, there is no significant difference in means of total financial assets and t total loan from 2005 to 2009. The differences in mean of total assets and net worth are significant. 
Table 5.1. Descriptive statistics of income and savings (in Euro)

\begin{tabular}{|c|c|c|c|c|c|c|}
\hline $\begin{array}{r}\text { Sample: } \\
\text { Sample size: }\end{array}$ & $\begin{array}{l}2005 \\
2,305\end{array}$ & $\begin{array}{l}2006 \\
3,474 \\
\end{array}$ & $\begin{array}{l}2007 \\
2,931 \\
\end{array}$ & $\begin{array}{l}2008 \\
2,608 \\
\end{array}$ & $\begin{array}{l}2009 \\
2,222 \\
\end{array}$ & $\Delta$ \\
\hline Total monthly income & 2,576 & 2,380 & 2,387 & 2,258 & 2,358 & $* * *$ \\
\hline Have windfall income $(=1)$ & 0.213 & 0.354 & 0.338 & 0.326 & 0.276 & $* * *$ \\
\hline Annual windfall income $\mid$ Have & 12,693 & 15,966 & 20,296 & 13,640 & 13,288 & \\
\hline Savings out of windfall | Have & 5,711 & 9,835 & 8,642 & 8,661 & 8,841 & \\
\hline Total annual savings & 2,510 & 3,585 & 3,017 & 3,000 & 2,394 & $* *$ \\
\hline Have pensions $(=1)$ & 0.287 & 0.414 & 0.398 & 0.396 & 0.401 & $* * *$ \\
\hline Own pension contributiona| Have & 27 & 68 & 34 & 40 & 50 & $* * *$ \\
\hline Have Loans $(=1)$ & 0.400 & 0.443 & 0.430 & 0.434 & 0.419 & $* *$ \\
\hline Annual paid loan | Have Loans & 3,940 & 3,800 & 3,872 & 3,866 & 3,984 & \\
\hline Emergency funds & 10,465 & 13,001 & 12,993 & 8,920 & 10,151 & $* *$ \\
\hline Total financial assets & 34,574 & 35,240 & 36,189 & 36,709 & 37,977 & \\
\hline Total illiquid assets & 206,471 & 179,384 & 196,517 & 165,684 & 164,868 & $* * *$ \\
\hline Total assets & 241,046 & 214,624 & 232,706 & 202,393 & 202,845 & $* *$ \\
\hline Total loan & 76,893 & 70,374 & 72,375 & 67,758 & 65,321 & \\
\hline Net worth & 210,255 & 183,468 & 201,618 & 172,957 & 175,447 & $*$ \\
\hline
\end{tabular}

Notes: New households were added in 2006 . Use 2009 as the base year to get real amounts. The values of CPI from 2005 to 2008 are $0.93458,0.9495,0.97103$ and 0.99626 respectively in Germany. $\stackrel{a}{-}$ represents median value. $* * *$ difference in means significant at $1 \%, * *$ difference in means significant at $5 \%$, and $*$ difference in means significant at $10 \%$. 
Table 5.2: Descriptive statistics of advice-seeking behaviors and self-control measures

\begin{tabular}{|c|c|c|c|c|c|c|}
\hline $\begin{array}{l}\text { Sample: } \\
\text { Sample size: }\end{array}$ & $\begin{array}{l}2005 \\
2,305 \\
\end{array}$ & $\begin{array}{l}2006 \\
3,474 \\
\end{array}$ & $\begin{array}{l}2007 \\
2,931 \\
\end{array}$ & $\begin{array}{l}2008 \\
2,608 \\
\end{array}$ & $\begin{array}{l}2009 \\
2,222 \\
\end{array}$ & $\Delta$ \\
\hline \multicolumn{7}{|l|}{ Advice-Seeking Behaviors } \\
\hline Professional financial advice $(\mathrm{PFA}=1)$ & 0.278 & 0.379 & 0.333 & 0.352 & 0.351 & $* * *$ \\
\hline PFA frequency $\mid \mathrm{PFA}=1$ & 1.60 & 1.79 & 1.63 & 1.57 & 1.69 & $*$ \\
\hline Follow PFA $\mid \mathrm{PFA}=1$ & 5.88 & 5.91 & 6.04 & 6.20 & 6.12 & $* * *$ \\
\hline Non-professional financial advice $(=1)$ & 0.426 & 0.495 & 0.428 & 0.444 & 0.422 & $* * *$ \\
\hline \multicolumn{7}{|l|}{ Self-Control Measures } \\
\hline Self-control (aggregate measure) & -0.049 & -0.030 & -0.003 & 0.037 & 0.059 & $* * *$ \\
\hline Saving habit & 3.66 & 3.76 & 3.76 & 3.72 & 3.69 & $* *$ \\
\hline Not smoking $(=1)$ & 0.697 & 0.715 & 0.733 & 0.743 & 0.756 & $* * *$ \\
\hline Less overdraw & 1.35 & 1.23 & 1.24 & 1.33 & 1.37 & $* * *$ \\
\hline
\end{tabular}

In the 2005-2009 sample, about one third households get professional financial advice (PFA), and more than 40\% households get non-professional financial advice from relatives, friends, coworkers or neighbors each year. In the 2006 sample, the proportion of getting professional financial advice is $37.9 \%$ the highest among those five years. There are about half of households who report to get non-professional financial advice in 2006.

Among households who get PFA, the average frequency to get PFA is about 1 to 2 times per year, and the self-reported extent to follow the received PFA is around 6 points out of a 10-point scale in all waves. In each year, about half of them report the frequency of once a year in seeking PFA, and only a small portion report the frequency of 
at least once a month. There are significant differences in the percentage to get PFA, the extent to follow PFA, and the percentage to get non-professional financial advice across years at the 0.01 level. The differences in following the received PFA are only significant at the 0.1 level.

About self-control measures, the average self-reported saving habit is between 3 (which means "I/We put something aside when I have something left over to save") and 4 (which means "I/We do not save because I do not have enough scope financially to do so") in all waves. The percentage of non-smoker has increases over the years in both the whole sample and the balanced sample. The aggregate measure of self-control is created to have zero mean and one standard deviation in the whole sample, and a higher aggregate measure represents higher levels of self-control ability. In the whole sample, the mean of the aggregate self-control measure has increased from -0.049 in 2005 to 0.059 in 2009. This is consistent with the age-related increase in self-control in psychological studies (Green et al., 1994, Green et al., 1999). There are significant differences in the average aggregate measures of self-control, not smoking, and less overdraw at the 0.01 level. The differences in the average saving habits are significant at the 0.05 level. 
Table 5.3: Descriptive statistics of socioeconomic characteristics (Head)

\begin{tabular}{|c|c|c|c|c|c|c|}
\hline $\begin{array}{r}\text { Sample: } \\
\text { Sample size: }\end{array}$ & $\begin{array}{l}2005 \\
2,305\end{array}$ & $\begin{array}{l}2006 \\
3,474\end{array}$ & $\begin{array}{l}2007 \\
2,931\end{array}$ & $\begin{array}{l}2008 \\
2,608\end{array}$ & $\begin{array}{l}2009 \\
2,222\end{array}$ & $\Delta$ \\
\hline Age & 51.17 & 50.90 & 52.58 & 53.98 & 55.44 & $* * *$ \\
\hline Life expectancy & 76.76 & 76.79 & 77.50 & 77.44 & 77.62 & $* * *$ \\
\hline Male $(=1)$ & 0.498 & 0.493 & 0.483 & 0.478 & 0.480 & \\
\hline German nationality $(=1)$ & 0.967 & 0.969 & 0.985 & 0.987 & 0.989 & $* * *$ \\
\hline East Germany $(=1)$ & 0.296 & 0.260 & 0.276 & 0.279 & 0.278 & ** \\
\hline High School (=1) & 0.234 & 0.289 & 0.286 & 0.281 & 0.281 & $* * *$ \\
\hline University $(=1)$ & 0.136 & 0.171 & 0.176 & 0.171 & 0.172 & $* * *$ \\
\hline Family Size & 2.48 & 2.44 & 2.40 & 2.40 & 2.34 & $* * *$ \\
\hline Live with a partner $(=1)$ & 0.659 & 0.675 & 0.668 & 0.679 & 0.679 & \\
\hline Married (=1) & 0.595 & 0.586 & 0.588 & 0.602 & 0.604 & \\
\hline Separated $(=1)$ & 0.025 & 0.027 & 0.030 & 0.025 & 0.027 & \\
\hline Single $(=1)$ & 0.178 & 0.201 & 0.183 & 0.166 & 0.157 & $* * *$ \\
\hline Divorced (=1) & 0.109 & 0.111 & 0.114 & 0.118 & 0.116 & \\
\hline Widowed (=1) & 0.093 & 0.076 & 0.085 & 0.089 & 0.095 & $*$ \\
\hline Full-time employed $(=1)$ & 0.319 & 0.328 & 0.329 & 0.321 & 0.314 & \\
\hline Part-time employed $(=1)$ & 0.167 & 0.168 & 0.163 & 0.153 & 0.144 & * \\
\hline Unemployed (=1) & 0.184 & 0.154 & 0.149 & 0.140 & 0.128 & *** \\
\hline Retired (=1) & 0.330 & 0.350 & 0.360 & 0.386 & 0.414 & *** \\
\hline Home owner (=1) & 0.504 & 0.502 & 0.511 & 0.519 & 0.541 & * \\
\hline Expectation of German economy & 3.32 & 3.64 & 4.92 & 4.49 & 3.80 & *** \\
\hline Expectation of own finance & 5.07 & 4.83 & 5.09 & 4.87 & 4.91 & $* * *$ \\
\hline Expectation of own health & 6.23 & 5.84 & 5.73 & 5.57 & 5.61 & $* * *$ \\
\hline Health status & 2.39 & 2.45 & 2.50 & 2.54 & 2.57 & $* * *$ \\
\hline
\end{tabular}

Notes: New households were added in 2006. $* * *$ difference in means significant at $1 \%$, $* *$ difference in means significant at $5 \%$, and * difference in means significant at $10 \%$. 
In the panel, because of the newly-added households in 2006, the average head age decreases from 51.17 year-old in 2005 to 50.90 year-old in 2006 . The age range is 18 years old to 95 years old in the 2005 sample, and 22 years old to 97 years old in the 2009 sample. The life expectancy of a household head is around 77 years old.

About half of the respondents are male in all waves, and more than $65 \%$ are living with a partner on a permanent basis. Less than $30 \%$ respondents live in the East Germany. More than $96 \%$ respondents have the German nationality (including dual nationality). About $25 \%$ of household heads have graduated from high school, and less than $20 \%$ household heads have a degree from universities. The respondents less than 22 years old are very likely to have higher levels of education in later years. The average family size is around 2.4 in each wave. Using F-test to compare group means among five years, there are significant differences in the average family size at the 0.01 level.

There are about one third full-time employed respondents, about 16\% part-time employed, about $15 \%$ unemployed, and more than one third retired. More than half of households are home-owners in all waves. Respondents have relatively negative average opinion about the economic development of Germany in 2005 and 2006, and their opinion becomes significantly more positive in 2007 . Comparing to the economic development of Germany, respondents have more positive attitude toward their own financial situation in each year. Both health status and the expectation of health situation decrease over time. There are significant differences in those three types of expectations. 
Table 5.4: Descriptive statistics of saving reasons

\begin{tabular}{lcccccc}
\hline \hline \multicolumn{1}{r}{ Sample size: } & 2005 & 2006 & 2007 & 2008 & 2009 & \\
& 2,305 & 3,474 & 2,931 & 2,608 & 2,222 & $\Delta$ \\
\hline Save for house purchase & 4.14 & 4.67 & 4.61 & 4.58 & 4.61 & $* * *$ \\
Save for emergency & 4.64 & 5.12 & 5.14 & 5.02 & 4.92 & $* * *$ \\
Save for paying off debts & 4.74 & 5.33 & 5.22 & 5.03 & 5.10 & $* * *$ \\
Save for old-age provision & 2.97 & 3.03 & 2.92 & 2.89 & 3.02 & \\
Save for vacation & 3.77 & 4.52 & 4.36 & 4.41 & 4.09 & $* * *$ \\
Save for major purchases & 3.89 & 4.42 & 4.35 & 4.28 & 4.26 & $* * *$ \\
Save for children education & 7.20 & 7.58 & 7.43 & 7.30 & 7.35 & $* * *$ \\
Save for bequests & 4.77 & 5.86 & 5.66 & 5.53 & 5.64 & $* * *$ \\
Save for subsidy incentives & 7.08 & 7.59 & 7.35 & 7.31 & 7.21 & $* * *$ \\
\hline Notes: New households were added in $2006 . * * *$ difference in means significant at 1\%, \\
** difference in means significant at 5\%, and * difference in means significant at 10\%.
\end{tabular}

About saving motives, to save for education/support of children or grandchildren is rated as the most important reason on average, and the second most important saving reason is for taking advantage of state subsidies. The least important saving reason is for old-age provision, which can be explained by the social welfare in Germany. The precautionary saving and bequest motive have middle importance on average. Using Ftest to compare group means among five years, there are significant differences in the average saving reasons at the 0.01 level for all types of saving motives except saving for old-age provision. 


\subsection{Results}

I use the fixed-effects model to test three hypotheses derived from the theoretical framework. Specifically, two specification equations are as below.

$Y_{i t}=\alpha+\beta_{1} * P F A_{i t}+\beta_{2} * \operatorname{SelfCon}_{i t}+\gamma X_{i t}+\mu_{i}+v_{t}+\varepsilon_{i t}$

$Y_{i t}=\alpha+\beta_{1} * P F A_{i t}+\beta_{2} * \operatorname{SelfCon}_{i t}+\beta_{3} * P F A_{i t} * \operatorname{SelfCon}_{i t}+\gamma X_{i t}+\mu_{i}+v_{t}+\varepsilon_{i t}$

Besides the common component $\alpha$, the intercept of each household in each wave has an individual-specific component $\mu_{i}$ and a time-specific component $v_{t}$. Assume that the error term $\varepsilon_{i t}$ is independent and identically distributed $N\left(0, \sigma_{\varepsilon}^{2}\right)$. The dummy variable of interest is $P F A_{i t}$, which equals to 1 if household $i$ reports to get professional financial advice in year $t, 0$ otherwise. The variable $\operatorname{SelfCon}_{i t}$ is the created aggregate measure of self-control ability. Three hypotheses predict that: $\beta_{1}>0, \beta_{2}>0$, and $\beta_{3}<$ 0.

All five implicates will be used to get the multiple-imputation (MI) estimates. The procedure is like this. The first step is to analyze each of the five imputed datasets in a fixed-effects model. The second step is to combine the results and to make inferences from five estimates. For example, for each of the five imputed datasets, an estimate of the parameter $\beta_{1}$ is obtained from a fixed-effects model, denoted by $\hat{\beta}_{1 i}$. The MI point estimate of $\beta_{1}$ is the average of the five estimates:

$$
\bar{\beta}_{1}=\frac{1}{5} \sum_{i=1}^{5} \hat{\beta}_{1 i}
$$


The variance of the MI estimate $\bar{\beta}_{1}$ has two components, which are the within imputation sampling variance and the between imputations variance. The within imputation sampling variance is the average of five variance estimates $\left(\widehat{V}_{i}\right)$, denoted as $W$ :

$$
W=\frac{1}{5} \sum_{i=1}^{5} \widehat{V}_{i}
$$

The between imputation variance is the variance of point estimates, denoted as B:

$$
B=\frac{1}{4} \sum_{i=1}^{5}\left(\hat{\beta}_{1 i}-\bar{\beta}_{1}\right)^{2}
$$

The total variance of $\bar{\beta}_{1}$ is a linear combination of $\mathrm{W}$ and $\mathrm{B}$.

$$
\operatorname{Var}\left(\bar{\beta}_{1}\right)=W+\frac{6}{5} B
$$

I use mi commands in Stata to get multiple-imputation estimations in a fixedeffects model.

\subsubsection{Short-run saving behaviors}

Households are expected to make some adjustments in their short-run financial behaviors after getting professional financial advice. This study examines four types of short-run financial behaviors to capture the impact of professional financial advice on household savings behavior. Results from two specifications are presented in Table 5.5 and Table 5.6. I only report four types of saving reasons which have more significant relationships with saving behaviors. 
Annual investment savings out of windfall

In the economics literature, the marginal propensity to consume is higher for windfall income than expected gains. Thaler (1990) suggests that people will spend a substantial proportion of windfall income, because windfall income will be put into a mental account with high marginal propensity to consume. In the psychological literature, Arkes et al. (1994) conduct five experiments to test the hypothesis that windfall income are more likely to be spent than other assets, due to its unanticipated nature. The experiment results support their hypothesis.

In two specifications, professional financial advice has a significant positive relationship with annual investment savings out of windfall. When one household changes from no-PFA to getting PFA, their annual investment savings out of windfall will increase by $14.3 \%$ after getting PFA, at the 0.05 significance level $^{3}$. A possible reason is that professional financial advisors may change how people perceive their windfall income. If professional financial advisors can convince clients to consider windfall income within their long-run financial plans, people may tend to save a larger proportion of their windfall income. However, self-control ability has no relationship with mental accounting. Therefore, there is no significant positive relationship between self-control ability and annual savings out of windfall income. In the second specification, the interaction term of PFA and self-control has an insignificant negative relationship with annual investment savings out of windfall. The significant coefficient of PFA supports the first hypothesis derived from the theoretical model.

\footnotetext{
${ }^{3}$ We have that $e^{0.134}-1=1.143-1=0.143$.
} 
Moreover, non-professional financial advice and total monthly income have no significant effects on annual investment savings out of windfall. The total annual windfall has a significant positive effect on annual investment savings out of windfall, at the 0.01 significance level. Holding other variables constant, a 10\% increase in the total annual windfall will lead to $4.75 \%$ increase in the annual investment savings out of windfall.

The demographic characteristics such as age, gender, marital status and employment status have no significant effects on annual investment savings out of windfall income. Furthermore, there is no significant relationship between saving reasons and annual investment savings out of windfall income.

Total annual savings

In two specifications, both professional financial advice and self-control have a significant positive relationship with the logarithm amount of total annual savings, at the 0.01 significance level. When one household changes from no-PFA to get PFA, their total annual savings will increase $24.6 \%$ after getting PFA. Controlling other conditions, 0.1 unit increase in the aggregate self-control measure increases the total annual savings by $16.9 \%$ at the 0.01 significance level. These findings support the first and second hypotheses. However, the interaction term of PFA and self-control ability has no significant effect on the total annual savings in the second specification.

Both total monthly income and total annual windfall have significant effects on the total annual savings. When the household monthly income increases by $1 \%$, their total annual savings will increase by about $0.28 \%$. A $1 \%$ increase in the annual total 
windfall income will lead to a $0.04 \%$ increase in the total annual savings. Since windfall income has a higher marginal propensity to consume (MPC) than regular income, household monthly income has a larger effect on total annual savings than windfall income. Respondents' expectation about own finance situation has a significant positive relationship with the total annual savings. One unit increase in the expectation of own finance situation is related with a $9.3 \%$ increase in the total annual savings. One possible explanation behind this phenomenon is the household head's rational expectation or selffulfilling prophecy.

Moreover, getting married can increase household annual total savings by $129 \%$. Comparing to full-time employment, part-time employment will decrease household annual total savings by $48 \%$, and unemployment will decrease it by $36 \%$. Since part-time employment also requires some inputs and may disqualify some welfare program participation, it has a bigger reverse effect on household total annual savings than unemployment. One unit increase in the importance of saving for emergencies will lead to $3 \%$ increase in the annual total savings. One unit increase in the importance of saving for children's education will result in 7\% increase in annual total savings. However, one unit increase in savings for bequests will reduce the annual total savings by $6.4 \%$.

Own monthly pension contribution

The literature of retirement preparation finds that households with financial plans can achieve better financial outcomes than non-planners (Lusardi \& Mitchell, 2007). With the help from professional financial advisors, households are more likely to make 
retirement planning and preparation in their working time (Marsden et al., 2011). One important retirement preparation is to contribute to pension schemes. Therefore, I also examine the relationship between professional financial advice and own monthly pension contribution. Results show that getting professional financial advice can increase own monthly pension contribution by about $11.5 \%$, at the 0.05 significance level. However, there is no significant positive relationship between self-control ability and own monthly pension contribution. In the second specification, the interaction term of PFA and selfcontrol has no significant effect on own pension contribution. The finding supports the first hypothesis about the positive relationship between PFA and savings.

There is significant positive relationship between total monthly income and own monthly pension contribution. The $10 \%$ increase in total monthly income will result in $0.78 \%$ increase in own monthly pension contribution. Differently, annual windfall income has a quite small and insignificant effect on own pension contribution. The age of the household head has a significant positive relationship with own pension contribution, at the 0.01 significance level. Since the coefficient of age-square is significant negative, the conclusion is that there is a nonlinear relationship between age and own pension contribution, and the positive effect of age on own pension contribution declines as age increases.

Comparing to full-time employment, part-time employment, unemployment and retired have significant negative relationships with own pension contribution. For example, when the household head becomes part-time employed, his/her own monthly pension contribution will decrease by $28 \%$, at the 0.01 significance level. Other factors such as family size, marital status and living in East Germany have no significant 
relationships with own pension contribution. Furthermore, the year dummies from 2007 to 2009 have significant negative effects on own monthly pension contribution in two specifications. Coefficents of year dummies will not be reported in the following tables.

I should note that the retirement system in Germany is different from the Social Security System in America. For example, the German pension system has early effective retirement ages and also high effective replacement rates, and is regarded as one of the most generous systems in the world (Börsch-Supan and Wilke, 2004). 
Table 5.5: MI estimates of a fixed-effects model for saving behaviors

\begin{tabular}{|c|c|c|c|c|}
\hline \multirow{2}{*}{ Dependent variables: } & \multicolumn{2}{|c|}{ Log(Savings out of windfall) } & \multicolumn{2}{|c|}{ Log(Annual savings) } \\
\hline & $(1)$ & $(2)$ & (1) & $(2)$ \\
\hline \multirow[t]{2}{*}{ PFA $(=1)$} & $0.134 * *$ & $0.136 * *$ & $0.225 * * *$ & $0.222 * * *$ \\
\hline & $(0.062)$ & $(0.061)$ & $(0.086)$ & $(0.086)$ \\
\hline \multirow[t]{2}{*}{ Self-control (aggregate) } & 0.048 & 0.055 & $1.566 * * *$ & $1.559 * * *$ \\
\hline & $(0.044)$ & $(0.047)$ & $(0.065)$ & $(0.071)$ \\
\hline \multirow[t]{2}{*}{ PFA*Self-control } & & -0.021 & & 0.023 \\
\hline & & $(0.060)$ & & $(0.084)$ \\
\hline \multirow[t]{2}{*}{ Non-professional advice $(=1)$} & 0.033 & 0.033 & 0.034 & 0.033 \\
\hline & $(0.064)$ & $(0.064)$ & $(0.089)$ & $(0.089)$ \\
\hline \multirow[t]{2}{*}{ Log(Total monthly income) } & 0.026 & 0.026 & $0.278 * * *$ & $0.279 * * *$ \\
\hline & $(0.048)$ & $(0.048)$ & $(0.065)$ & $(0.065)$ \\
\hline \multirow[t]{2}{*}{$\log$ (Annual windfall income) } & $0.475 * * *$ & $0.475 * * *$ & $0.044 * * *$ & $0.044 * * *$ \\
\hline & $(0.007)$ & $(0.007)$ & $(0.011)$ & $(0.011)$ \\
\hline \multirow[t]{2}{*}{ Age } & -0.058 & -0.059 & -0.050 & -0.050 \\
\hline & $(0.085)$ & $(0.085)$ & $(0.111)$ & $(0.111)$ \\
\hline \multirow[t]{2}{*}{ Age-square } & 0.032 & 0.032 & -0.108 & -0.108 \\
\hline & $(0.050)$ & $(0.050)$ & $(0.069)$ & $(0.069)$ \\
\hline \multirow[t]{2}{*}{ Own finance expectation } & -0.013 & -0.013 & $0.089 * * *$ & $0.089 * * *$ \\
\hline & $(0.015)$ & $(0.015)$ & $(0.020)$ & $(0.020)$ \\
\hline \multirow[t]{2}{*}{ Family Size } & 0.013 & 0.013 & 0.058 & 0.058 \\
\hline & $(0.046)$ & $(0.046)$ & $(0.061)$ & $(0.061)$ \\
\hline \multirow[t]{2}{*}{ Married (=1) } & 0.035 & 0.034 & $0.829 * * *$ & $0.830 * * *$ \\
\hline & $(0.203)$ & $(0.203)$ & $(0.260)$ & $(0.260)$ \\
\hline \multirow[t]{2}{*}{ Separated $(=1)$} & 0.140 & 0.139 & 0.267 & 0.268 \\
\hline & $(0.269)$ & $(0.269)$ & $(0.333)$ & $(0.333)$ \\
\hline \multirow[t]{2}{*}{ Divorced (=1) } & -0.040 & -0.040 & 0.231 & 0.231 \\
\hline & $(0.276)$ & $(0.276)$ & $(0.339)$ & $(0.340)$ \\
\hline \multirow[t]{2}{*}{ Widowed (=1) } & 0.090 & 0.088 & 0.078 & 0.080 \\
\hline & $(0.328)$ & $(0.329)$ & $(0.466)$ & $(0.466)$ \\
\hline \multirow[t]{2}{*}{ Part-time employed $(=1)$} & -0.043 & -0.043 & $-0.652 * * *$ & $-0.651 * * *$ \\
\hline & $(0.133)$ & $(0.133)$ & $(0.168)$ & $(0.168)$ \\
\hline \multirow[t]{2}{*}{ Unemployed $(=1)$} & -0.006 & -0.007 & $-0.441 * * *$ & $-0.440 * * *$ \\
\hline & $(0.129)$ & $(0.130)$ & $(0.169)$ & $(0.169)$ \\
\hline \multirow[t]{2}{*}{ Retired $(=1)$} & 0.000 & -0.000 & -0.212 & -0.212 \\
\hline & $(0.165)$ & $(0.165)$ & $(0.230)$ & $(0.230)$ \\
\hline \multirow[t]{2}{*}{ Save for emergency } & -0.000 & -0.000 & $0.032 * *$ & $0.032 * *$ \\
\hline & $(0.011)$ & $(0.011)$ & $(0.016)$ & $(0.016)$ \\
\hline \multirow[t]{2}{*}{ Save for old-age provision } & -0.000 & -0.000 & -0.016 & -0.016 \\
\hline & $(0.012)$ & $(0.012)$ & $(0.015)$ & $(0.015)$ \\
\hline Save for children education & 0.014 & 0.014 & $0.069 * * *$ & $0.069 * * *$ \\
\hline & $(0.012)$ & $(0.012)$ & $(0.016)$ & $(0.016)$ \\
\hline Save for bequests & -0.005 & -0.005 & $-0.066 * * *$ & $-0.066 * * *$ \\
\hline & $(0.008)$ & $(0.008)$ & $(0.014)$ & $(0.014)$ \\
\hline Constant & 1.917 & 1.937 & 6.798 & 6.777 \\
\hline & $(3.717)$ & $(3.721)$ & $(4.746)$ & $(4.752)$ \\
\hline Time dummies & Yes & Yes & Yes & Yes \\
\hline $\mathrm{N}$ of observations & 13,538 & 13,538 & 13,538 & 13,538 \\
\hline $\mathrm{N}$ of households & 3,940 & 3,940 & 3,940 & 3,940 \\
\hline
\end{tabular}


Table 5.6: MI estimates of a fixed-effects model for saving behaviors

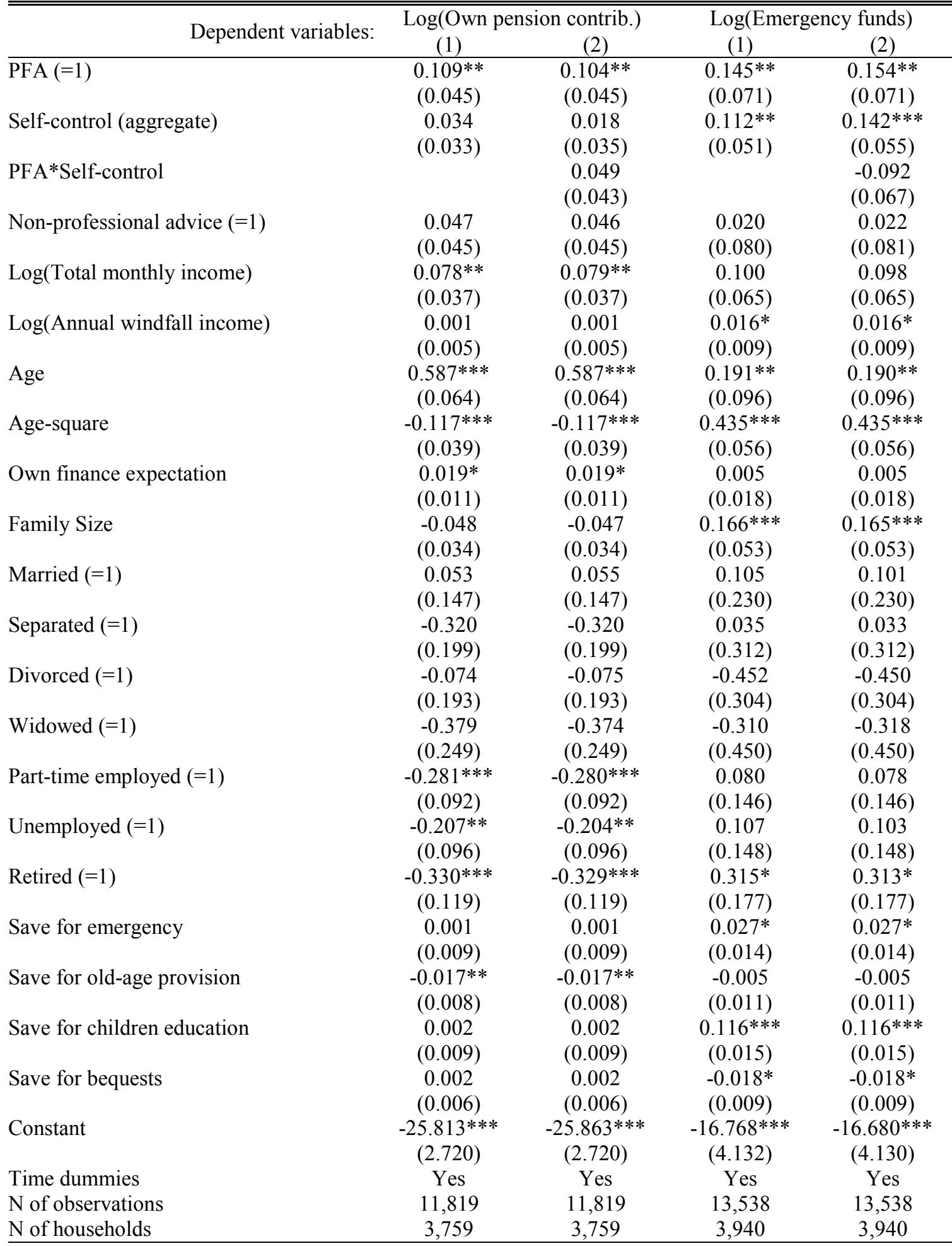

Note: The variations in sample sizes among different regressions are due to the missing values in the dependent variables. $* * *$ denotes coefficients significant at $1 \%$ level, $* *$ denotes coefficients significant at $5 \%$ level, and $*$ denotes coefficients significant at $10 \%$ level. 
Table 5.7: MI estimates of a fixed-effects model for saving behaviors

\begin{tabular}{|c|c|c|c|c|}
\hline \multirow{2}{*}{ Dependent variables: } & \multicolumn{2}{|c|}{ Log(Financial assets) } & \multicolumn{2}{|c|}{ Log(Illiquid assets) } \\
\hline & (1) & (2) & $(1)$ & $(2)$ \\
\hline \multirow[t]{2}{*}{ PFA $(=1)$} & $0.281 * * *$ & $0.295 * * *$ & $0.252 * *$ & $0.252 * *$ \\
\hline & $(0.081)$ & $(0.082)$ & $(0.100)$ & $(0.100)$ \\
\hline \multirow[t]{2}{*}{ Self-control (aggregate) } & $0.335 * * *$ & $0.377 * * *$ & 0.030 & 0.031 \\
\hline & $(0.056)$ & $(0.061)$ & $(0.078)$ & $(0.084)$ \\
\hline \multirow[t]{2}{*}{ PFA*Self-control } & & $-0.130 *$ & & -0.002 \\
\hline & & $(0.073)$ & & $(0.093)$ \\
\hline \multirow[t]{2}{*}{ Non-professional advice $(=1)$} & $0.147^{*}$ & $0.149 * *$ & -0.000 & -0.000 \\
\hline & $(0.076)$ & $(0.076)$ & $(0.105)$ & $(0.105)$ \\
\hline \multirow[t]{2}{*}{ Log(total monthly income) } & $0.216 * * *$ & $0.214 * * *$ & $0.322 * * *$ & $0.322 * * *$ \\
\hline & $(0.063)$ & $(0.063)$ & $(0.084)$ & $(0.084)$ \\
\hline \multirow[t]{2}{*}{ Log(annual windfall income) } & $0.031 * * *$ & $0.032 * * *$ & 0.007 & 0.007 \\
\hline & $(0.010)$ & $(0.010)$ & $(0.012)$ & $(0.012)$ \\
\hline \multirow[t]{2}{*}{ Age } & $-0.288 * * *$ & $-0.290 * * *$ & 0.031 & 0.031 \\
\hline & $(0.109)$ & $(0.109)$ & $(0.138)$ & $(0.139)$ \\
\hline \multirow[t]{2}{*}{ Age-square } & -0.049 & -0.049 & $0.564 * * *$ & $0.564 * * *$ \\
\hline & $(0.067)$ & $(0.067)$ & $(0.083)$ & $(0.083)$ \\
\hline \multirow[t]{2}{*}{ Own finance expectation } & $0.105 * * *$ & $0.105 * * *$ & 0.035 & 0.035 \\
\hline & $(0.019)$ & $(0.019)$ & $(0.024)$ & $(0.024)$ \\
\hline \multirow[t]{2}{*}{ Family Size } & $0.142 * *$ & $0.141 * *$ & 0.123 & 0.123 \\
\hline & $(0.062)$ & $(0.062)$ & $(0.077)$ & $(0.077)$ \\
\hline \multirow[t]{2}{*}{ Married (=1) } & -0.206 & -0.212 & -0.319 & -0.319 \\
\hline & $(0.271)$ & $(0.271)$ & $(0.323)$ & $(0.323)$ \\
\hline \multirow[t]{2}{*}{ Separated $(=1)$} & $-0.814 * *$ & $-0.816^{* *}$ & $-0.932 * *$ & $-0.932 * *$ \\
\hline & $(0.379)$ & $(0.380)$ & $(0.447)$ & $(0.447)$ \\
\hline \multirow[t]{2}{*}{ Divorced (=1) } & -0.557 & -0.554 & $-0.979 * *$ & $-0.979 * *$ \\
\hline & $(0.368)$ & $(0.368)$ & $(0.474)$ & $(0.474)$ \\
\hline \multirow[t]{2}{*}{ Widowed (=1) } & -0.392 & -0.404 & -0.861 & -0.861 \\
\hline & $(0.428)$ & $(0.427)$ & $(0.597)$ & $(0.596)$ \\
\hline \multirow[t]{2}{*}{ Part-time employed $(=1)$} & 0.202 & 0.199 & 0.077 & 0.077 \\
\hline & $(0.169)$ & $(0.169)$ & $(0.221)$ & $(0.221)$ \\
\hline \multirow[t]{2}{*}{ Unemployed $(=1)$} & 0.223 & 0.218 & 0.001 & 0.001 \\
\hline & $(0.169)$ & $(0.169)$ & $(0.214)$ & $(0.214)$ \\
\hline \multirow[t]{2}{*}{ Retired $(=1)$} & -0.030 & -0.032 & 0.054 & 0.054 \\
\hline & $(0.206)$ & $(0.206)$ & $(0.259)$ & $(0.259)$ \\
\hline \multirow[t]{2}{*}{ Save for emergency } & 0.019 & 0.019 & 0.017 & 0.017 \\
\hline & $(0.015)$ & $(0.015)$ & $(0.019)$ & $(0.019)$ \\
\hline \multirow[t]{2}{*}{ Save for vacation } & $0.038 * * *$ & $0.038 * * *$ & $0.028 *$ & $0.028 *$ \\
\hline & $(0.013)$ & $(0.013)$ & $(0.017)$ & $(0.017)$ \\
\hline Save for education & $0.040 * *$ & $0.040 * *$ & 0.032 & 0.032 \\
\hline & $(0.020)$ & $(0.020)$ & $(0.020)$ & $(0.020)$ \\
\hline Save for bequests & $-0.022 * *$ & $-0.021 * *$ & -0.002 & -0.002 \\
\hline & $(0.011)$ & $(0.011)$ & $(0.015)$ & $(0.015)$ \\
\hline Constant & $20.038 * * *$ & $20.163 * * *$ & $-17.223 * * *$ & $-17.222 * * *$ \\
\hline & $(4.683)$ & (4.681) & $(5.956)$ & $(5.957)$ \\
\hline Time dummies & Yes & Yes & Yes & Yes \\
\hline $\mathrm{N}$ of observations & 13,538 & 13,538 & 13,538 & 13,538 \\
\hline $\mathrm{N}$ of households & 3,940 & 3,940 & 3,940 & 3,940 \\
\hline
\end{tabular}


Table 5.8: MI estimates of a fixed-effects model for saving behaviors

\begin{tabular}{|c|c|c|c|c|}
\hline \multirow{2}{*}{ Dependent variables: } & \multicolumn{2}{|c|}{ Log(Total assets) } & \multicolumn{2}{|c|}{ Log(Total Loan) } \\
\hline & (1) & $(2)$ & $(1)$ & $(2)$ \\
\hline \multirow[t]{2}{*}{ PFA (=1) } & $0.208 * * *$ & $0.216 * * *$ & 0.072 & 0.088 \\
\hline & $(0.080)$ & $(0.080)$ & $(0.082)$ & $(0.082)$ \\
\hline \multirow[t]{2}{*}{ Self-control (aggregate) } & $0.231 * * *$ & $0.253 * * *$ & $-0.201 * * *$ & $-0.152 * *$ \\
\hline & $(0.054)$ & $(0.058)$ & $(0.058)$ & $(0.065)$ \\
\hline \multirow[t]{2}{*}{ PFA*Self-control } & & -0.067 & & $-0.152 *$ \\
\hline & & $(0.070)$ & & $(0.080)$ \\
\hline \multirow[t]{2}{*}{ Non-professional advice $(=1)$} & 0.044 & 0.045 & $0.149 *$ & $0.152 *$ \\
\hline & $(0.074)$ & $(0.075)$ & $(0.080)$ & $(0.080)$ \\
\hline \multirow[t]{2}{*}{ Log(total monthly income) } & $0.211 * * *$ & $0.210 * * *$ & $0.121 *$ & $0.118^{*}$ \\
\hline & $(0.061)$ & $(0.061)$ & $(0.065)$ & $(0.065)$ \\
\hline \multirow[t]{2}{*}{ Log(annual windfall income) } & $0.018 * *$ & $0.018 * *$ & $0.022 * *$ & $0.022 * *$ \\
\hline & $(0.009)$ & $(0.009)$ & $(0.009)$ & $(0.009)$ \\
\hline \multirow[t]{2}{*}{ Age } & -0.017 & -0.018 & 0.170 & 0.168 \\
\hline & $(0.106)$ & $(0.106)$ & $(0.112)$ & $(0.112)$ \\
\hline \multirow[t]{2}{*}{ Age-square } & -0.011 & -0.010 & $-0.217 * * *$ & $-0.216 * * *$ \\
\hline & $(0.065)$ & $(0.065)$ & $(0.068)$ & $(0.068)$ \\
\hline \multirow[t]{2}{*}{ Own finance expectation } & $0.087 * * *$ & $0.087 * * *$ & $-0.043 * *$ & $-0.043 * *$ \\
\hline & $(0.018)$ & $(0.018)$ & $(0.019)$ & $(0.019)$ \\
\hline \multirow[t]{2}{*}{ Family Size } & $0.135 * *$ & $0.134 * *$ & 0.074 & 0.074 \\
\hline & $(0.055)$ & $(0.055)$ & $(0.061)$ & $(0.061)$ \\
\hline \multirow[t]{2}{*}{ Married (=1) } & -0.310 & -0.313 & $0.741 * * *$ & $0.734 * * *$ \\
\hline & $(0.237)$ & $(0.237)$ & $(0.258)$ & $(0.259)$ \\
\hline \multirow[t]{2}{*}{ Separated $(=1)$} & $-0.650 * *$ & $-0.652 * *$ & 0.561 & 0.559 \\
\hline & $(0.326)$ & $(0.326)$ & $(0.344)$ & $(0.344)$ \\
\hline \multirow[t]{2}{*}{ Divorced (=1) } & $-0.638 *$ & $-0.637^{*}$ & 0.468 & 0.471 \\
\hline & $(0.333)$ & $(0.334)$ & $(0.337)$ & $(0.337)$ \\
\hline \multirow[t]{2}{*}{ Widowed (=1) } & $-0.709 *$ & $-0.715^{*}$ & 0.654 & 0.640 \\
\hline & $(0.399)$ & $(0.399)$ & $(0.438)$ & $(0.437)$ \\
\hline \multirow[t]{2}{*}{ Part-time employed $(=1)$} & 0.169 & 0.168 & $-0.315^{*}$ & $-0.319 *$ \\
\hline & $(0.166)$ & $(0.166)$ & $(0.166)$ & $(0.166)$ \\
\hline \multirow[t]{2}{*}{ Unemployed $(=1)$} & 0.222 & 0.220 & -0.268 & -0.274 \\
\hline & $(0.163)$ & $(0.163)$ & $(0.170)$ & $(0.170)$ \\
\hline \multirow[t]{2}{*}{ Retired $(=1)$} & 0.133 & 0.132 & -0.041 & -0.044 \\
\hline & $(0.194)$ & $(0.194)$ & $(0.219)$ & $(0.219)$ \\
\hline \multirow[t]{2}{*}{ Save for emergency } & 0.017 & 0.017 & 0.007 & 0.007 \\
\hline & $(0.016)$ & $(0.016)$ & $(0.015)$ & $(0.015)$ \\
\hline \multirow[t]{2}{*}{ Save for vacation } & $0.032 * * *$ & $0.032 * * *$ & -0.006 & -0.006 \\
\hline & $(0.012)$ & $(0.012)$ & $(0.016)$ & $(0.016)$ \\
\hline \multirow[t]{2}{*}{ Save for education } & $0.029 *$ & $0.029 *$ & -0.020 & -0.020 \\
\hline & $(0.015)$ & $(0.015)$ & $(0.015)$ & $(0.015)$ \\
\hline Save for bequests & -0.015 & -0.015 & $0.107 * * *$ & $0.108 * * *$ \\
\hline & $(0.010)$ & $(0.010)$ & $(0.011)$ & $(0.011)$ \\
\hline Constant & 6.079 & 6.144 & -0.086 & 0.060 \\
\hline & $(4.478)$ & $(4.476)$ & $(4.807)$ & $(4.804)$ \\
\hline Time dummies & Yes & Yes & Yes & Yes \\
\hline $\mathrm{N}$ of observations & 13,538 & 13,538 & 13,538 & 13,538 \\
\hline $\mathrm{N}$ of households & 3,940 & 3,940 & 3,940 & 3,940 \\
\hline
\end{tabular}

Note: ${ }^{* * *}$ denotes coefficients significant at $1 \%$ level, ${ }^{* *}$ denotes coefficients significant at $5 \%$ level, and $*$ denotes coefficients significant at $10 \%$ level. 


\subsubsection{Long-run saving behaviors}

The short-run improvements in saving behaviors may lead to some long-run changes in household financial outcomes. I investigate five types of financial outcomes to identify the influence of professional financial advice on household saving behaviors in the long run.

Emergency funds

Marsden et al. (2011) find that people who have met a professional financial advisor have higher emergency fund adequacy than those who have not met a financial advisor. They define emergency fund adequacy as a category variable: $=0$ if no emergency fund, $=1$ if the emergency fund is less than two months income, $=2$ if emergency fund is more than two months and less than annual income, $=3$ if emergency funds is more than the annual income. However, they do not provide the marginal effect of professional financial advice on emergency funds.

In the first specification, both PFA and self-control have a significant positive relationship with emergency-funds savings. When one household changes from no-PFA to getting PFA, their emergency-funds savings is estimated to increase by $15.6 \%$, at the 0.05 significance level. Controlling other conditions, one unit increase in self-control can lead to $11.9 \%$ increase in emergency-funds savings, at the 0.05 significance level. These results support the first and second hypotheses from the theoretical model. In the second specification, the interaction term of PFA and self-control has a negative but insignificant effect on emergency-funds savings. 
Moreover, annual total windfall has a significant positive relationship with emergency-funds in two specifications, at the 0.1 significance level. The household head's age and age-square have a significant positive relationship with emergency-funds savings. This means that households prepare more emergency funds as they age, and the increasing rate of emergency funds also increases over time. One unit increase in family size will lead to $18 \%$ increase in emergency funds.

Among saving reasons, the precautionary motive has a significant positive relationship with emergency-funds savings. When the importance of precautionary saving motive increases by one unit in the $0-10$ scale, emergency funds will increase by $2.7 \%$, at the 0.1 significance level. Comparing to precautionary saving motive, professional financial advice has a more significant and substantial relationship with emergency funds. Even if households' precautionary saving motivation is not strong, meeting a professional financial advisor can help people increase their emergency funds savings. In two specifications, year dummies in 2007, 2008, and 2009 have significant negative relationship with emergency funds.

Financial assets

In the literature, some empirical studies examine the effect of professional financial advice on household investment behavior (Kramer, 2012). Professional financial advisors can help individual investors enhance portfolio diversification (Bluethgen et al., 2008). Foerster et al. (2014) find no added value in investment suggestions from financial advisors. My study will examine the effect of professional financial advice on households' financial assets. 
In the first specifications, both professional financial advice and self-control have significant positive relationship with financial assets. When households get professional financial advice, their financial assets will increase by $32.4 \%$ at the 0.01 significance level, holding other conditions constant. One unit increase in the aggregate self-control measure can lead to $39.8 \%$ increase in financial assets.

In the second specification, the interaction term of professional financial advice and self-control has a significant negative relationship with financial assets, at the 0.1 significance level. This means that among households who get PFA, the influence of PFA on their financial assets is higher for those with lower levels of self-control than for those with higher levels of self-control. For example, for one household with a value of -0.5 in self-control, the estimated increase in their financial assets is $43 \%$ after getting PFA. For one household with a value of 0.5 in self-control, the estimated increase in their financial assets is only $26 \%$ after getting PFA. This finding supports the third hypothesis, which predicts that the effect of PFA on savings is larger for households with lower levels of self-control than for those with higher levels of self-control.

Moreover, non-professional financial advice has a significant positive relationship with financial assets. Holding other conditions, getting non-professional financial advice can increase financial assets by $16 \%$ at the 0.05 significance level. A $10 \%$ increase in household monthly income will increase financial assets by $2.16 \%$ at the 0.01 significance level. A $10 \%$ increase in the annual windfall income will increase financial assets by $0.31 \%$ at the 0.01 significance level. The expectation of own financial situation has a significant positive relationship with financial assets. One unit increase in the expectation of own finance is related with $11 \%$ increase in financial assets, at the 0.01 
significance level. Among saving reasons, saving for vacations and saving for children's education have a significant positive relationship with financial assets, while saving for bequest has a significant negative relationship with financial assets. For example, one unit increase in the importance of saving for children's education is related with $4 \%$ increase in financial assets, at the 0.01 significance level. Moreover, the year dummies from 2007 to 2009 have significant positive effects on financial assets in two specifications.

Illiquid assets

In the literature of inconsistent preference, illiquid assets are proposed as natural commitment devices for people with self-control problems (Angeletos et al., 2001). Therefore, professional financial advisors may recommend illiquid assets to households with self-control problems. In two specifications, professional financial advice has a significant positive relationship with household illiquid assets. Holding other conditions constant, getting professional financial advice will increase illiquid assets by $28.7 \%$, at the 0.01 significance level. This finding supports the first hypothesis.

Since illiquid assets are difficult to convert into cash, economists suggest that people who are conscious of their potential self-control problems may hold a larger proportion of illiquid assets in total assets in order to avoid current temptations (Laibson, 1997). However, empirical results in this study show that self-control and its interaction with professional financial advice have a very small and insignificant relationship with illiquid assets. 
The positive relationship between household monthly income and illiquid assets is significant. A $10 \%$ increase in monthly income will increase illiquid assets by $3.22 \%$, at the 0.01 significance level. The windfall income has no significant effect on illiquid assets. Moreover, expectation of own finance, family size and employment status have no significant relationship with illiquid assets in two specifications. The saving reasons have no significant relationship with illiquid assets at the 0.05 significance level. In two specifications, the dummies of year 2007, year 2008, and year 2009 have significant positive relationship with illiquid assets.

\section{Total assets}

In two specifications, both professional financial advice and self-control have a significant positive relationship with total assets. Holding other conditions constant, getting professional financial advice will increase total assets by $23 \%$ at the 0.01 significance level in the first specification. Controlling other conditions, one unit increase in the aggregate measure of self-control can lead to $26 \%$ increase in total assets in the first specification and $28.8 \%$ increase in total assets in the second specification, at the 0.01 significance level. These results support the first and second hypotheses from the theoretical model. The interaction term of PFA and self-control has an insignificant negative coefficient in the second specification.

The effect of total monthly income on total assets is much larger than the effect of annual windfall income. When total monthly income increases by $10 \%$, total assets are expected to increase by $2 \%$ at the 0.01 significance level. When annual windfall income increases by $10 \%$, total assets are expected to increase $0.18 \%$ at the 0.05 significance 
level. Moreover, total assets decrease significantly with negative changes in marital status, such as separate or divorce. For example, separation will lead to $48 \%$ decrease in total assets, at the 0.05 significance level. The saving motive for vacation has a significant positive relationship with total assets. When the importance of saving for vacation increases by one unit, total assets are expected to increase by $3.3 \%$ at the 0.01 significance level. Moreover, coefficients of year dummies from 2007 to 2009 are significant positive on total assets in two specifications.

\section{Total loan}

There is no significant positive relationship between professional financial advice and total loan in two specifications. However, there is a significant negative relationship between self-control and total loan. In the first specification, one unit increase in selfcontrol ability will lead to $18 \%$ decrease in total loan, at the 0.01 significance level. In the second specification, the interaction of PFA and self-control has a negative relationship with total loan at the 0.1 significance level. This finding supports the third hypothesis about the interaction of PFA and self-control on saving behaviors. For people who get professional financial advice, one unit increase in self-control will decrease their total loan by $26 \%$, at the 0.1 significance level. For people who do not get professional financial advice, one unit increase in self-control will result in $14 \%$ decrease in total loans, at the 0.05 significance level.

Non-professional financial advice from friends or colleagues will increase total loans by $16 \%$, at the 0.1 significance level. A $10 \%$ increase in monthly income will increase total loans by $1.21 \%$, at the 0.1 significance level. The expectation of own 
financial situation has a significant negative relationship with total loans, at the 0.05 level. Getting married will increase total loans by $108 \%$ at the 0.01 significance level. One unit increase in the importance of saving for bequest leads to $11 \%$ increase in total loan, at the 0.01 significance level. Other factors such as unemployment and living in East Germany have no significant relationship with total loans.

In sum, there is a significant positive relationship between professional financial advice and long-run financial outcomes, such as emergency funds, financial assets, illiquid assets and total assets. The self-control ability has a significant positive relationship with emergency funds, financial assets and total assets. These findings support the first and second hypotheses derived from the theoretical model. The interaction term of PFA and self-control has a significant negative relationship with financial assets and total loan, at the 0.1 significance level. These findings provide some evidence to support the third hypothesis.

\subsection{Robustness}

The 2009 survey does not cover two questions (self-assessed patience, budget recording) which are closely related with self-control ability. One alternative choice is to use four waves from 2005 to 2008 in this study, in order to make use of five proxies in factor analysis. Given the Great Recession in 2008, I expect that making use of the 2009 wave can make my findings more interesting and informative about the effect of professional financial advice on household savings. Therefore, the main results make use of five waves from 2005 to 2009 in this study. 
One robustness check is to do factor analysis with five proxies of self-control ability in the four waves from 2005 to 2008 , and to examine whether the new aggregate measure of self-control will change the empirical results. Since both the change in sample and the change in the aggregate measure of self-control can contribute to change in results, I will present two robustness checks. The first one is to drop the 2009 data but use the same aggregate measure of self-control, in order to examine the effect of sample change on empirical results. The second one is to use five proxies in the factor analysis to create the new aggregate measure of self-control from 2005 to 2008, in order to investigate how the new measure influences empirical results. 
Table 5.9: MI estimates of a fixed-effects model in the 2005-2008 sample

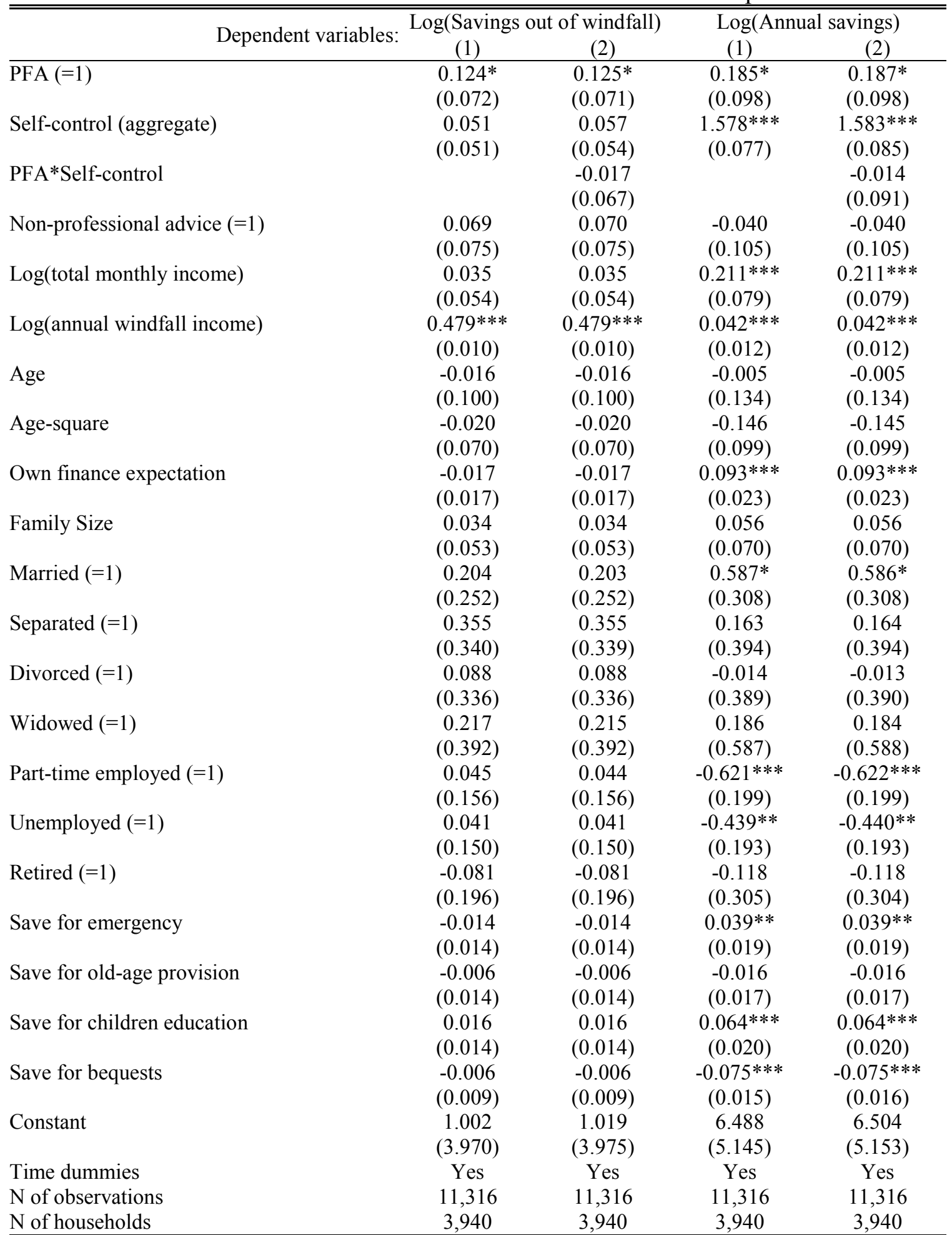

Note: $* * *$ denotes coefficients significant at $1 \%$ level, ${ }^{* *}$ denotes coefficients significant at $5 \%$ level, and $*$ denotes coefficients significant at $10 \%$ level. 
Table 5.10: MI estimates of a fixed-effects model in the 2005-2008 sample

\begin{tabular}{|c|c|c|c|c|}
\hline \multirow{2}{*}{ Dependent variables: } & \multicolumn{2}{|c|}{ Log(Own pension contrib. $)$} & \multicolumn{2}{|c|}{ Log(Emergency funds) } \\
\hline & (1) & (2) & (1) & (2) \\
\hline \multirow[t]{2}{*}{ PFA $(=1)$} & 0.068 & 0.062 & 0.078 & 0.082 \\
\hline & $(0.053)$ & $(0.053)$ & $(0.073)$ & $(0.073)$ \\
\hline \multirow[t]{2}{*}{ Self-control (aggregate) } & 0.052 & 0.030 & 0.079 & 0.093 \\
\hline & $(0.038)$ & $(0.041)$ & $(0.058)$ & $(0.061)$ \\
\hline \multirow[t]{2}{*}{ PFA*Self-control } & & 0.069 & & -0.043 \\
\hline & & $(0.051)$ & & $(0.070)$ \\
\hline \multirow[t]{2}{*}{ Non-professional advice $(=1)$} & 0.050 & 0.049 & 0.031 & 0.031 \\
\hline & $(0.053)$ & $(0.053)$ & $(0.081)$ & $(0.081)$ \\
\hline \multirow[t]{2}{*}{$\log ($ total monthly income $)$} & 0.067 & $0.068^{*}$ & $0.138 * *$ & $0.137 * *$ \\
\hline & $(0.041)$ & $(0.041)$ & $(0.060)$ & $(0.059)$ \\
\hline \multirow[t]{2}{*}{ Log(annual windfall income) } & -0.001 & -0.001 & $0.017^{*}$ & $0.017^{*}$ \\
\hline & $(0.006)$ & $(0.006)$ & $(0.009)$ & $(0.009)$ \\
\hline \multirow[t]{2}{*}{ Age } & $0.622 * * *$ & $0.623 * * *$ & $0.190^{*}$ & $0.189^{*}$ \\
\hline & $(0.076)$ & $(0.076)$ & $(0.103)$ & $(0.103)$ \\
\hline \multirow[t]{2}{*}{ Age-square } & $-0.137 * *$ & $-0.138 * *$ & $0.439 * * *$ & $0.439 * * *$ \\
\hline & $(0.054)$ & $(0.054)$ & $(0.072)$ & $(0.072)$ \\
\hline \multirow[t]{2}{*}{ Own finance expectation } & 0.016 & 0.016 & 0.014 & 0.014 \\
\hline & $(0.013)$ & $(0.013)$ & $(0.018)$ & $(0.018)$ \\
\hline \multirow[t]{2}{*}{ Family Size } & -0.054 & -0.054 & 0.072 & 0.072 \\
\hline & $(0.041)$ & $(0.041)$ & $(0.055)$ & $(0.055)$ \\
\hline \multirow[t]{2}{*}{ Married $(=1)$} & -0.113 & -0.110 & -0.049 & -0.052 \\
\hline & $(0.175)$ & $(0.174)$ & $(0.271)$ & $(0.270)$ \\
\hline \multirow{2}{*}{ Separated $(=1)$} & $-0.451^{*}$ & $-0.451^{*}$ & -0.056 & -0.057 \\
\hline & $(0.239)$ & $(0.238)$ & $(0.339)$ & $(0.339)$ \\
\hline \multirow[t]{2}{*}{ Divorced $(=1)$} & -0.239 & -0.243 & $-0.768 * *$ & $-0.766^{* *}$ \\
\hline & $(0.233)$ & $(0.232)$ & $(0.341)$ & $(0.341)$ \\
\hline \multirow[t]{2}{*}{ Widowed (=1) } & $-0.523 *$ & $-0.514 *$ & -0.575 & -0.581 \\
\hline & $(0.308)$ & $(0.308)$ & $(0.486)$ & $(0.485)$ \\
\hline \multirow[t]{2}{*}{ Part-time employed $(=1)$} & $-0.293 * * *$ & $-0.290 * * *$ & 0.204 & 0.203 \\
\hline & $(0.108)$ & $(0.108)$ & $(0.159)$ & $(0.159)$ \\
\hline \multirow[t]{2}{*}{ Unemployed $(=1)$} & $-0.187 *$ & -0.183 & 0.145 & 0.144 \\
\hline & $(0.112)$ & $(0.112)$ & $(0.161)$ & $(0.162)$ \\
\hline \multirow{2}{*}{ Retired $(=1)$} & $-0.305 * *$ & $-0.303 * *$ & $0.385^{*}$ & $0.384 *$ \\
\hline & $(0.149)$ & $(0.149)$ & $(0.206)$ & $(0.206)$ \\
\hline \multirow[t]{2}{*}{ Save for emergency } & 0.003 & 0.003 & 0.022 & 0.022 \\
\hline & $(0.010)$ & $(0.010)$ & $(0.016)$ & $(0.016)$ \\
\hline \multirow[t]{2}{*}{ Save for old-age provision } & $-0.020 * *$ & $-0.020 * *$ & -0.003 & -0.003 \\
\hline & $(0.010)$ & $(0.010)$ & $(0.012)$ & $(0.012)$ \\
\hline Save for children education & -0.001 & -0.001 & $0.111 * * *$ & $0.110 * * *$ \\
\hline & $(0.011)$ & $(0.011)$ & $(0.018)$ & $(0.018)$ \\
\hline Save for bequests & -0.001 & -0.002 & -0.014 & -0.014 \\
\hline & $(0.007)$ & $(0.007)$ & $(0.010)$ & $(0.010)$ \\
\hline Constant & $-26.801 * * *$ & $-26.864 * * *$ & $-16.826^{* * *}$ & $-16.784 * * *$ \\
\hline & $(2.916)$ & $(2.916)$ & (4.093) & $(4.091)$ \\
\hline Time dummies & Yes & Yes & Yes & Yes \\
\hline $\mathrm{N}$ of observations & 9,839 & 9,839 & 11,316 & 11,316 \\
\hline $\mathrm{N}$ of households & 3,752 & 3,752 & 3,940 & 3,940 \\
\hline
\end{tabular}

Note: $* * *$ denotes coefficients significant at $1 \%$ level, $* *$ denotes coefficients significant at $5 \%$ level, and * denotes coefficients significant at $10 \%$ level. 
Table 5.11: MI estimates of a fixed-effects model in the 2005-2008 sample

\begin{tabular}{|c|c|c|c|c|}
\hline \multirow{2}{*}{ Dependent variables: } & \multicolumn{2}{|c|}{ Log(Financial assets) } & \multicolumn{2}{|c|}{ Log(Illiquid assets) } \\
\hline & (1) & (2) & (1) & (2) \\
\hline \multirow[t]{2}{*}{ PFA $(=1)$} & $0.231 * *$ & $0.246^{* *}$ & $0.199 *$ & $0.199 *$ \\
\hline & $(0.097)$ & $(0.098)$ & $(0.119)$ & $(0.119)$ \\
\hline \multirow[t]{2}{*}{ Self-control (aggregate) } & $0.331 * * *$ & $0.377 * * *$ & 0.052 & 0.054 \\
\hline & $(0.063)$ & $(0.069)$ & $(0.088)$ & $(0.095)$ \\
\hline \multirow[t]{2}{*}{ PFA*Self-control } & & $-0.148 *$ & & -0.004 \\
\hline & & $(0.084)$ & & $(0.110)$ \\
\hline \multirow[t]{2}{*}{ Non-professional advice $(=1)$} & 0.095 & 0.097 & 0.034 & 0.034 \\
\hline & $(0.088)$ & $(0.088)$ & $(0.128)$ & $(0.128)$ \\
\hline \multirow[t]{2}{*}{$\log ($ total monthly income $)$} & $0.209 * * *$ & $0.207 * * *$ & $0.316^{* * *}$ & $0.316^{* * *}$ \\
\hline & $(0.074)$ & $(0.074)$ & $(0.100)$ & $(0.100)$ \\
\hline \multirow[t]{2}{*}{ Log(annual windfall income) } & $0.024 * *$ & $0.024 * *$ & 0.007 & 0.007 \\
\hline & $(0.011)$ & $(0.011)$ & $(0.014)$ & $(0.014)$ \\
\hline \multirow[t]{2}{*}{ Age } & $-0.235^{*}$ & $-0.238^{*}$ & -0.161 & -0.161 \\
\hline & $(0.128)$ & $(0.128)$ & $(0.167)$ & $(0.167)$ \\
\hline \multirow[t]{2}{*}{ Age-square } & -0.095 & -0.093 & $0.761 * * *$ & $0.761 * * *$ \\
\hline & $(0.093)$ & $(0.093)$ & $(0.118)$ & $(0.118)$ \\
\hline \multirow[t]{2}{*}{ Own finance expectation } & $0.122 * * *$ & $0.123 * * *$ & 0.045 & 0.045 \\
\hline & $(0.022)$ & $(0.022)$ & $(0.031)$ & $(0.031)$ \\
\hline \multirow[t]{2}{*}{ Family Size } & $0.128^{*}$ & $0.128^{*}$ & 0.089 & 0.089 \\
\hline & $(0.074)$ & $(0.074)$ & $(0.093)$ & $(0.093)$ \\
\hline \multirow[t]{2}{*}{ Married $(=1)$} & -0.181 & -0.188 & -0.409 & -0.410 \\
\hline & $(0.306)$ & $(0.306)$ & $(0.383)$ & $(0.383)$ \\
\hline \multirow{2}{*}{ Separated $(=1)$} & -0.654 & -0.654 & $-1.167 * *$ & $-1.167 * *$ \\
\hline & $(0.430)$ & $(0.431)$ & $(0.523)$ & $(0.523)$ \\
\hline \multirow[t]{2}{*}{ Divorced $(=1)$} & -0.416 & -0.410 & $-1.228 * *$ & $-1.228 * *$ \\
\hline & $(0.409)$ & $(0.409)$ & $(0.576)$ & $(0.576)$ \\
\hline \multirow[t]{2}{*}{ Widowed (=1) } & -0.200 & -0.218 & -0.740 & -0.740 \\
\hline & $(0.533)$ & $(0.532)$ & $(0.718)$ & $(0.718)$ \\
\hline \multirow[t]{2}{*}{ Part-time employed $(=1)$} & 0.267 & 0.262 & -0.065 & -0.065 \\
\hline & $(0.199)$ & $(0.199)$ & $(0.258)$ & $(0.258)$ \\
\hline \multirow{2}{*}{ Unemployed $(=1)$} & 0.213 & 0.208 & -0.011 & -0.011 \\
\hline & $(0.203)$ & $(0.203)$ & $(0.251)$ & $(0.251)$ \\
\hline \multirow[t]{2}{*}{ Retired (=1) } & -0.281 & -0.284 & -0.110 & -0.111 \\
\hline & $(0.251)$ & $(0.251)$ & $(0.344)$ & $(0.345)$ \\
\hline \multirow[t]{2}{*}{ Save for emergency } & 0.021 & 0.021 & -0.020 & -0.020 \\
\hline & $(0.017)$ & $(0.017)$ & $(0.022)$ & $(0.022)$ \\
\hline \multirow[t]{2}{*}{ Save for vacation } & $0.040^{* *}$ & $0.040 * * *$ & 0.024 & 0.024 \\
\hline & $(0.016)$ & $(0.016)$ & $(0.018)$ & $(0.018)$ \\
\hline Save for education & $0.039^{*}$ & $0.039^{*}$ & 0.033 & 0.033 \\
\hline & $(0.022)$ & $(0.022)$ & $(0.024)$ & $(0.024)$ \\
\hline Save for bequests & -0.019 & -0.019 & -0.001 & -0.001 \\
\hline & $(0.012)$ & $(0.012)$ & $(0.017)$ & $(0.017)$ \\
\hline Constant & $18.658 * * *$ & $18.806^{* * *}$ & $-12.932 * *$ & $-12.929 * *$ \\
\hline & (4.973) & (4.970) & $(6.496)$ & $(6.497)$ \\
\hline Time dummies & Yes & Yes & Yes & Yes \\
\hline $\mathrm{N}$ of observations & 11,316 & 11,316 & 11,316 & 11,316 \\
\hline $\mathrm{N}$ of households & 3,940 & 3,940 & 3,940 & 3,940 \\
\hline
\end{tabular}

Note: $* * *$ denotes coefficients significant at $1 \%$ level, $* *$ denotes coefficients significant at $5 \%$ level, and $*$ denotes coefficients significant at $10 \%$ level. 
Table 5.12: MI estimates of a fixed-effects model in the 2005-2008 sample

\begin{tabular}{|c|c|c|c|c|}
\hline \multirow{2}{*}{ Dependent variables: } & \multicolumn{2}{|c|}{ Log(Total assets) } & \multicolumn{2}{|c|}{ Log(Total Loan) } \\
\hline & (1) & (2) & (1) & (2) \\
\hline \multirow[t]{2}{*}{ PFA $(=1)$} & $0.195^{* *}$ & $0.203 * *$ & 0.078 & 0.093 \\
\hline & $(0.091)$ & $(0.091)$ & $(0.095)$ & $(0.094)$ \\
\hline \multirow[t]{2}{*}{ Self-control (aggregate) } & $0.270 * * *$ & $0.294 * * *$ & $-0.224 * * *$ & $-0.177 * *$ \\
\hline & $(0.061)$ & $(0.066)$ & $(0.065)$ & $(0.072)$ \\
\hline \multirow[t]{2}{*}{ PFA*Self-control } & & -0.078 & & $-0.151^{*}$ \\
\hline & & $(0.083)$ & & $(0.091)$ \\
\hline \multirow[t]{2}{*}{ Non-professional advice $(=1)$} & 0.051 & 0.052 & 0.099 & 0.101 \\
\hline & $(0.086)$ & $(0.087)$ & $(0.089)$ & $(0.089)$ \\
\hline \multirow[t]{2}{*}{ Log(total monthly income) } & $0.175^{* *}$ & $0.174 * *$ & 0.053 & 0.051 \\
\hline & $(0.069)$ & $(0.069)$ & $(0.070)$ & $(0.070)$ \\
\hline \multirow[t]{2}{*}{ Log(annual windfall income) } & $0.018^{*}$ & $0.018^{*}$ & $0.027 * *$ & $0.027 * *$ \\
\hline & $(0.011)$ & $(0.011)$ & $(0.011)$ & $(0.011)$ \\
\hline \multirow[t]{2}{*}{ Age } & 0.045 & 0.043 & 0.113 & 0.110 \\
\hline & $(0.130)$ & $(0.130)$ & $(0.126)$ & $(0.126)$ \\
\hline \multirow[t]{2}{*}{ Age-square } & -0.072 & -0.071 & $-0.177 * *$ & $-0.176^{* *}$ \\
\hline & $(0.094)$ & $(0.094)$ & $(0.089)$ & $(0.089)$ \\
\hline \multirow{2}{*}{ Own finance expectation } & $0.094 * * *$ & $0.094 * * *$ & -0.033 & -0.033 \\
\hline & $(0.022)$ & $(0.022)$ & $(0.022)$ & $(0.022)$ \\
\hline \multirow[t]{2}{*}{ Family Size } & $0.138^{* *}$ & $0.137 * *$ & 0.052 & 0.052 \\
\hline & $(0.066)$ & $(0.067)$ & $(0.068)$ & $(0.068)$ \\
\hline \multirow{2}{*}{ Married (=1) } & -0.402 & -0.405 & $0.648^{* *}$ & $0.641 * *$ \\
\hline & $(0.281)$ & $(0.281)$ & $(0.317)$ & $(0.317)$ \\
\hline \multirow[t]{2}{*}{ Separated $(=1)$} & $-0.714 *$ & $-0.714 *$ & 0.654 & 0.654 \\
\hline & $(0.393)$ & $(0.393)$ & $(0.413)$ & $(0.412)$ \\
\hline \multirow[t]{2}{*}{ Divorced $(=1)$} & -0.653 & -0.650 & 0.501 & 0.507 \\
\hline & $(0.413)$ & $(0.414)$ & $(0.418)$ & $(0.419)$ \\
\hline \multirow[t]{2}{*}{ Widowed (=1) } & -0.520 & -0.530 & 0.813 & 0.794 \\
\hline & $(0.490)$ & $(0.490)$ & $(0.526)$ & $(0.525)$ \\
\hline \multirow[t]{2}{*}{ Part-time employed (=1) } & 0.104 & 0.101 & -0.148 & -0.153 \\
\hline & $(0.193)$ & $(0.193)$ & $(0.189)$ & $(0.189)$ \\
\hline \multirow[t]{2}{*}{ Unemployed $(=1)$} & 0.209 & 0.207 & -0.113 & -0.118 \\
\hline & $(0.190)$ & $(0.190)$ & $(0.191)$ & $(0.191)$ \\
\hline \multirow[t]{2}{*}{ Retired (=1) } & -0.201 & -0.203 & -0.123 & -0.126 \\
\hline & $(0.253)$ & $(0.253)$ & $(0.256)$ & $(0.256)$ \\
\hline \multirow[t]{2}{*}{ Save for old-age provision } & 0.019 & 0.019 & $-0.031 * *$ & $-0.031 * *$ \\
\hline & $(0.017)$ & $(0.017)$ & $(0.015)$ & $(0.015)$ \\
\hline \multirow[t]{2}{*}{ Save for vacation } & $0.032 * *$ & $0.032^{* *}$ & -0.001 & -0.000 \\
\hline & $(0.014)$ & $(0.014)$ & $(0.015)$ & $(0.015)$ \\
\hline Save for education & $0.032 *$ & $0.032 *$ & -0.022 & -0.023 \\
\hline & $(0.018)$ & $(0.018)$ & $(0.017)$ & $(0.017)$ \\
\hline Save for bequests & -0.012 & -0.012 & $0.095^{* * *}$ & $0.095^{* * *}$ \\
\hline & $(0.011)$ & $(0.011)$ & $(0.012)$ & $(0.012)$ \\
\hline Constant & 5.081 & 5.159 & 2.358 & 2.508 \\
\hline & $(4.962)$ & (4.957) & $(4.985)$ & (4.983) \\
\hline Time dummies & Yes & Yes & Yes & Yes \\
\hline $\mathrm{N}$ of observations & 11,316 & 11,316 & 11,316 & 11,316 \\
\hline $\mathrm{N}$ of households & 3,940 & 3,940 & 3,940 & 3,940 \\
\hline
\end{tabular}

Note: $* * *$ denotes coefficients significant at $1 \%$ level, ${ }^{* *}$ denotes coefficients significant at $5 \%$ level, and $*$ denotes coefficients significant at $10 \%$ level. 
Table 5.13: MI estimates of a fixed-effects model with 5 proxies for factor analysis

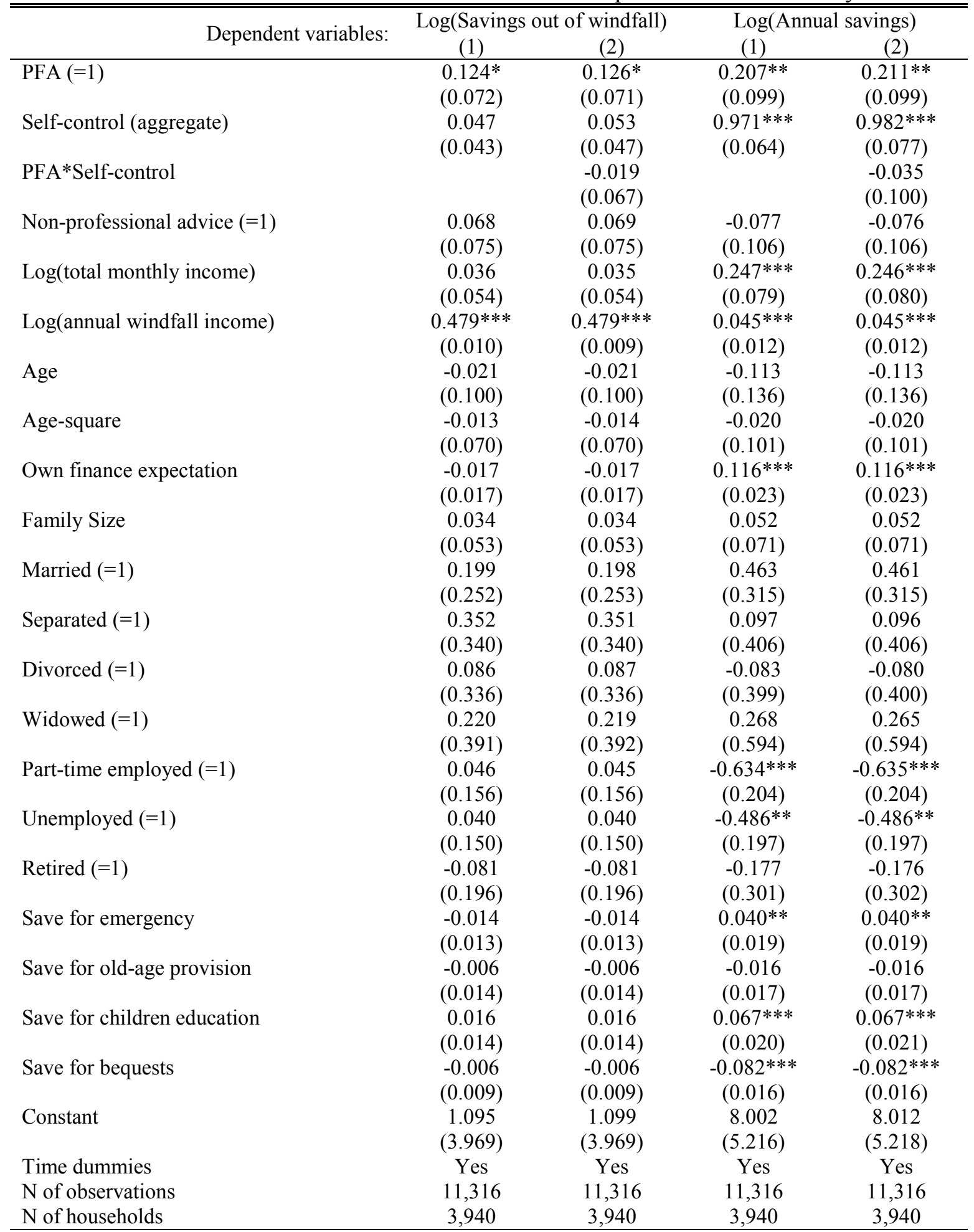

Note: $* * *$ denotes coefficients significant at $1 \%$ level, $* *$ denotes coefficients significant at $5 \%$ level, and $*$ denotes coefficients significant at $10 \%$ level. 
Table 5.14: MI estimates of a fixed-effects model with 5 proxies for factor analysis

\begin{tabular}{|c|c|c|c|c|}
\hline \multirow{2}{*}{ Dependent variables: } & \multicolumn{2}{|c|}{ Log(Own pension contrib.) } & \multicolumn{2}{|c|}{$\log ($ Emergency funds $)$} \\
\hline & (1) & (2) & (1) & (2) \\
\hline \multirow[t]{2}{*}{ PFA $(=1)$} & 0.068 & 0.060 & 0.079 & 0.091 \\
\hline & $(0.053)$ & $(0.053)$ & $(0.073)$ & $(0.073)$ \\
\hline \multirow[t]{2}{*}{ Self-control (aggregate) } & $0.067 * *$ & 0.045 & 0.010 & 0.042 \\
\hline & $(0.033)$ & $(0.036)$ & $(0.050)$ & $(0.054)$ \\
\hline \multirow[t]{2}{*}{ PFA*Self-control } & & 0.068 & & -0.101 \\
\hline & & $(0.049)$ & & $(0.065)$ \\
\hline \multirow[t]{2}{*}{ Non-professional advice $(=1)$} & 0.049 & 0.047 & 0.028 & 0.030 \\
\hline & $(0.053)$ & $(0.053)$ & $(0.081)$ & $(0.081)$ \\
\hline \multirow[t]{2}{*}{$\log ($ total monthly income $)$} & 0.067 & $0.068^{*}$ & $0.141^{* *}$ & $0.140 * *$ \\
\hline & $(0.041)$ & $(0.041)$ & $(0.059)$ & $(0.059)$ \\
\hline \multirow[t]{2}{*}{ Log(annual windfall income) } & -0.001 & -0.001 & $0.017^{*}$ & $0.017^{*}$ \\
\hline & $(0.006)$ & $(0.006)$ & $(0.009)$ & $(0.009)$ \\
\hline \multirow{2}{*}{ Age } & $0.614 * * *$ & $0.613 * * *$ & $0.189^{*}$ & $0.191^{*}$ \\
\hline & $(0.076)$ & $(0.076)$ & $(0.103)$ & $(0.103)$ \\
\hline \multirow[t]{2}{*}{ Age-square } & $-0.128 * *$ & $-0.126^{* *}$ & $0.440 * * *$ & $0.438 * * *$ \\
\hline & $(0.054)$ & $(0.054)$ & $(0.072)$ & $(0.072)$ \\
\hline \multirow[t]{2}{*}{ Own finance expectation } & 0.016 & 0.016 & 0.016 & 0.016 \\
\hline & $(0.013)$ & $(0.013)$ & $(0.018)$ & $(0.018)$ \\
\hline \multirow[t]{2}{*}{ Family Size } & -0.055 & -0.055 & 0.073 & 0.073 \\
\hline & $(0.041)$ & $(0.041)$ & $(0.055)$ & $(0.055)$ \\
\hline \multirow{2}{*}{ Married $(=1)$} & -0.119 & -0.115 & -0.053 & -0.059 \\
\hline & $(0.175)$ & $(0.175)$ & $(0.270)$ & $(0.269)$ \\
\hline \multirow[t]{2}{*}{ Separated $(=1)$} & $-0.450^{*}$ & $-0.448^{*}$ & -0.058 & -0.062 \\
\hline & $(0.238)$ & $(0.238)$ & $(0.339)$ & $(0.339)$ \\
\hline \multirow[t]{2}{*}{ Divorced (=1) } & -0.240 & -0.244 & $-0.772 * *$ & $-0.768 * *$ \\
\hline & $(0.233)$ & $(0.233)$ & $(0.340)$ & $(0.339)$ \\
\hline \multirow[t]{2}{*}{ Widowed (=1) } & $-0.520 *$ & $-0.512 *$ & -0.574 & -0.584 \\
\hline & $(0.308)$ & $(0.308)$ & $(0.487)$ & $(0.486)$ \\
\hline \multirow[t]{2}{*}{ Part-time employed (=1) } & $-0.290 * * *$ & $-0.289 * * *$ & 0.201 & 0.198 \\
\hline & $(0.108)$ & $(0.108)$ & $(0.159)$ & $(0.159)$ \\
\hline \multirow[t]{2}{*}{ Unemployed $(=1)$} & $-0.187^{*}$ & $-0.187^{*}$ & 0.142 & 0.142 \\
\hline & $(0.112)$ & $(0.112)$ & $(0.161)$ & $(0.161)$ \\
\hline \multirow[t]{2}{*}{ Retired $(=1)$} & $-0.303 * *$ & $-0.304 * *$ & $0.378^{*}$ & $0.379^{*}$ \\
\hline & $(0.149)$ & $(0.149)$ & $(0.206)$ & $(0.206)$ \\
\hline \multirow[t]{2}{*}{ Save for emergency } & 0.002 & 0.003 & 0.023 & 0.022 \\
\hline & $(0.010)$ & $(0.010)$ & $(0.016)$ & $(0.016)$ \\
\hline \multirow[t]{2}{*}{ Save for old-age provision } & $-0.020 * *$ & $-0.020 * *$ & -0.003 & -0.002 \\
\hline & $(0.010)$ & $(0.010)$ & $(0.012)$ & $(0.012)$ \\
\hline Save for children education & -0.002 & -0.001 & $0.111^{* * *}$ & $0.111^{* * *}$ \\
\hline & $(0.011)$ & $(0.011)$ & $(0.018)$ & $(0.018)$ \\
\hline Save for bequests & -0.001 & -0.002 & -0.015 & -0.015 \\
\hline & $(0.007)$ & $(0.007)$ & $(0.010)$ & $(0.010)$ \\
\hline Constant & $-26.653 * * *$ & $-26.664 * * *$ & $-16.859 * * *$ & $-16.847 * * *$ \\
\hline & $(2.914)$ & $(2.914)$ & $(4.092)$ & $(4.095)$ \\
\hline Time dummies & Yes & Yes & Yes & Yes \\
\hline $\mathrm{N}$ of observations & 9,839 & 9,839 & 11,316 & 11,316 \\
\hline $\mathrm{N}$ of households & 3,752 & 3,752 & 3,940 & 3,940 \\
\hline
\end{tabular}

Note: $* * *$ denotes coefficients significant at $1 \%$ level, $* *$ denotes coefficients significant at $5 \%$ level, and $*$ denotes coefficients significant at $10 \%$ level. 
Table 5.15: MI estimates of a fixed-effects model with 5 proxies for factor analysis

\begin{tabular}{|c|c|c|c|c|}
\hline \multirow{2}{*}{ Dependent variables: } & \multicolumn{2}{|c|}{ Log(Financial assets) } & \multicolumn{2}{|c|}{ Log(Illiquid assets) } \\
\hline & (1) & (2) & (1) & (2) \\
\hline \multirow[t]{2}{*}{ PFA $(=1)$} & $0.235^{* *}$ & $0.266 * * *$ & $0.200^{*}$ & $0.210^{*}$ \\
\hline & $(0.097)$ & $(0.098)$ & $(0.119)$ & $(0.119)$ \\
\hline \multirow[t]{2}{*}{ Self-control (aggregate) } & $0.239 * * *$ & $0.323 * * *$ & 0.024 & 0.050 \\
\hline & $(0.057)$ & $(0.064)$ & $(0.076)$ & $(0.084)$ \\
\hline \multirow[t]{2}{*}{ PFA*Self-control } & & $-0.260 * * *$ & & -0.082 \\
\hline & & $(0.087)$ & & $(0.107)$ \\
\hline \multirow[t]{2}{*}{ Non-professional advice $(=1)$} & 0.088 & 0.092 & 0.032 & 0.034 \\
\hline & $(0.088)$ & $(0.088)$ & $(0.128)$ & $(0.128)$ \\
\hline \multirow[t]{2}{*}{ Log(total monthly income) } & $0.215 * * *$ & $0.212 * * *$ & $0.317 * * *$ & $0.316 * * *$ \\
\hline & $(0.074)$ & $(0.074)$ & $(0.100)$ & $(0.100)$ \\
\hline \multirow[t]{2}{*}{ Log(annual windfall income) } & $0.024 * *$ & $0.025^{* *}$ & 0.007 & 0.007 \\
\hline & $(0.011)$ & $(0.011)$ & $(0.014)$ & $(0.014)$ \\
\hline \multirow[t]{2}{*}{ Age } & $-0.262 * *$ & $-0.258 * *$ & -0.163 & -0.162 \\
\hline & $(0.129)$ & $(0.128)$ & $(0.166)$ & $(0.166)$ \\
\hline \multirow[t]{2}{*}{ Age-square } & -0.063 & -0.069 & $0.764 * * *$ & $0.762 * * *$ \\
\hline & $(0.093)$ & $(0.093)$ & $(0.118)$ & $(0.118)$ \\
\hline \multirow[t]{2}{*}{ Own finance expectation } & $0.126^{* * *}$ & $0.127 * * *$ & 0.046 & 0.046 \\
\hline & $(0.022)$ & $(0.022)$ & $(0.030)$ & $(0.030)$ \\
\hline \multirow[t]{2}{*}{ Family Size } & $0.127^{*}$ & $0.126^{*}$ & 0.090 & 0.089 \\
\hline & $(0.074)$ & $(0.075)$ & $(0.093)$ & $(0.093)$ \\
\hline \multirow{2}{*}{ Married (=1) } & -0.208 & -0.223 & -0.413 & -0.418 \\
\hline & $(0.307)$ & $(0.306)$ & $(0.383)$ & $(0.383)$ \\
\hline \multirow[t]{2}{*}{ Separated $(=1)$} & -0.668 & -0.678 & $-1.168 * *$ & $-1.172 * *$ \\
\hline & $(0.432)$ & $(0.430)$ & $(0.522)$ & $(0.522)$ \\
\hline \multirow[t]{2}{*}{ Divorced $(=1)$} & -0.428 & -0.417 & $-1.230 * *$ & $-1.227 * *$ \\
\hline & $(0.409)$ & $(0.407)$ & $(0.576)$ & $(0.577)$ \\
\hline \multirow[t]{2}{*}{ Widowed (=1) } & -0.179 & -0.204 & -0.738 & -0.746 \\
\hline & $(0.532)$ & $(0.530)$ & $(0.718)$ & $(0.719)$ \\
\hline \multirow[t]{2}{*}{ Part-time employed (=1) } & 0.267 & 0.261 & -0.066 & -0.068 \\
\hline & $(0.199)$ & $(0.199)$ & $(0.258)$ & $(0.258)$ \\
\hline \multirow[t]{2}{*}{ Unemployed $(=1)$} & 0.204 & 0.205 & -0.013 & -0.012 \\
\hline & $(0.203)$ & $(0.203)$ & $(0.251)$ & $(0.251)$ \\
\hline \multirow[t]{2}{*}{ Retired (=1) } & -0.289 & -0.285 & -0.113 & -0.111 \\
\hline & $(0.252)$ & $(0.251)$ & $(0.344)$ & $(0.344)$ \\
\hline \multirow[t]{2}{*}{ Save for emergency } & 0.021 & 0.021 & -0.020 & -0.020 \\
\hline & $(0.017)$ & $(0.017)$ & $(0.022)$ & $(0.022)$ \\
\hline \multirow[t]{2}{*}{ Save for vacation } & $0.041 * * *$ & $0.041 * * *$ & 0.025 & 0.025 \\
\hline & $(0.016)$ & $(0.015)$ & $(0.018)$ & $(0.018)$ \\
\hline Save for education & $0.039 *$ & $0.039 *$ & 0.033 & 0.033 \\
\hline & $(0.022)$ & $(0.022)$ & $(0.024)$ & $(0.024)$ \\
\hline Save for bequests & $-0.020^{*}$ & $-0.020^{*}$ & -0.001 & -0.001 \\
\hline & $(0.012)$ & $(0.012)$ & $(0.017)$ & $(0.017)$ \\
\hline Constant & $19.070 * * *$ & $19.105^{* * *}$ & $-12.899 * *$ & $-12.891 * *$ \\
\hline & (4.977) & $(4.970)$ & $(6.494)$ & $(6.494)$ \\
\hline Time dummies & Yes & Yes & Yes & Yes \\
\hline $\mathrm{N}$ of observations & 11,316 & 11,316 & 11,316 & 11,316 \\
\hline $\mathrm{N}$ of households & 3,940 & 3,940 & 3,940 & 3,940 \\
\hline
\end{tabular}

Note: $* * *$ denotes coefficients significant at $1 \%$ level, ${ }^{* *}$ denotes coefficients significant at $5 \%$ level, and $*$ denotes coefficients significant at $10 \%$ level. 
Table 5.16: MI estimates of a fixed-effects model with 5 proxies for factor analysis

\begin{tabular}{|c|c|c|c|c|}
\hline \multirow{2}{*}{ Dependent variables: } & \multicolumn{2}{|c|}{ Log(Total assets) } & \multicolumn{2}{|c|}{ Log(Total Loan) } \\
\hline & (1) & (2) & (1) & (2) \\
\hline \multirow[t]{2}{*}{ PFA $(=1)$} & $0.198^{* *}$ & $0.209 * *$ & 0.074 & 0.093 \\
\hline & $(0.090)$ & $(0.092)$ & $(0.095)$ & $(0.096)$ \\
\hline \multirow[t]{2}{*}{ Self-control (aggregate) } & $0.210 * * *$ & $0.239 * * *$ & $-0.101 *$ & -0.052 \\
\hline & $(0.052)$ & $(0.059)$ & $(0.056)$ & $(0.064)$ \\
\hline \multirow[t]{2}{*}{ PFA*Self-control } & & -0.090 & & $-0.153^{*}$ \\
\hline & & $(0.085)$ & & $(0.085)$ \\
\hline \multirow[t]{2}{*}{ Non-professional advice $(=1)$} & 0.045 & 0.046 & 0.105 & 0.108 \\
\hline & $(0.086)$ & $(0.086)$ & $(0.088)$ & $(0.089)$ \\
\hline \multirow[t]{2}{*}{$\log ($ total monthly income) } & $0.179 * * *$ & $0.178 * * *$ & 0.046 & 0.044 \\
\hline & $(0.069)$ & $(0.069)$ & $(0.070)$ & $(0.070)$ \\
\hline \multirow[t]{2}{*}{ Log(annual windfall income) } & $0.019^{*}$ & $0.019^{*}$ & $0.026^{* *}$ & $0.027 * *$ \\
\hline & $(0.011)$ & $(0.011)$ & $(0.011)$ & $(0.011)$ \\
\hline \multirow[t]{2}{*}{ Age } & 0.021 & 0.022 & 0.124 & 0.126 \\
\hline & $(0.130)$ & $(0.130)$ & $(0.127)$ & $(0.127)$ \\
\hline \multirow[t]{2}{*}{ Age-square } & -0.044 & -0.046 & $-0.190 * *$ & $-0.193 * *$ \\
\hline & $(0.094)$ & $(0.094)$ & $(0.089)$ & $(0.090)$ \\
\hline \multirow{2}{*}{ Own finance expectation } & $0.097 * * *$ & $0.097 * * *$ & $-0.037^{*}$ & $-0.037^{*}$ \\
\hline & $(0.022)$ & $(0.022)$ & $(0.022)$ & $(0.022)$ \\
\hline \multirow[t]{2}{*}{ Family Size } & $0.136^{* *}$ & $0.136^{* *}$ & 0.052 & 0.051 \\
\hline & $(0.066)$ & $(0.066)$ & $(0.068)$ & $(0.068)$ \\
\hline \multirow{2}{*}{ Married $(=1)$} & -0.425 & -0.431 & $0.663 * *$ & $0.654 * *$ \\
\hline & $(0.281)$ & $(0.281)$ & $(0.317)$ & $(0.317)$ \\
\hline \multirow[t]{2}{*}{ Separated $(=1)$} & $-0.726^{*}$ & $-0.730^{*}$ & 0.662 & 0.656 \\
\hline & $(0.394)$ & $(0.394)$ & $(0.414)$ & $(0.413)$ \\
\hline \multirow[t]{2}{*}{ Divorced $(=1)$} & -0.663 & -0.659 & 0.512 & 0.518 \\
\hline & $(0.413)$ & $(0.414)$ & $(0.418)$ & $(0.419)$ \\
\hline \multirow[t]{2}{*}{ Widowed (=1) } & -0.502 & -0.511 & 0.804 & 0.789 \\
\hline & $(0.490)$ & $(0.491)$ & $(0.527)$ & $(0.526)$ \\
\hline \multirow[t]{2}{*}{ Part-time employed (=1) } & 0.105 & 0.103 & -0.143 & -0.146 \\
\hline & $(0.193)$ & $(0.193)$ & $(0.189)$ & $(0.189)$ \\
\hline \multirow[t]{2}{*}{ Unemployed $(=1)$} & 0.202 & 0.203 & -0.105 & -0.105 \\
\hline & $(0.190)$ & $(0.190)$ & $(0.191)$ & $(0.191)$ \\
\hline \multirow[t]{2}{*}{ Retired $(=1)$} & -0.206 & -0.205 & -0.110 & -0.108 \\
\hline & $(0.253)$ & $(0.253)$ & $(0.256)$ & $(0.256)$ \\
\hline \multirow[t]{2}{*}{ Save for old-age provision } & 0.019 & 0.019 & $-0.031 * *$ & $-0.031 * *$ \\
\hline & $(0.017)$ & $(0.017)$ & $(0.015)$ & $(0.015)$ \\
\hline \multirow[t]{2}{*}{ Save for vacation } & $0.033^{* *}$ & $0.033^{* *}$ & -0.001 & -0.001 \\
\hline & $(0.014)$ & $(0.014)$ & $(0.015)$ & $(0.015)$ \\
\hline Save for education & $0.032 *$ & $0.032 *$ & -0.023 & -0.024 \\
\hline & $(0.018)$ & $(0.018)$ & $(0.017)$ & $(0.017)$ \\
\hline Save for bequests & -0.013 & -0.013 & $0.096^{* * *}$ & $0.097^{* * *}$ \\
\hline & $(0.011)$ & $(0.011)$ & $(0.012)$ & $(0.012)$ \\
\hline Constant & 5.466 & 5.476 & 2.247 & 2.268 \\
\hline & (4.969) & $(4.965)$ & $(5.001)$ & $(5.002)$ \\
\hline Time dummies & Yes & Yes & Yes & Yes \\
\hline $\mathrm{N}$ of observations & 11,316 & 11,316 & 11,316 & 11,316 \\
\hline $\mathrm{N}$ of households & 3,940 & 3,940 & 3,940 & 3,940 \\
\hline
\end{tabular}

Note: $* * *$ denotes coefficients significant at $1 \%$ level, $* *$ denotes coefficients significant at $5 \%$ level, and * denotes coefficients significant at $10 \%$ level. 


\subsubsection{Using the 2005-2008 sample}

With the same measure of self-control, Table 5.9 to Table 5.12 present the multiple imputation estimates in the 2005-2008 sample. Comparing to empirical results in Table 5.5 to Table 5.8, the positive relationship between professional financial advice (PFA) and saving behaviors becomes less significant after dropping the 2009 wave. For example, the significant positive effects of PFA on own pension contribution in Table 5.6 and on emergency funds in Table 5.7 becomes insignificant in Table 5.10 and Table 5.11 . At the same time, the coefficients of PFA become smaller after dropping the 2009 wave. Similar patterns are found by comparing the effects of self-control with and without the 2009 wave. The interaction term of PFA and self-control has negative effects on financial assets and total loan, at the 0.1 significance level.

In sum, the 2005-2008 sample can provide less significant results to support the three hypotheses in this study than the 2005-2009 sample. Therefore, the change in sample has substantial influences on empirical results about the effects of PFA and selfcontrol on saving behaviors.

\subsubsection{Using more proxies in factor analysis}

The surveys from 2005 to 2008 ask respondents to assess their own patience (or impatience) and to report their budgeting behavior. Since these two variables are closely related with self-control, I add them as two more proxies for self-control in factor analysis. Therefore, five proxies will be used in factor analysis to create an aggregate 
measure of self-control ability: self-assessed patience, budgeting, saving habit, not smoking, and less overdraw.

\section{Self-Assessed Patience}

Similar to the NLSY assessment of impatience used in DellaVigna and Paserman (2006), I make use of the self-assessed patience in SAVE as a proxy for the self-control ability. From 2005 to 2006, higher scores in two self-assessed questions represent more patience, on a scale from 0 to 10. The 2007 questionnaire adds another two questions about self-assessed impatience besides two questions about self-assessed patience. The 2008 questionnaire keeps two questions about self-assessed impatience and drops two questions about self-assessed impatience. I convert the answers of self-assessed impatience to patience by using the result of "10 minus original answers" in 2007 and 2008, and then construct a measure of self-assessed patience by taking the average of available answers in each year.

\section{Budgeting}

It takes immediate efforts to keep a record of household's income and expenditure. Oaten and Cheng (2007) show that a financial monitoring program can improve participants' laboratory measure of self-control. Heath and Soll (1996) discuss budgeting as an alternative method of self-control. I use the dummy of budget-recording as a proxy for self-control ability. 
Table 5.17: Factor analysis in the 2005-2008 sample

\begin{tabular}{lccc}
\hline \hline Behavioral measures & Factor Loadings & Uniqueness & Scoring Coefficient \\
\hline Self-reported patience & 0.2990 & 0.8570 & 0.2575 \\
Budgeting $(=1)$ & 0.1712 & 0.9696 & 0.1303 \\
Saving habit & 0.3045 & 0.9069 & 0.2478 \\
Not smoking $(=1)$ & 0.2901 & 0.8607 & 0.2487 \\
Less overdraw & 0.1415 & 0.9709 & 0.1075 \\
\hline
\end{tabular}

Note: Factor analysis is used to create an aggregate measure of self-control from five behavioral proxies of self-control ability. Entries in the table represent maximum likelihood estimates for factor analysis model.

In Table 5.17, the factor analysis via maximum likelihood retains two common factors, but only one factor with positive factor loadings with all variables. This common factor is assumed to measure the self-control ability, since no other reasons can be found to be positive related with all five variables (DellaVigna \& Paserman, 2006). The scoring coefficients will be used as weights to create the aggregate measure of self-control, which is a weighted average of the individual variables. The proxies that receive the highest weights are saving habit, self-assessed patience, and not smoking.

Using the new aggregate measure of self-control, Table 5.13 to Table 5.16 present the multiple imputation estimates in the 2005-2008 sample. Comparing to empirical results in Table 5.9 to Table 5.12, the most importance improvement is that the interaction of PFA and self-control has a larger significant negative relationship with financial assets at the 0.01 significance level, instead of at the 0.1 significance level. For one household with a value of -0.5 in self-control, the estimated increase in their financial assets is $37 \%$ after getting PFA, at the 0.01 significance level. For one household with a value of 0.5 in self-control, the estimated increase in their financial assets is only $18.8 \%$ 
after getting PFA, at the 0.01 significance level. With the new aggregate measure of selfcontrol, the interaction of PFA and self-control has a negative relationship with total loan, at the 0.1 significance level. These findings support the third hypothesis in this study.

In sum, professional financial advice has a significant positive relationship with savings out of windfall, annual total savings, financial assets, illiquid assets and total assets in both the 2005-2009 sample and the 2005-2008 sample. The self-control ability has a significant positive relationship with annual total savings, financial assets and total assets in two aggregate measures of self-control. The interaction of PFA and self-control has a significant negative relationship with financial assets and total loans, across two samples and two measures of self-control.

\subsubsection{Using the unimputed data for key variables}

Besides using the panel structure to logically impute some variables, the SAVE data center has imputed the missing values in each single variable by conditioning on as many relevant variables as possible (Schunk, 2008; Ziegelmeyer, 2009). For example, the missing values in emergency funds have been imputed conditional on demographic variables, monthly income, health behaviors, expectations, and saving reasons. The advice-seeking behaviors are not included as conditional variables in multiple imputation of emergency funds.

There are two advantages to use the imputed datasets. First, if item non-response is not random among respondents, deleting observations with missing values will lead to biased results. Second, imputed datasets can retain the sample size for analysis (Montalto \& Sung, 1996). My previous analysis has used five complete datasets of each wave in multiple imputation estimation. 
However, it is meaningful to examine whether the empirical results will change after deleting the imputed values in key variables. As the third robustness check, I have deleted the flagged imputed values for dependent variables and variables related with advice-seeking behaviors in this section. The average missing rate in seeking PFA is $3.6 \%$ from 2005 to 2009 , with the lowest missing rate $0.7 \%$ in 2005 and the highest missing rate $6.5 \%$ in 2006 . Financial variables have higher missing rates than other variables, due to privacy concerns of financial matters. The average missing rate of most financial variables is between $5 \%$ and $15 \%$ in the $2005-2009$ samples. The variable about emergency funds has a relatively high average missing rate $18.6 \%$ in the $2005-2009$ samples.

Table 5.18 to Table 5.21 present the empirical results after deleting observations with missing dependent variables or missing advice-seeking behaviors. The sample sizes have decreased accordingly. Besides the changes in coefficients, there are some small changes in the significance of PFA and self-control. However, the interaction term of PFA and self-control has become insignificant in the regressions of financial assets and total loan, while it has become significant for emergency funds. Since the average missing rate of emergency funds is relatively high, the imputed values should be the reason for the insignificant interaction term in the regression of emergency funds in Table 5.6 .

\subsubsection{Using lagged independent variables}

Most household surveys ask about the current finance situations of respondents, such as Panel Study of Income Dynamics (PSID). Differently, respondents in SAVE are asked to report their financial situation at the end of the previous year or in the December 
of the previous year, while other questions refer to the current situation or the situation in the past 12 months. The question about seeking PFA doesn't provide a clear time window to help respondents recall their advice seeking behaviors. On the other hand, the data collection of SAVE is generally conducted from March to July. Therefore, there is a limitation in survey questions about clarifying the time order of seeking PFA and financial outcomes. Some respondents may meet a professional financial advice before the end of the previous year, and some respondents may do this after the December of the previous year and before the interview date. Similarly, most independent variables in regressions also ask about the current situation of the respondents, such as marital status, own finance expectation, employment status, and saving reasons.

As the fourth robustness check, I match the information about advice-seeking behaviors in one wave and financial information in the next wave. For example, the advice-seeking behaviors in 2005 are matched with households' financial information in 2006. The advantage side of this match method is to avoid the unclear timing issue in the survey. The disadvantage side is to reduce the sample size because some households may drop out in the next wave. Given the fact that other independent variables may also have the timing issue, I use income and financial information in the next wave to match other information in the current wave. I also make use of the financial information in the 2010 wave to match the 2009 wave, in order to increase the sample size in this method.

Table 5.22 to Table 5.25 present the results in a fixed-effects model after matching across years. In 2010, there are no questions about how respondents spend their windfall income in the previous year. Therefore, the sample size in the regression about savings out of windfall is the smallest in this matching method. Since the question of 
emergency funds is about the current amount, I use the information about emergency funds in the same wave ${ }^{4}$. However, the monthly income and windfall income is about the previous year, and I have matched them across waves for all regressions. In order to keep consistent with other regressions, I also matched the income information in the regression of emergency funds. Therefore, the sample size of emergency funds also decreases in Table 5.23.

In Table 5.24, the results of financial assets support three hypotheses. Holding other conditions constant, getting PFA will increase financial assets by $18.3 \%$ at the 0.1 significance level in the first specification. In the second specification, both seeking PFA and self-control have a significant positive relationship with financial assets at the 0.05 significance level. The interaction term of PFA and self-control has a significant negative relationship with financial assets. In the results about illiquid assets, there is a significant negative relationship between self-control and illiquid assets at the 0.05 significance level. However, after adding the interaction term of PFA and self-control, such a relationship becomes insignificant.

I also examine the relationship between advice-seeking behaviors and financial variables in pooled OLS regressions with time-fixed effects in Table 5.26 to Table 5.29. Besides the previous control variables, the OLS regressions control for head gender, head's education (no high school, high school, and university), and German nationality. Moreover, I control for more detailed information of residence states instead of East Germany (=1) in OLS regressions. Results demonstrate that there is a significant positive relationship between PFA and financial outcomes. Self-control has a significant positive

\footnotetext{
${ }^{4}$ I also tried to use emergency funds in the next wave. The results are very similar with using emergency funds in the same wave.
} 
relationship with annual savings, own pension contribution, emergency funds, financial assets, illiquid assets, and total assets. The interaction term of PFA and self-control has a significant negative relationship with emergency funds, financial assets, illiquid assets, total assets and total loan. 
Table 5.18: Fixed-effects regressions by using unimputed data

\begin{tabular}{|c|c|c|c|c|}
\hline \multirow{2}{*}{ Dependent variables: } & \multicolumn{2}{|c|}{ Log(Savings out of windfall) } & \multicolumn{2}{|c|}{ Log(Annual savings) } \\
\hline & (1) & (2) & $(1)$ & (2) \\
\hline \multirow[t]{2}{*}{ PFA $(=1)$} & $0.105^{*}$ & $0.111^{*}$ & $0.220 * * *$ & $0.221 * * *$ \\
\hline & $(0.061)$ & $(0.062)$ & $(0.081)$ & $(0.082)$ \\
\hline \multirow[t]{2}{*}{ Self-control (aggregate) } & $0.213^{* *}$ & $0.249^{* *}$ & $3.992 * * *$ & $3.995^{* * *}$ \\
\hline & $(0.105)$ & $(0.114)$ & $(0.138)$ & $(0.150)$ \\
\hline \multirow[t]{2}{*}{ PFA*Self-control } & & -0.109 & & -0.009 \\
\hline & & $(0.140)$ & & $(0.185)$ \\
\hline \multirow[t]{2}{*}{ Non-prof advice $(=1)$} & 0.043 & 0.044 & 0.033 & 0.033 \\
\hline & $(0.062)$ & $(0.062)$ & $(0.082)$ & $(0.082)$ \\
\hline \multirow[t]{2}{*}{$\log ($ total monthly income) } & 0.006 & 0.005 & $0.232 * * *$ & $0.232 * * *$ \\
\hline & $(0.050)$ & $(0.050)$ & $(0.067)$ & $(0.067)$ \\
\hline \multirow[t]{2}{*}{ Log(annual windfall income) } & $0.485^{* * *}$ & $0.485^{* * *}$ & $0.040 * * *$ & $0.040 * * *$ \\
\hline & $(0.007)$ & $(0.007)$ & $(0.010)$ & $(0.010)$ \\
\hline \multirow[t]{2}{*}{ Age } & -0.106 & -0.107 & -0.067 & -0.067 \\
\hline & $(0.088)$ & $(0.088)$ & $(0.115)$ & $(0.115)$ \\
\hline \multirow[t]{2}{*}{ Age-square } & 0.040 & 0.040 & -0.100 & -0.100 \\
\hline & $(0.052)$ & $(0.052)$ & $(0.069)$ & $(0.069)$ \\
\hline \multirow[t]{2}{*}{ Own finance expectation } & -0.011 & -0.011 & $0.061 * * *$ & $0.061 * * *$ \\
\hline & $(0.015)$ & $(0.015)$ & $(0.020)$ & $(0.020)$ \\
\hline \multirow[t]{2}{*}{ Family Size } & 0.030 & 0.030 & 0.059 & 0.059 \\
\hline & $(0.047)$ & $(0.047)$ & $(0.062)$ & $(0.062)$ \\
\hline \multirow{2}{*}{ Married $(=1)$} & -0.069 & -0.072 & $0.911 * * *$ & $0.910 * * *$ \\
\hline & $(0.201)$ & $(0.202)$ & $(0.262)$ & $(0.262)$ \\
\hline \multirow[t]{2}{*}{ Separated $(=1)$} & 0.205 & 0.203 & 0.401 & 0.401 \\
\hline & $(0.270)$ & $(0.270)$ & $(0.355)$ & $(0.355)$ \\
\hline \multirow[t]{2}{*}{ Divorced (=1) } & 0.065 & 0.065 & 0.351 & 0.351 \\
\hline & $(0.271)$ & $(0.271)$ & $(0.355)$ & $(0.355)$ \\
\hline \multirow[t]{2}{*}{ Widowed (=1) } & -0.078 & -0.083 & -0.121 & -0.121 \\
\hline & $(0.344)$ & $(0.344)$ & $(0.451)$ & $(0.451)$ \\
\hline \multirow[t]{2}{*}{ Part-time employed (=1) } & -0.011 & -0.012 & $-0.715^{* * *}$ & $-0.715^{* * *}$ \\
\hline & $(0.132)$ & $(0.132)$ & $(0.173)$ & $(0.173)$ \\
\hline \multirow[t]{2}{*}{ Unemployed $(=1)$} & -0.116 & -0.118 & $-0.425 * *$ & $-0.425 * *$ \\
\hline & $(0.134)$ & $(0.134)$ & $(0.175)$ & $(0.175)$ \\
\hline \multirow[t]{2}{*}{ Retired $(=1)$} & -0.067 & -0.069 & -0.207 & -0.207 \\
\hline & $(0.164)$ & $(0.164)$ & $(0.218)$ & $(0.218)$ \\
\hline \multirow[t]{2}{*}{ Save for emergency } & 0.001 & 0.001 & 0.014 & 0.014 \\
\hline & $(0.011)$ & $(0.011)$ & $(0.014)$ & $(0.014)$ \\
\hline \multirow[t]{2}{*}{ Save for old-age provision } & 0.004 & 0.004 & -0.021 & -0.021 \\
\hline & $(0.010)$ & $(0.010)$ & $(0.014)$ & $(0.014)$ \\
\hline Save for children education & 0.012 & 0.012 & $0.047 * * *$ & $0.047 * * *$ \\
\hline & $(0.012)$ & $(0.012)$ & $(0.015)$ & $(0.015)$ \\
\hline Save for bequests & -0.009 & -0.009 & $-0.055^{* * *}$ & $-0.055^{* * *}$ \\
\hline & $(0.008)$ & $(0.008)$ & $(0.010)$ & $(0.010)$ \\
\hline Constant & 4.135 & 4.187 & 7.653 & 7.652 \\
\hline & $(3.795)$ & $(3.796)$ & (4.937) & $(4.938)$ \\
\hline Time dummies & Yes & Yes & Yes & Yes \\
\hline $\mathrm{N}$ of observations & 12,344 & 12,344 & 11,415 & 11,415 \\
\hline $\mathrm{N}$ of households & 3,888 & 3,888 & 3,747 & 3,747 \\
\hline
\end{tabular}

Note: $* * *$ denotes coefficients significant at $1 \%$ level, $* *$ denotes coefficients significant at $5 \%$ level, and $*$ denotes coefficients significant at $10 \%$ level. 
Table 5.19: Fixed-effects regressions by using unimputed data

\begin{tabular}{|c|c|c|c|c|}
\hline \multirow{2}{*}{ Dependent variables: } & \multicolumn{2}{|c|}{ Log(Own pension contrib. $)$} & \multicolumn{2}{|c|}{ Log(Emergency funds) } \\
\hline & (1) & (2) & (1) & (2) \\
\hline \multirow[t]{2}{*}{ PFA (=1) } & $0.097 * *$ & $0.091 *$ & $0.205 * * *$ & $0.226 * * *$ \\
\hline & $(0.048)$ & $(0.048)$ & $(0.075)$ & $(0.076)$ \\
\hline \multirow[t]{2}{*}{ Self-control (aggregate) } & 0.054 & 0.019 & $0.541 * * *$ & $0.666^{* * *}$ \\
\hline & $(0.081)$ & $(0.089)$ & $(0.130)$ & $(0.142)$ \\
\hline \multirow[t]{2}{*}{ PFA*Self-control } & & 0.107 & & $-0.370 * *$ \\
\hline & & $(0.108)$ & & $(0.171)$ \\
\hline \multirow[t]{2}{*}{ Non-prof advice $(=1)$} & 0.036 & 0.035 & 0.009 & 0.013 \\
\hline & $(0.048)$ & $(0.048)$ & $(0.077)$ & $(0.077)$ \\
\hline \multirow[t]{2}{*}{$\log ($ total monthly income) } & $0.072 *$ & $0.074 *$ & 0.080 & 0.078 \\
\hline & $(0.039)$ & $(0.039)$ & $(0.070)$ & $(0.070)$ \\
\hline \multirow[t]{2}{*}{ Log(annual windfall income) } & 0.007 & 0.007 & $0.024 * * *$ & $0.024 * * *$ \\
\hline & $(0.006)$ & $(0.006)$ & $(0.009)$ & $(0.009)$ \\
\hline \multirow{2}{*}{ Age } & $0.660^{* * *}$ & $0.661 * * *$ & -0.062 & -0.066 \\
\hline & $(0.069)$ & $(0.069)$ & $(0.110)$ & $(0.110)$ \\
\hline \multirow[t]{2}{*}{ Age-square } & $-0.128 * * *$ & $-0.128 * * *$ & $0.544 * * *$ & $0.544 * * *$ \\
\hline & $(0.040)$ & $(0.040)$ & $(0.064)$ & $(0.064)$ \\
\hline \multirow[t]{2}{*}{ Own finance expectation } & $0.022^{*}$ & $0.022^{*}$ & 0.018 & 0.018 \\
\hline & $(0.012)$ & $(0.012)$ & $(0.020)$ & $(0.020)$ \\
\hline \multirow[t]{2}{*}{ Family Size } & -0.049 & -0.048 & $0.199 * * *$ & $0.197 * * *$ \\
\hline & $(0.036)$ & $(0.036)$ & $(0.060)$ & $(0.060)$ \\
\hline \multirow{2}{*}{ Married $(=1)$} & 0.085 & 0.088 & 0.148 & 0.144 \\
\hline & $(0.153)$ & $(0.153)$ & $(0.248)$ & $(0.248)$ \\
\hline \multirow[t]{2}{*}{ Separated $(=1)$} & -0.265 & -0.264 & 0.127 & 0.125 \\
\hline & $(0.212)$ & $(0.212)$ & $(0.336)$ & $(0.336)$ \\
\hline \multirow[t]{2}{*}{ Divorced (=1) } & -0.116 & -0.116 & -0.420 & -0.415 \\
\hline & $(0.206)$ & $(0.206)$ & $(0.330)$ & $(0.330)$ \\
\hline \multirow[t]{2}{*}{ Widowed (=1) } & $-0.442 *$ & -0.436 & 0.048 & 0.032 \\
\hline & $(0.268)$ & $(0.268)$ & $(0.425)$ & $(0.424)$ \\
\hline \multirow[t]{2}{*}{ Part-time employed (=1) } & $-0.283 * * *$ & $-0.282^{* * *}$ & 0.078 & 0.075 \\
\hline & $(0.098)$ & $(0.098)$ & $(0.163)$ & $(0.163)$ \\
\hline \multirow[t]{2}{*}{ Unemployed $(=1)$} & -0.151 & -0.148 & 0.145 & 0.137 \\
\hline & $(0.101)$ & $(0.101)$ & $(0.165)$ & $(0.165)$ \\
\hline \multirow[t]{2}{*}{ Retired $(=1)$} & $-0.336 * * *$ & $-0.334 * * *$ & $0.525 * * *$ & $0.518 * * *$ \\
\hline & $(0.126)$ & $(0.126)$ & $(0.200)$ & $(0.200)$ \\
\hline \multirow[t]{2}{*}{ Save for emergency } & 0.001 & 0.001 & $0.033 * *$ & $0.033^{* *}$ \\
\hline & $(0.008)$ & $(0.008)$ & $(0.013)$ & $(0.013)$ \\
\hline \multirow[t]{2}{*}{ Save for old-age provision } & $-0.017 * *$ & $-0.017 * *$ & -0.002 & -0.003 \\
\hline & $(0.008)$ & $(0.008)$ & $(0.013)$ & $(0.013)$ \\
\hline Save for children education & 0.004 & 0.004 & $0.119 * * *$ & $0.119 * * *$ \\
\hline & $(0.009)$ & $(0.009)$ & $(0.015)$ & $(0.015)$ \\
\hline Save for bequests & 0.004 & 0.004 & $-0.017^{*}$ & $-0.017^{*}$ \\
\hline & $(0.006)$ & $(0.006)$ & $(0.010)$ & $(0.010)$ \\
\hline Constant & $-28.867 * * *$ & $-28.924 * * *$ & -6.913 & -6.692 \\
\hline & (2.917) & (2.918) & $(4.759)$ & $(4.759)$ \\
\hline Time dummies & Yes & Yes & Yes & Yes \\
\hline $\mathrm{N}$ of observations & 11,014 & 11,014 & 10,270 & 10,270 \\
\hline $\mathrm{N}$ of households & 3,729 & 3,729 & 3,521 & 3,521 \\
\hline
\end{tabular}

Note: $* * *$ denotes coefficients significant at $1 \%$ level, $* *$ denotes coefficients significant at $5 \%$ level, and $*$ denotes coefficients significant at $10 \%$ level. 
Table 5.20: Fixed-effects regressions by using unimputed data

\begin{tabular}{|c|c|c|c|c|}
\hline \multirow{2}{*}{ Dependent variables: } & \multicolumn{2}{|c|}{ Log(Financial assets) } & \multicolumn{2}{|c|}{ Log(Illiquid assets) } \\
\hline & (1) & (2) & (1) & (2) \\
\hline \multirow[t]{2}{*}{ PFA (=1) } & $0.312 * * *$ & $0.310 * * *$ & $0.257^{* *}$ & $0.249^{* *}$ \\
\hline & $(0.094)$ & $(0.094)$ & $(0.104)$ & $(0.105)$ \\
\hline \multirow[t]{2}{*}{ Self-control (aggregate) } & $0.663 * * *$ & $0.650 * * *$ & 0.002 & -0.047 \\
\hline & $(0.161)$ & $(0.176)$ & $(0.177)$ & $(0.194)$ \\
\hline \multirow[t]{2}{*}{ PFA*Self-control } & & 0.038 & & 0.150 \\
\hline & & $(0.214)$ & & $(0.238)$ \\
\hline \multirow[t]{2}{*}{ Non-prof advice $(=1)$} & $0.202 * *$ & $0.202 * *$ & -0.085 & -0.086 \\
\hline & $(0.095)$ & $(0.095)$ & $(0.105)$ & $(0.105)$ \\
\hline \multirow[t]{2}{*}{ Log(total monthly income) } & -0.017 & -0.017 & 0.137 & 0.138 \\
\hline & $(0.078)$ & $(0.078)$ & $(0.085)$ & $(0.085)$ \\
\hline \multirow[t]{2}{*}{ Log(annual windfall income) } & $0.040 * * *$ & $0.040 * * *$ & 0.007 & 0.007 \\
\hline & $(0.011)$ & $(0.011)$ & $(0.012)$ & $(0.012)$ \\
\hline \multirow[t]{2}{*}{ Age } & 0.019 & 0.019 & -0.093 & -0.092 \\
\hline & $(0.134)$ & $(0.134)$ & $(0.149)$ & $(0.149)$ \\
\hline \multirow[t]{2}{*}{ Age-square } & $-0.274 * * *$ & $-0.274 * * *$ & $0.411 * * *$ & $0.411 * * *$ \\
\hline & $(0.079)$ & $(0.079)$ & $(0.087)$ & $(0.087)$ \\
\hline \multirow{2}{*}{ Own finance expectation } & $0.094 * * *$ & $0.094 * * *$ & 0.031 & 0.031 \\
\hline & $(0.024)$ & $(0.024)$ & $(0.026)$ & $(0.026)$ \\
\hline \multirow[t]{2}{*}{ Family Size } & $0.125^{*}$ & $0.125^{*}$ & $0.159^{* *}$ & $0.159 * *$ \\
\hline & $(0.073)$ & $(0.073)$ & $(0.080)$ & $(0.080)$ \\
\hline \multirow{2}{*}{ Married (=1) } & -0.452 & -0.451 & -0.029 & -0.025 \\
\hline & $(0.307)$ & $(0.307)$ & $(0.340)$ & $(0.340)$ \\
\hline \multirow[t]{2}{*}{ Separated $(=1)$} & $-1.112 * * *$ & $-1.112 * * *$ & $-0.763^{*}$ & $-0.761 *$ \\
\hline & $(0.416)$ & $(0.416)$ & $(0.458)$ & $(0.458)$ \\
\hline \multirow[t]{2}{*}{ Divorced (=1) } & $-0.779 *$ & $-0.779 *$ & -0.594 & -0.593 \\
\hline & $(0.412)$ & $(0.412)$ & $(0.458)$ & $(0.458)$ \\
\hline \multirow[t]{2}{*}{ Widowed (=1) } & $-1.153 * *$ & $-1.151 * *$ & -0.418 & -0.411 \\
\hline & $(0.524)$ & $(0.524)$ & $(0.582)$ & $(0.582)$ \\
\hline \multirow[t]{2}{*}{ Part-time employed (=1) } & 0.286 & 0.287 & 0.171 & 0.172 \\
\hline & $(0.200)$ & $(0.200)$ & $(0.223)$ & $(0.223)$ \\
\hline \multirow[t]{2}{*}{ Unemployed $(=1)$} & 0.006 & 0.007 & 0.185 & 0.188 \\
\hline & $(0.204)$ & $(0.204)$ & $(0.226)$ & $(0.226)$ \\
\hline \multirow[t]{2}{*}{ Retired (=1) } & 0.023 & 0.023 & 0.380 & 0.382 \\
\hline & $(0.252)$ & $(0.252)$ & $(0.278)$ & $(0.279)$ \\
\hline \multirow[t]{2}{*}{ Save for emergency } & -0.004 & -0.004 & 0.015 & 0.015 \\
\hline & $(0.016)$ & $(0.016)$ & $(0.018)$ & $(0.018)$ \\
\hline \multirow[t]{2}{*}{ Save for old-age provision } & 0.006 & 0.006 & -0.021 & -0.021 \\
\hline & $(0.016)$ & $(0.016)$ & $(0.017)$ & $(0.017)$ \\
\hline Save for children education & $0.049 * * *$ & $0.049 * * *$ & $0.047 * *$ & $0.047 * *$ \\
\hline & $(0.018)$ & $(0.018)$ & $(0.020)$ & $(0.020)$ \\
\hline Save for bequests & -0.015 & -0.015 & $0.025^{*}$ & $0.025^{*}$ \\
\hline & $(0.012)$ & $(0.012)$ & $(0.013)$ & $(0.013)$ \\
\hline Constant & $11.680^{* *}$ & $11.659 * *$ & -6.398 & -6.491 \\
\hline & $(5.792)$ & $(5.793)$ & $(6.415)$ & $(6.416)$ \\
\hline Time dummies & Yes & Yes & Yes & Yes \\
\hline $\mathrm{N}$ of observations & 11,824 & 11,824 & 12,363 & 12,363 \\
\hline $\mathrm{N}$ of households & 3,796 & 3,796 & 3,887 & 3,887 \\
\hline
\end{tabular}

Note: $* * *$ denotes coefficients significant at $1 \%$ level, $* *$ denotes coefficients significant at $5 \%$ level, and $*$ denotes coefficients significant at $10 \%$ level. 
Table 5.21: Fixed-effects regressions by using unimputed data

\begin{tabular}{|c|c|c|c|c|}
\hline \multirow{2}{*}{ Dependent variables: } & \multicolumn{2}{|c|}{ Log(Total assets) } & \multicolumn{2}{|c|}{ Log(Total Loan) } \\
\hline & (1) & (2) & (1) & (2) \\
\hline \multirow[t]{2}{*}{ PFA $(=1)$} & 0.146 & 0.147 & 0.091 & 0.107 \\
\hline & $(0.091)$ & $(0.092)$ & $(0.084)$ & $(0.084)$ \\
\hline \multirow[t]{2}{*}{ Self-control (aggregate) } & $0.353^{* *}$ & $0.359^{* *}$ & $-0.581 * * *$ & $-0.482 * * *$ \\
\hline & $(0.156)$ & $(0.170)$ & $(0.143)$ & $(0.157)$ \\
\hline \multirow[t]{2}{*}{ PFA*Self-control } & & -0.019 & & -0.296 \\
\hline & & $(0.209)$ & & $(0.192)$ \\
\hline \multirow[t]{2}{*}{ Non-prof advice $(=1)$} & 0.132 & 0.132 & $0.168^{* *}$ & $0.172 * *$ \\
\hline & $(0.093)$ & $(0.093)$ & $(0.085)$ & $(0.085)$ \\
\hline \multirow[t]{2}{*}{ Log(total monthly income) } & -0.024 & -0.024 & 0.094 & 0.091 \\
\hline & $(0.075)$ & $(0.075)$ & $(0.070)$ & $(0.070)$ \\
\hline \multirow[t]{2}{*}{ Log(annual windfall income) } & $0.019^{*}$ & $0.019 *$ & $0.021^{* *}$ & $0.021 * *$ \\
\hline & $(0.011)$ & $(0.011)$ & $(0.010)$ & $(0.010)$ \\
\hline \multirow[t]{2}{*}{ Age } & 0.020 & 0.020 & $0.279 * *$ & $0.276^{* *}$ \\
\hline & $(0.131)$ & $(0.131)$ & $(0.119)$ & $(0.119)$ \\
\hline \multirow[t]{2}{*}{ Age-square } & $-0.244 * * *$ & $-0.244 * * *$ & $-0.260 * * *$ & $-0.260 * * *$ \\
\hline & $(0.077)$ & $(0.077)$ & $(0.071)$ & $(0.071)$ \\
\hline \multirow{2}{*}{ Own finance expectation } & $0.087 * * *$ & $0.087 * * *$ & $-0.047 * *$ & $-0.047 * *$ \\
\hline & $(0.023)$ & $(0.023)$ & $(0.021)$ & $(0.021)$ \\
\hline \multirow[t]{2}{*}{ Family Size } & $0.177^{* *}$ & $0.177 * *$ & 0.107 & 0.106 \\
\hline & $(0.071)$ & $(0.071)$ & $(0.065)$ & $(0.065)$ \\
\hline \multirow{2}{*}{ Married (=1) } & $-0.508^{*}$ & $-0.508^{*}$ & $0.630^{* *}$ & $0.624 * *$ \\
\hline & $(0.299)$ & $(0.299)$ & $(0.272)$ & $(0.272)$ \\
\hline \multirow[t]{2}{*}{ Separated $(=1)$} & $-1.110 * * *$ & $-1.110 * * *$ & $0.846^{* *}$ & $0.842 * *$ \\
\hline & $(0.403)$ & $(0.403)$ & $(0.369)$ & $(0.368)$ \\
\hline \multirow[t]{2}{*}{ Divorced $(=1)$} & $-0.897 * *$ & $-0.897 * *$ & $0.748 * *$ & $0.747 * *$ \\
\hline & $(0.403)$ & $(0.403)$ & $(0.368)$ & $(0.367)$ \\
\hline \multirow[t]{2}{*}{ Widowed (=1) } & $-0.919 *$ & $-0.919^{*}$ & $0.807 *$ & $0.793 *$ \\
\hline & $(0.513)$ & $(0.513)$ & $(0.471)$ & $(0.471)$ \\
\hline \multirow{2}{*}{ Part-time employed $(=1)$} & 0.266 & 0.266 & -0.211 & -0.214 \\
\hline & $(0.196)$ & $(0.196)$ & $(0.179)$ & $(0.179)$ \\
\hline \multirow[t]{2}{*}{ Unemployed $(=1)$} & 0.233 & 0.233 & $-0.393 * *$ & $-0.399 * *$ \\
\hline & $(0.199)$ & $(0.199)$ & $(0.181)$ & $(0.181)$ \\
\hline \multirow[t]{2}{*}{ Retired $(=1)$} & 0.171 & 0.171 & 0.007 & 0.004 \\
\hline & $(0.245)$ & $(0.245)$ & $(0.226)$ & $(0.226)$ \\
\hline \multirow[t]{2}{*}{ Save for emergency } & 0.006 & 0.006 & 0.021 & 0.020 \\
\hline & $(0.016)$ & $(0.016)$ & $(0.015)$ & $(0.015)$ \\
\hline \multirow[t]{2}{*}{ Save for old-age provision } & 0.011 & 0.011 & $-0.027^{*}$ & $-0.028^{*}$ \\
\hline & $(0.015)$ & $(0.015)$ & $(0.014)$ & $(0.014)$ \\
\hline Save for children education & $0.054 * * *$ & $0.054 * * *$ & -0.018 & -0.018 \\
\hline & $(0.017)$ & $(0.017)$ & $(0.016)$ & $(0.016)$ \\
\hline Save for bequests & -0.002 & -0.002 & $0.102 * * *$ & $0.102 * * *$ \\
\hline & $(0.012)$ & $(0.012)$ & $(0.011)$ & $(0.011)$ \\
\hline Constant & $11.292 * *$ & $11.295^{* *}$ & -4.350 & -4.175 \\
\hline & $(5.642)$ & $(5.644)$ & $(5.127)$ & (5.128) \\
\hline Time dummies & Yes & Yes & Yes & Yes \\
\hline $\mathrm{N}$ of observations & 12,390 & 12,390 & 12,075 & 12,075 \\
\hline $\mathrm{N}$ of households & 3,891 & 3,891 & 3,857 & 3,857 \\
\hline
\end{tabular}

Note: $* * *$ denotes coefficients significant at $1 \%$ level, $* *$ denotes coefficients significant at $5 \%$ level, and $*$ denotes coefficients significant at $10 \%$ level. 
Table 5.22: Fixed-effects regressions by using lagged independent variables

\begin{tabular}{|c|c|c|c|c|}
\hline \multirow{2}{*}{ Dependent variables: } & \multicolumn{2}{|c|}{$\begin{array}{l}\log (\text { Savings out of } \\
\text { windfall at } t)\end{array}$} & \multicolumn{2}{|c|}{$\log ($ Annual savings at $t)$} \\
\hline & (1) & (2) & (1) & (2) \\
\hline \multirow[t]{2}{*}{ PFA $(=1)$ at $\mathrm{t}-1$} & -0.006 & 0.012 & 0.049 & 0.058 \\
\hline & $(0.077)$ & $(0.078)$ & $(0.087)$ & $(0.088)$ \\
\hline \multirow[t]{2}{*}{ Self-control at $\mathrm{t}-1$} & -0.194 & -0.106 & -0.046 & 0.003 \\
\hline & $(0.135)$ & $(0.147)$ & $(0.150)$ & $(0.164)$ \\
\hline \multirow[t]{2}{*}{ PFA(t-1)*Self-control(t-1) } & & -0.277 & & -0.150 \\
\hline & & $(0.179)$ & & $(0.202)$ \\
\hline \multirow[t]{2}{*}{ Non-prof advice $(=1)$ at $\mathrm{t}-1$} & -0.104 & -0.102 & 0.088 & 0.089 \\
\hline & $(0.078)$ & $(0.078)$ & $(0.089)$ & $(0.089)$ \\
\hline \multirow[t]{2}{*}{$\log ($ total monthly income at $\mathrm{t})$} & 0.036 & 0.037 & $0.423 * * *$ & $0.423 * * *$ \\
\hline & $(0.068)$ & $(0.068)$ & $(0.081)$ & $(0.081)$ \\
\hline \multirow[t]{2}{*}{$\log ($ annual windfall income at $t)$} & $0.477 * * *$ & $0.477 * * *$ & $0.049 * * *$ & $0.049 * * *$ \\
\hline & $(0.009)$ & $(0.009)$ & $(0.010)$ & $(0.010)$ \\
\hline \multirow{2}{*}{ Age at $t-1$} & -0.062 & -0.065 & 0.020 & 0.020 \\
\hline & $(0.116)$ & $(0.116)$ & $(0.129)$ & $(0.129)$ \\
\hline \multirow[t]{2}{*}{ Age-square at $\mathrm{t}-1$} & 0.108 & 0.108 & -0.042 & -0.043 \\
\hline & $(0.082)$ & $(0.082)$ & $(0.076)$ & $(0.076)$ \\
\hline \multirow[t]{2}{*}{ Own finance expectation at $t-1$} & -0.001 & -0.001 & 0.032 & 0.032 \\
\hline & $(0.020)$ & $(0.020)$ & $(0.023)$ & $(0.023)$ \\
\hline \multirow[t]{2}{*}{ Family Size at t-1 } & 0.017 & 0.017 & -0.085 & -0.085 \\
\hline & $(0.065)$ & $(0.065)$ & $(0.071)$ & $(0.071)$ \\
\hline \multirow{2}{*}{ Married (=1) at $\mathrm{t}-1$} & -0.120 & -0.121 & 0.467 & 0.464 \\
\hline & $(0.261)$ & $(0.261)$ & $(0.295)$ & $(0.295)$ \\
\hline \multirow[t]{2}{*}{ Separated $(=1)$ at $\mathrm{t}-1$} & -0.039 & -0.035 & -0.444 & -0.446 \\
\hline & $(0.360)$ & $(0.360)$ & $(0.397)$ & $(0.397)$ \\
\hline \multirow[t]{2}{*}{ Divorced $(=1)$ at $\mathrm{t}-1$} & -0.058 & -0.056 & -0.029 & -0.028 \\
\hline & $(0.364)$ & $(0.364)$ & $(0.398)$ & $(0.398)$ \\
\hline \multirow[t]{2}{*}{ Widowed $(=1)$ at $\mathrm{t}-1$} & -0.558 & -0.573 & -0.630 & -0.636 \\
\hline & $(0.445)$ & $(0.445)$ & $(0.494)$ & $(0.494)$ \\
\hline \multirow{2}{*}{ Part-time employed $(=1)$ at $\mathrm{t}-1$} & -0.112 & -0.117 & -0.213 & -0.215 \\
\hline & $(0.179)$ & $(0.179)$ & $(0.195)$ & $(0.195)$ \\
\hline \multirow[t]{2}{*}{ Unemployed ( $=1)$ at $\mathrm{t}-1$} & -0.002 & -0.009 & -0.283 & -0.286 \\
\hline & $(0.182)$ & $(0.182)$ & $(0.198)$ & $(0.198)$ \\
\hline \multirow[t]{2}{*}{ Retired $(=1)$ at $\mathrm{t}-1$} & 0.129 & 0.123 & -0.277 & -0.279 \\
\hline & $(0.229)$ & $(0.229)$ & $(0.239)$ & $(0.239)$ \\
\hline \multirow[t]{2}{*}{ Save for emergency at $\mathrm{t}-1$} & 0.009 & 0.008 & 0.009 & 0.009 \\
\hline & $(0.013)$ & $(0.013)$ & $(0.015)$ & $(0.015)$ \\
\hline \multirow[t]{2}{*}{ Save for old-age provision at $\mathrm{t}-1$} & 0.013 & 0.013 & 0.004 & 0.004 \\
\hline & $(0.013)$ & $(0.013)$ & $(0.015)$ & $(0.015)$ \\
\hline Save for children education at $\mathrm{t}-1$ & -0.022 & -0.022 & -0.009 & -0.009 \\
\hline & $(0.015)$ & $(0.015)$ & $(0.017)$ & $(0.017)$ \\
\hline Save for bequests at $\mathrm{t}-1$ & -0.000 & -0.000 & -0.007 & -0.007 \\
\hline & $(0.010)$ & $(0.010)$ & $(0.011)$ & $(0.011)$ \\
\hline Constant & 0.093 & 0.250 & 1.180 & 1.241 \\
\hline & $(4.557)$ & (4.558) & $(5.583)$ & (5.584) \\
\hline Time dummies & Yes & Yes & Yes & Yes \\
\hline $\mathrm{N}$ of observations & 8,584 & 8,584 & 9,700 & 9,700 \\
\hline $\mathrm{N}$ of households & 3,033 & 3,033 & 2,950 & 2,950 \\
\hline
\end{tabular}

Note: $* * *$ denotes coefficients significant at $1 \%$ level, $* *$ denotes coefficients significant at $5 \%$ level, and $*$ denotes coefficients significant at $10 \%$ level. 
Table 5.23: Fixed-effects regressions by using lagged independent variables

\begin{tabular}{|c|c|c|c|c|}
\hline \multirow[t]{2}{*}{ Dependent variables: } & \multicolumn{2}{|c|}{$\begin{array}{l}\log (\mathrm{O} w n \text { pension } \\
\text { contribution at } \mathrm{t})\end{array}$} & \multicolumn{2}{|c|}{$\begin{array}{c}\text { Log(Emergency funds } \\
\text { at } \mathrm{t}-1)\end{array}$} \\
\hline & $(1)$ & $(2)$ & $(1)$ & $(2)$ \\
\hline \multirow[t]{2}{*}{ PFA $(=1)$ at $t-1$} & 0.015 & 0.025 & $0.183 * *$ & $0.208 * * *$ \\
\hline & $(0.047)$ & $(0.048)$ & $(0.078)$ & $(0.079)$ \\
\hline \multirow[t]{2}{*}{ Self-control at t-1 } & $-0.145^{*}$ & -0.090 & $0.568 * * *$ & $0.689 * * *$ \\
\hline & $(0.082)$ & $(0.090)$ & $(0.138)$ & $(0.151)$ \\
\hline \multirow[t]{2}{*}{ PFA(t-1)*Self-control(t-1) } & & -0.166 & & $-0.358 *$ \\
\hline & & $(0.110)$ & & $(0.183)$ \\
\hline \multirow[t]{2}{*}{ Non-prof advice $(=1)$ at $t-1$} & 0.033 & 0.034 & 0.106 & 0.109 \\
\hline & $(0.048)$ & $(0.048)$ & $(0.080)$ & $(0.080)$ \\
\hline \multirow[t]{2}{*}{$\log ($ total monthly income at $\mathrm{t})$} & $0.091 * *$ & $0.090 * *$ & -0.030 & -0.031 \\
\hline & $(0.045)$ & $(0.045)$ & $(0.079)$ & $(0.079)$ \\
\hline \multirow[t]{2}{*}{$\log ($ annual windfall income at $t)$} & $0.013 * *$ & $0.013 * *$ & -0.012 & -0.013 \\
\hline & $(0.006)$ & $(0.006)$ & $(0.009)$ & $(0.009)$ \\
\hline \multirow[t]{2}{*}{ Age at $t-1$} & $-0.296 * * *$ & $-0.297 * * *$ & -0.020 & -0.024 \\
\hline & $(0.071)$ & $(0.071)$ & $(0.120)$ & $(0.120)$ \\
\hline \multirow[t]{2}{*}{ Age-square at t-1 } & -0.040 & -0.040 & $0.572 * * *$ & $0.571 * * *$ \\
\hline & $(0.042)$ & $(0.042)$ & $(0.070)$ & $(0.070)$ \\
\hline \multirow[t]{2}{*}{ Own finance expectation at $t-1$} & -0.001 & -0.001 & 0.024 & 0.024 \\
\hline & $(0.012)$ & $(0.012)$ & $(0.021)$ & $(0.021)$ \\
\hline \multirow[t]{2}{*}{ Family Size at t-1 } & 0.007 & 0.006 & $0.204 * * *$ & $0.203 * * *$ \\
\hline & $(0.039)$ & $(0.039)$ & $(0.065)$ & $(0.065)$ \\
\hline \multirow[t]{2}{*}{ Married $(=1)$ at $\mathrm{t}-1$} & 0.172 & 0.170 & 0.169 & 0.167 \\
\hline & $(0.158)$ & $(0.158)$ & $(0.267)$ & $(0.267)$ \\
\hline \multirow[t]{2}{*}{ Separated $(=1)$ at $\mathrm{t}-1$} & 0.188 & 0.189 & 0.019 & 0.021 \\
\hline & $(0.217)$ & $(0.217)$ & $(0.365)$ & $(0.365)$ \\
\hline \multirow[t]{2}{*}{ Divorced $(=1)$ at $t-1$} & 0.167 & 0.169 & -0.325 & -0.317 \\
\hline & $(0.214)$ & $(0.214)$ & $(0.358)$ & $(0.358)$ \\
\hline \multirow[t]{2}{*}{ Widowed $(=1)$ at $\mathrm{t}-1$} & 0.274 & 0.268 & 0.383 & 0.369 \\
\hline & $(0.279)$ & $(0.279)$ & $(0.448)$ & $(0.448)$ \\
\hline \multirow[t]{2}{*}{ Part-time employed $(=1)$ at $\mathrm{t}-1$} & -0.073 & -0.076 & 0.039 & 0.037 \\
\hline & $(0.103)$ & $(0.103)$ & $(0.178)$ & $(0.178)$ \\
\hline \multirow[t]{2}{*}{ Unemployed $(=1)$ at $\mathrm{t}-1$} & -0.015 & -0.019 & 0.109 & 0.101 \\
\hline & $(0.107)$ & $(0.107)$ & $(0.182)$ & $(0.182)$ \\
\hline \multirow[t]{2}{*}{ Retired $(=1)$ at $t-1$} & $-0.273 * *$ & $-0.277 * *$ & $0.449 * *$ & $0.442 * *$ \\
\hline & $(0.129)$ & $(0.129)$ & $(0.214)$ & $(0.214)$ \\
\hline \multirow[t]{2}{*}{ Save for emergency at $\mathrm{t}-1$} & 0.008 & 0.008 & $0.033 * *$ & $0.033 * *$ \\
\hline & $(0.008)$ & $(0.008)$ & $(0.014)$ & $(0.014)$ \\
\hline \multirow[t]{2}{*}{ Save for old-age provision at $\mathrm{t}-1$} & -0.002 & -0.002 & 0.008 & 0.008 \\
\hline & $(0.008)$ & $(0.008)$ & $(0.014)$ & $(0.014)$ \\
\hline Save for children education at $\mathrm{t}-1$ & -0.000 & -0.001 & $0.104 * * *$ & $0.103 * * *$ \\
\hline & $(0.009)$ & $(0.009)$ & $(0.016)$ & $(0.016)$ \\
\hline Save for bequests at $t-1$ & -0.010 & -0.010 & $-0.022 * *$ & $-0.022 * *$ \\
\hline & $(0.006)$ & $(0.006)$ & $(0.010)$ & $(0.010)$ \\
\hline Constant & $16.393 * * *$ & $16.499 * * *$ & $-9.138 *$ & $-8.884 *$ \\
\hline & $(3.070)$ & $(3.071)$ & $(5.215)$ & $(5.215)$ \\
\hline Time dummies & Yes & Yes & Yes & Yes \\
\hline $\mathrm{N}$ of observations & 9,452 & 9,452 & 8,805 & 8,805 \\
\hline $\mathrm{N}$ of households & 2,937 & 2,937 & 2,841 & 2,841 \\
\hline
\end{tabular}


Table 5.24: Fixed-effects regressions by using lagged independent variables

\begin{tabular}{|c|c|c|c|c|}
\hline \multirow{2}{*}{ Dependent variables: } & \multicolumn{2}{|c|}{$\overline{\log (\text { Financial assets at } \mathrm{t})}$} & \multicolumn{2}{|c|}{ Log(Illiquid assets at $\mathrm{t})$} \\
\hline & (1) & (2) & (1) & (2) \\
\hline \multirow[t]{2}{*}{ PFA $(=1)$ at $\mathrm{t}-1$} & $0.168^{*}$ & $0.192 * *$ & 0.086 & 0.093 \\
\hline & $(0.089)$ & $(0.090)$ & $(0.091)$ & $(0.092)$ \\
\hline \multirow[t]{2}{*}{ Self-control at t-1 } & 0.222 & $0.340 * *$ & $-0.314 * *$ & -0.282 \\
\hline & $(0.156)$ & $(0.171)$ & $(0.158)$ & $(0.173)$ \\
\hline \multirow[t]{2}{*}{ PFA(t-1)*Self-control(t-1) } & & $-0.355^{*}$ & & -0.098 \\
\hline & & $(0.208)$ & & $(0.212)$ \\
\hline \multirow[t]{2}{*}{ Non-prof advice $(=1)$ at $\mathrm{t}-1$} & -0.025 & -0.023 & -0.050 & -0.050 \\
\hline & $(0.091)$ & $(0.091)$ & $(0.092)$ & $(0.092)$ \\
\hline \multirow[t]{2}{*}{$\log ($ total monthly income at $\mathrm{t})$} & 0.123 & 0.122 & $0.178^{* *}$ & $0.178 * *$ \\
\hline & $(0.086)$ & $(0.086)$ & $(0.082)$ & $(0.082)$ \\
\hline \multirow[t]{2}{*}{$\log ($ annual windfall income at $t)$} & $0.034 * * *$ & $0.034 * * *$ & -0.008 & -0.008 \\
\hline & $(0.011)$ & $(0.011)$ & $(0.011)$ & $(0.011)$ \\
\hline \multirow[t]{2}{*}{ Age at $t-1$} & $1.257 * * *$ & $1.253 * * *$ & $4.970 * * *$ & $4.969 * * *$ \\
\hline & $(0.135)$ & $(0.135)$ & $(0.136)$ & $(0.136)$ \\
\hline \multirow[t]{2}{*}{ Age-square at $\mathrm{t}-1$} & -0.069 & -0.069 & $0.210 * * *$ & $0.210 * * *$ \\
\hline & $(0.079)$ & $(0.078)$ & $(0.080)$ & $(0.080)$ \\
\hline \multirow{2}{*}{ Own finance expectation at $t-1$} & $0.043 *$ & $0.043^{*}$ & -0.027 & -0.027 \\
\hline & $(0.023)$ & $(0.023)$ & $(0.024)$ & $(0.024)$ \\
\hline \multirow[t]{2}{*}{ Family Size at $\mathrm{t}-1$} & 0.095 & 0.094 & $0.149 * *$ & $0.148 * *$ \\
\hline & $(0.074)$ & $(0.074)$ & $(0.075)$ & $(0.075)$ \\
\hline \multirow{2}{*}{ Married $(=1)$ at $\mathrm{t}-1$} & 0.116 & 0.111 & 0.408 & 0.407 \\
\hline & $(0.300)$ & $(0.300)$ & $(0.306)$ & $(0.306)$ \\
\hline \multirow[t]{2}{*}{ Separated $(=1)$ at $\mathrm{t}-1$} & 0.288 & 0.287 & 0.295 & 0.295 \\
\hline & $(0.410)$ & $(0.410)$ & $(0.417)$ & $(0.417)$ \\
\hline \multirow{2}{*}{ Divorced $(=1)$ at $\mathrm{t}-1$} & -0.375 & -0.372 & 0.046 & 0.047 \\
\hline & $(0.406)$ & $(0.406)$ & $(0.415)$ & $(0.415)$ \\
\hline \multirow[t]{2}{*}{ Widowed $(=1)$ at $\mathrm{t}-1$} & -0.404 & -0.419 & 0.272 & 0.268 \\
\hline & $(0.499)$ & $(0.500)$ & $(0.511)$ & $(0.511)$ \\
\hline \multirow[t]{2}{*}{ Part-time employed $(=1)$ at $t-1$} & -0.109 & -0.116 & -0.094 & -0.095 \\
\hline & $(0.200)$ & $(0.200)$ & $(0.205)$ & $(0.205)$ \\
\hline \multirow[t]{2}{*}{ Unemployed $(=1)$ at $\mathrm{t}-1$} & -0.146 & -0.154 & -0.114 & -0.116 \\
\hline & $(0.206)$ & $(0.206)$ & $(0.209)$ & $(0.209)$ \\
\hline \multirow[t]{2}{*}{ Retired $(=1)$ at $\mathrm{t}-1$} & $-0.410^{*}$ & $-0.419^{*}$ & 0.166 & 0.165 \\
\hline & $(0.247)$ & $(0.247)$ & $(0.250)$ & $(0.250)$ \\
\hline \multirow[t]{2}{*}{ Save for emergency at $t-1$} & -0.024 & -0.025 & -0.007 & -0.007 \\
\hline & $(0.016)$ & $(0.016)$ & $(0.016)$ & $(0.016)$ \\
\hline \multirow[t]{2}{*}{ Save for vacation at $\mathrm{t}-1$} & 0.018 & 0.018 & -0.010 & -0.010 \\
\hline & $(0.013)$ & $(0.013)$ & $(0.014)$ & $(0.014)$ \\
\hline Save for children education at $\mathrm{t}-1$ & -0.016 & -0.017 & -0.007 & -0.007 \\
\hline & $(0.017)$ & $(0.017)$ & $(0.017)$ & $(0.017)$ \\
\hline Save for bequests at $\mathrm{t}-1$ & -0.010 & -0.010 & -0.003 & -0.003 \\
\hline & $(0.011)$ & $(0.011)$ & $(0.012)$ & $(0.012)$ \\
\hline Constant & $-57.173 * * *$ & $-56.937 * * *$ & $-257.409 * * *$ & $-257.357 * * *$ \\
\hline & $(5.850)$ & $(5.851)$ & $\begin{array}{c}(5.905) \\
\text { Yes }\end{array}$ & $\begin{array}{c}(5.906) \\
\text { Yes }\end{array}$ \\
\hline Time dummies & Yes & Yes & Yes & Yes \\
\hline $\mathrm{N}$ of observations & 10,083 & 10,083 & 10,522 & 10,522 \\
\hline $\mathrm{N}$ of households & 2,977 & 2,977 & 3,037 & 3,037 \\
\hline
\end{tabular}

Note: $* * *$ denotes coefficients significant at $1 \%$ level, $* *$ denotes coefficients significant at $5 \%$ level, and * denotes coefficients significant at $10 \%$ level. 
Table 5.25: Fixed-effects regressions by using lagged independent variables

\begin{tabular}{|c|c|c|c|c|}
\hline \multirow{2}{*}{ Dependent variables: } & \multicolumn{2}{|c|}{ Log(Total assets at $\mathrm{t})$} & \multicolumn{2}{|c|}{$\bar{L} \log ($ Total Loan at $\mathrm{t})$} \\
\hline & (1) & (2) & (1) & (2) \\
\hline \multirow[t]{2}{*}{ PFA $(=1)$ at $t-1$} & 0.091 & 0.084 & -0.085 & -0.080 \\
\hline & $(0.079)$ & $(0.080)$ & $(0.087)$ & $(0.088)$ \\
\hline \multirow[t]{2}{*}{ Self-control at $\mathrm{t}-1$} & 0.071 & 0.035 & -0.189 & -0.163 \\
\hline & $(0.137)$ & $(0.149)$ & $(0.151)$ & $(0.165)$ \\
\hline \multirow[t]{2}{*}{ PFA(t-1)*Self-control(t-1) } & & 0.108 & & -0.080 \\
\hline & & $(0.183)$ & & $(0.202)$ \\
\hline \multirow{2}{*}{ Non-prof advice $(=1)$ at $\mathrm{t}-1$} & $-0.146^{*}$ & $-0.146^{*}$ & 0.008 & 0.009 \\
\hline & $(0.080)$ & $(0.080)$ & $(0.088)$ & $(0.088)$ \\
\hline \multirow[t]{2}{*}{$\log ($ total monthly income at $\mathrm{t})$} & $0.169^{* *}$ & $0.169^{* *}$ & $0.141^{*}$ & $0.141^{*}$ \\
\hline & $(0.071)$ & $(0.071)$ & $(0.082)$ & $(0.082)$ \\
\hline \multirow[t]{2}{*}{$\log ($ annual windfall income at $t)$} & 0.005 & 0.005 & $0.024 * *$ & $0.024 * *$ \\
\hline & $(0.009)$ & $(0.009)$ & $(0.010)$ & $(0.010)$ \\
\hline \multirow[t]{2}{*}{ Age at $t-1$} & $3.312^{* * *}$ & $3.313 * * *$ & $0.294 * *$ & $0.293 * *$ \\
\hline & $(0.117)$ & $(0.117)$ & $(0.129)$ & $(0.129)$ \\
\hline \multirow[t]{2}{*}{ Age-square at $\mathrm{t}-1$} & -0.027 & -0.027 & $-0.381 * * *$ & $-0.381 * * *$ \\
\hline & $(0.069)$ & $(0.069)$ & $(0.076)$ & $(0.076)$ \\
\hline \multirow[t]{2}{*}{ Own finance expectation at $t-1$} & 0.021 & 0.021 & -0.018 & -0.018 \\
\hline & $(0.020)$ & $(0.020)$ & $(0.023)$ & $(0.023)$ \\
\hline \multirow[t]{2}{*}{ Family Size at $\mathrm{t}-1$} & 0.036 & 0.036 & 0.116 & 0.116 \\
\hline & $(0.065)$ & $(0.065)$ & $(0.071)$ & $(0.071)$ \\
\hline \multirow{2}{*}{ Married $(=1)$ at $\mathrm{t}-1$} & $0.582 * *$ & $0.584 * *$ & $0.644 * *$ & $0.642 * *$ \\
\hline & $(0.265)$ & $(0.265)$ & $(0.290)$ & $(0.290)$ \\
\hline \multirow[t]{2}{*}{ Separated $(=1)$ at $\mathrm{t}-1$} & $0.653^{*}$ & $0.653^{*}$ & 0.517 & 0.516 \\
\hline & $(0.360)$ & $(0.360)$ & $(0.397)$ & $(0.397)$ \\
\hline \multirow{2}{*}{ Divorced $(=1)$ at $\mathrm{t}-1$} & 0.160 & 0.159 & 0.233 & 0.234 \\
\hline & $(0.359)$ & $(0.359)$ & $(0.394)$ & $(0.394)$ \\
\hline \multirow[t]{2}{*}{ Widowed $(=1)$ at $\mathrm{t}-1$} & -0.195 & -0.191 & 0.564 & 0.560 \\
\hline & $(0.440)$ & $(0.440)$ & $(0.489)$ & $(0.489)$ \\
\hline \multirow[t]{2}{*}{ Part-time employed $(=1)$ at $t-1$} & 0.083 & 0.084 & -0.224 & -0.225 \\
\hline & $(0.177)$ & $(0.177)$ & $(0.194)$ & $(0.194)$ \\
\hline \multirow[t]{2}{*}{ Unemployed $(=1)$ at $\mathrm{t}-1$} & -0.068 & -0.065 & $-0.430 * *$ & $-0.432 * *$ \\
\hline & $(0.181)$ & $(0.181)$ & $(0.199)$ & $(0.199)$ \\
\hline \multirow[t]{2}{*}{ Retired $(=1)$ at $\mathrm{t}-1$} & 0.069 & 0.071 & $-0.525 * *$ & $-0.527 * *$ \\
\hline & $(0.216)$ & $(0.216)$ & $(0.239)$ & $(0.239)$ \\
\hline \multirow[t]{2}{*}{ Save for emergency at $t-1$} & -0.013 & -0.013 & 0.018 & 0.018 \\
\hline & $(0.014)$ & $(0.014)$ & $(0.015)$ & $(0.015)$ \\
\hline \multirow[t]{2}{*}{ Save for vacation at $\mathrm{t}-1$} & 0.004 & 0.004 & 0.008 & 0.008 \\
\hline & $(0.012)$ & $(0.012)$ & $(0.013)$ & $(0.013)$ \\
\hline Save for children education at $\mathrm{t}-1$ & -0.012 & -0.011 & -0.004 & -0.004 \\
\hline & $(0.015)$ & $(0.015)$ & $(0.017)$ & $(0.017)$ \\
\hline Save for bequests at $\mathrm{t}-1$ & -0.009 & -0.009 & $0.042 * * *$ & $0.042 * * *$ \\
\hline & $(0.010)$ & $(0.010)$ & $(0.011)$ & $(0.011)$ \\
\hline Constant & $-163.038^{* * *}$ & $-163.093^{* * *}$ & -1.847 & -1.794 \\
\hline & $(5.102)$ & $(5.103)$ & $(5.562)$ & $(5.564)$ \\
\hline Time dummies & Yes & Yes & Yes & Yes \\
\hline $\mathrm{N}$ of observations & 10,532 & 10,532 & 10,146 & 10,146 \\
\hline $\mathrm{N}$ of households & 3,037 & 3,037 & 2,997 & 2,997 \\
\hline
\end{tabular}

Note: $* * *$ denotes coefficients significant at $1 \%$ level, $* *$ denotes coefficients significant at $5 \%$ level, and * denotes coefficients significant at $10 \%$ level. 
Table 5.26: OLS regressions by using lagged independent variables

\begin{tabular}{|c|c|c|c|c|}
\hline \multirow[t]{2}{*}{ Dependent variables: } & \multicolumn{2}{|c|}{$\begin{array}{l}\log (\text { Savings out of } \\
\text { windfall at } t)\end{array}$} & \multicolumn{2}{|c|}{$\begin{array}{c}\log (\text { Annual savings } \\
\text { at } t)\end{array}$} \\
\hline & $(1)$ & (2) & (1) & (2) \\
\hline \multirow[t]{2}{*}{ PFA $(=1)$ at $t-1$} & $0.126^{* *}$ & $0.141 * *$ & $0.430 * * *$ & $0.440 * * *$ \\
\hline & $(0.060)$ & $(0.060)$ & $(0.087)$ & $(0.089)$ \\
\hline \multirow[t]{2}{*}{ Self-control at $\mathrm{t}-1$} & -0.057 & 0.017 & $2.339 * * *$ & $2.388 * * *$ \\
\hline & $(0.069)$ & $(0.073)$ & $(0.113)$ & $(0.126)$ \\
\hline \multirow[t]{2}{*}{ PFA(t-1)*Self-control(t-1) } & & -0.231 & & -0.154 \\
\hline & & $(0.143)$ & & $(0.191)$ \\
\hline \multirow[t]{2}{*}{ Non-prof advice $(=1)$ at t-1 } & 0.019 & 0.021 & -0.064 & -0.063 \\
\hline & $(0.056)$ & $(0.056)$ & $(0.088)$ & $(0.088)$ \\
\hline \multirow[t]{2}{*}{$\log ($ total monthly income at $\mathrm{t})$} & 0.050 & 0.049 & $0.973 * * *$ & $0.973 * * *$ \\
\hline & $(0.037)$ & $(0.037)$ & $(0.090)$ & $(0.090)$ \\
\hline \multirow[t]{2}{*}{$\log ($ annual windfall income at $t)$} & $0.485 * * *$ & $0.485 * * *$ & $0.109 * * *$ & $0.109 * * *$ \\
\hline & $(0.012)$ & $(0.012)$ & $(0.011)$ & $(0.011)$ \\
\hline \multirow[t]{2}{*}{ Age at $t-1$} & 0.014 & 0.014 & -0.020 & -0.020 \\
\hline & $(0.011)$ & $(0.011)$ & $(0.021)$ & $(0.021)$ \\
\hline \multirow[t]{2}{*}{ Age-square at t-1 } & -0.014 & -0.014 & 0.011 & 0.011 \\
\hline & $(0.011)$ & $(0.011)$ & $(0.021)$ & $(0.021)$ \\
\hline \multirow[t]{2}{*}{ Own finance expectation at $\mathrm{t}-1$} & 0.005 & 0.005 & $0.211 * * *$ & $0.211 * * *$ \\
\hline & $(0.012)$ & $(0.012)$ & $(0.020)$ & $(0.020)$ \\
\hline \multirow[t]{2}{*}{ Family Size at t-1 } & 0.023 & 0.022 & $-0.198 * * *$ & $-0.198 * * *$ \\
\hline & $(0.026)$ & $(0.026)$ & $(0.047)$ & $(0.047)$ \\
\hline \multirow[t]{2}{*}{ Married (=1) at t-1 } & -0.127 & -0.126 & 0.149 & 0.150 \\
\hline & $(0.088)$ & $(0.088)$ & $(0.161)$ & $(0.161)$ \\
\hline \multirow[t]{2}{*}{ Separated $(=1)$ at $\mathrm{t}-1$} & 0.188 & 0.196 & $-0.763 * *$ & $-0.760 * *$ \\
\hline & $(0.174)$ & $(0.174)$ & $(0.302)$ & $(0.302)$ \\
\hline \multirow[t]{2}{*}{ Divorced $(=1)$ at $\mathrm{t}-1$} & -0.001 & 0.002 & -0.261 & -0.259 \\
\hline & $(0.099)$ & $(0.099)$ & $(0.191)$ & $(0.191)$ \\
\hline \multirow[t]{2}{*}{ Widowed $(=1)$ at $\mathrm{t}-1$} & -0.089 & -0.091 & $-0.579 * *$ & $-0.580 * *$ \\
\hline & $(0.110)$ & $(0.110)$ & $(0.239)$ & $(0.239)$ \\
\hline \multirow[t]{2}{*}{ Part-time employed $(=1)$ at t-1 } & -0.069 & -0.065 & $-0.269 *$ & $-0.267^{*}$ \\
\hline & $(0.091)$ & $(0.091)$ & $(0.149)$ & $(0.149)$ \\
\hline \multirow[t]{2}{*}{ Unemployed $(=1)$ at $t-1$} & $0.144 *$ & $0.147^{*}$ & $-0.681 * * *$ & $-0.679 * * *$ \\
\hline & $(0.086)$ & $(0.086)$ & $(0.147)$ & $(0.147)$ \\
\hline \multirow[t]{2}{*}{ Retired $(=1)$ at $\mathrm{t}-1$} & 0.019 & 0.021 & -0.243 & -0.241 \\
\hline & $(0.104)$ & $(0.104)$ & $(0.164)$ & $(0.164)$ \\
\hline \multirow[t]{2}{*}{ Save for emergency at t-1 } & -0.014 & -0.015 & $0.070 * * *$ & $0.069 * * *$ \\
\hline & $(0.009)$ & $(0.009)$ & $(0.015)$ & $(0.015)$ \\
\hline \multirow[t]{2}{*}{ Save for old-age provision at $\mathrm{t}-1$} & 0.005 & 0.006 & 0.019 & 0.019 \\
\hline & $(0.009)$ & $(0.009)$ & $(0.015)$ & $(0.015)$ \\
\hline Save for children education at $\mathrm{t}-1$ & -0.014 & -0.014 & $0.125 * * *$ & $0.125 * * *$ \\
\hline & $(0.010)$ & $(0.010)$ & $(0.017)$ & $(0.017)$ \\
\hline Save for bequests at $t-1$ & $0.024 * * *$ & $0.024 * * *$ & $-0.089 * * *$ & $-0.089 * * *$ \\
\hline & $(0.007)$ & $(0.007)$ & $(0.011)$ & $(0.011)$ \\
\hline Constant & $-0.951 * *$ & $-0.940 * *$ & $-4.398 * * *$ & $-4.388 * * *$ \\
\hline & $(0.437)$ & $(0.437)$ & $(0.872)$ & $(0.872)$ \\
\hline Time dummies & Yes & Yes & Yes & Yes \\
\hline $\mathrm{N}$ of observations & 8,584 & 8,584 & 9,700 & 9,700 \\
\hline R-square & 0.424 & 0.424 & 0.268 & 0.268 \\
\hline
\end{tabular}

Note: The regressions control for head gender, head's education (no high school, high school, university), German nationality, residence states, and saving for vacation. The variations in sample sizes among different regressions are due to the missing values in the dependent variables. $* * *$ denotes coefficients significant at $1 \%$ level, $* *$ denotes coefficients significant at 5\% level, and * denotes coefficients significant at $10 \%$ level. 
Table 5.27: OLS regressions by using lagged independent variables

\begin{tabular}{|c|c|c|c|c|}
\hline \multirow[t]{2}{*}{ Dependent variables: } & \multicolumn{2}{|c|}{$\begin{array}{l}\text { Log }(\text { Own pension } \\
\text { contribution at } t)\end{array}$} & \multicolumn{2}{|c|}{$\begin{array}{c}\log (\text { Emergency funds } \\
\text { at } \mathrm{t}-1)\end{array}$} \\
\hline & (1) & (2) & (1) & (2) \\
\hline PFA $(=1)$ at $\mathrm{t}-1$ & $\begin{array}{c}0.305 * * * \\
(0.054)\end{array}$ & $\begin{array}{l}0.316^{* * *} \\
(0.054)\end{array}$ & $\begin{array}{l}0.447 * * * \\
(0.062)\end{array}$ & $\begin{array}{c}0.467 * * * \\
(0.065)\end{array}$ \\
\hline Self-control at $\mathrm{t}-1$ & $\begin{array}{c}0.276 * * * \\
(0.068)\end{array}$ & $\begin{array}{c}0.331 * * * \\
(0.075)\end{array}$ & $\begin{array}{l}1.214 * * * \\
(0.088)\end{array}$ & $\begin{array}{c}1.306 * * * \\
(0.104)\end{array}$ \\
\hline PFA(t-1)*Self-control(t-1) & & $\begin{array}{l}-0.174 \\
(0.118)\end{array}$ & & $\begin{array}{l}-0.280^{*} \\
(0.158)\end{array}$ \\
\hline Non-prof advice $(=1)$ at $t-1$ & $\begin{array}{l}0.095^{*} \\
(0.051)\end{array}$ & $\begin{array}{l}0.096^{*} \\
(0.051)\end{array}$ & $\begin{array}{l}-0.072 \\
(0.065)\end{array}$ & $\begin{array}{l}-0.070 \\
(0.065)\end{array}$ \\
\hline $\log ($ total monthly income at $\mathrm{t})$ & $\begin{array}{c}0.322 * * * \\
(0.043)\end{array}$ & $\begin{array}{c}0.321 * * * \\
(0.043)\end{array}$ & $\begin{array}{c}0.488 * * * \\
(0.078)\end{array}$ & $\begin{array}{c}0.487 * * * \\
(0.078)\end{array}$ \\
\hline $\log ($ annual windfall income at $t)$ & $\begin{array}{c}0.049 * * * \\
(0.007)\end{array}$ & $\begin{array}{c}0.049 * * * \\
(0.007)\end{array}$ & $\begin{array}{c}0.038 * * * \\
(0.008)\end{array}$ & $\begin{array}{c}0.038 * * * \\
(0.008)\end{array}$ \\
\hline Age at $t-1$ & $\begin{array}{c}0.010 \\
(0.013)\end{array}$ & $\begin{array}{c}0.010 \\
(0.013)\end{array}$ & $\begin{array}{c}0.022 \\
(0.016)\end{array}$ & $\begin{array}{c}0.022 \\
(0.016)\end{array}$ \\
\hline Age-square at t-1 & $\begin{array}{c}-0.031 * * * \\
(0.012)\end{array}$ & $\begin{array}{c}-0.031 * * * \\
(0.012)\end{array}$ & $\begin{array}{c}0.010 \\
(0.016)\end{array}$ & $\begin{array}{c}0.010 \\
(0.016)\end{array}$ \\
\hline Own finance expectation at $\mathrm{t}-1$ & $\begin{array}{c}0.014 \\
(0.011)\end{array}$ & $\begin{array}{c}0.014 \\
(0.011)\end{array}$ & $\begin{array}{c}0.113 * * * \\
(0.016)\end{array}$ & $\begin{array}{c}0.113 * * * \\
(0.016)\end{array}$ \\
\hline Family Size at t-1 & $\begin{array}{c}0.098 * * * \\
(0.030)\end{array}$ & $\begin{array}{c}0.098 * * * \\
(0.030)\end{array}$ & $\begin{array}{l}-0.026 \\
(0.036)\end{array}$ & $\begin{array}{l}-0.027 \\
(0.036)\end{array}$ \\
\hline Married (=1) at t-1 & $\begin{array}{c}0.033 \\
(0.100)\end{array}$ & $\begin{array}{c}0.034 \\
(0.100)\end{array}$ & $\begin{array}{c}0.051 \\
(0.113)\end{array}$ & $\begin{array}{c}0.054 \\
(0.113)\end{array}$ \\
\hline Separated $(=1)$ at $\mathrm{t}-1$ & $\begin{array}{l}-0.008 \\
(0.166)\end{array}$ & $\begin{array}{l}-0.003 \\
(0.166)\end{array}$ & $\begin{array}{c}-0.447 * * \\
(0.208)\end{array}$ & $\begin{array}{c}-0.442 * * \\
(0.208)\end{array}$ \\
\hline Divorced $(=1)$ at $\mathrm{t}-1$ & $\begin{array}{l}0.202^{*} \\
(0.116)\end{array}$ & $\begin{array}{l}0.205^{*} \\
(0.116)\end{array}$ & $\begin{array}{c}-0.314 * * \\
(0.144)\end{array}$ & $\begin{array}{c}-0.308^{* *} \\
(0.144)\end{array}$ \\
\hline Widowed $(=1)$ at $\mathrm{t}-1$ & $\begin{array}{l}0.246^{* *} \\
(0.104)\end{array}$ & $\begin{array}{l}0.245^{* *} \\
(0.104)\end{array}$ & $\begin{array}{c}-0.359 * * \\
(0.176)\end{array}$ & $\begin{array}{c}-0.360 * * \\
(0.176)\end{array}$ \\
\hline Part-time employed $(=1)$ at $\mathrm{t}-1$ & $\begin{array}{c}-0.324 * * * \\
(0.099)\end{array}$ & $\begin{array}{c}-0.322 * * * \\
(0.099)\end{array}$ & $\begin{array}{c}0.007 \\
(0.103)\end{array}$ & $\begin{array}{c}0.011 \\
(0.103)\end{array}$ \\
\hline Unemployed $(=1)$ at $\mathrm{t}-1$ & $\begin{array}{c}-0.667 * * * \\
(0.093)\end{array}$ & $\begin{array}{c}-0.665 * * * \\
(0.093)\end{array}$ & $\begin{array}{l}-0.057 \\
(0.114)\end{array}$ & $\begin{array}{l}-0.052 \\
(0.114)\end{array}$ \\
\hline Retired $(=1)$ at $\mathrm{t}-1$ & $\begin{array}{c}-0.989 * * * \\
(0.095)\end{array}$ & $\begin{array}{c}-0.986 * * * \\
(0.095)\end{array}$ & $\begin{array}{l}-0.031 \\
(0.113)\end{array}$ & $\begin{array}{l}-0.028 \\
(0.113)\end{array}$ \\
\hline Save for emergency at $t-1$ & $\begin{array}{c}0.003 \\
(0.008)\end{array}$ & $\begin{array}{c}0.003 \\
(0.008)\end{array}$ & $\begin{array}{c}0.053 * * * \\
(0.012)\end{array}$ & $\begin{array}{c}0.052 * * * \\
(0.012)\end{array}$ \\
\hline Save for old-age provision at $\mathrm{t}-1$ & $\begin{array}{c}-0.036^{* * *} \\
(0.008)\end{array}$ & $\begin{array}{c}-0.036^{* * *} \\
(0.008)\end{array}$ & $\begin{array}{c}0.028^{* *} \\
(0.011)\end{array}$ & $\begin{array}{c}0.028^{* *} \\
(0.011)\end{array}$ \\
\hline Save for children education at $\mathrm{t}-1$ & $\begin{array}{c}0.019 * * \\
(0.009)\end{array}$ & $\begin{array}{c}0.019 * * \\
(0.009)\end{array}$ & $\begin{array}{c}0.209 * * * \\
(0.015)\end{array}$ & $\begin{array}{c}0.208^{* * *} \\
(0.015)\end{array}$ \\
\hline Save for bequests at $t-1$ & $\begin{array}{c}-0.012^{*} \\
(0.007)\end{array}$ & $\begin{array}{c}-0.012^{*} \\
(0.007)\end{array}$ & $\begin{array}{c}-0.063^{* * *} \\
(0.008)\end{array}$ & $\begin{array}{c}-0.063^{* * * *} \\
(0.008)\end{array}$ \\
\hline Constant & $\begin{array}{c}-1.370 * * * \\
(0.483)\end{array}$ & $\begin{array}{c}-1.360 * * * \\
(0.483)\end{array}$ & $\begin{array}{l}-0.132 \\
(0.712)\end{array}$ & $\begin{array}{l}-0.120 \\
(0.713)\end{array}$ \\
\hline Time dummies & Yes & Yes & Yes & Yes \\
\hline $\mathrm{N}$ of observations & 9,452 & 9,452 & 8,805 & 8,805 \\
\hline R-square & 0.202 & 0.202 & 0.319 & 0.319 \\
\hline
\end{tabular}

Note: The regressions control for head gender, head's education (no high school, high school, university), German nationality, residence states, and saving for vacation. The variations in sample sizes among different regressions are due to the missing values in the dependent variables. $* * *$ denotes coefficients significant at $1 \%$ level, $* *$ denotes coefficients significant at $5 \%$ level, and $*$ denotes coefficients significant at $10 \%$ level. 
Table 5.28: OLS regressions by using lagged independent variables

\begin{tabular}{|c|c|c|c|c|}
\hline \multirow{2}{*}{ Dependent variables: } & \multicolumn{2}{|c|}{ Log(Financial assets at $\mathrm{t})$} & \multicolumn{2}{|c|}{ Log(Illiquid assets at $\mathrm{t}$ ) } \\
\hline & (1) & $(2)$ & (1) & $(2)$ \\
\hline \multirow[t]{2}{*}{ PFA $(=1)$ at $t-1$} & $0.940 * * *$ & $0.996^{* * *}$ & $1.085 * * *$ & $1.122 * * *$ \\
\hline & $(0.100)$ & $(0.103)$ & $(0.130)$ & $(0.132)$ \\
\hline \multirow[t]{2}{*}{ Self-control at t-1 } & $1.992 * * *$ & $2.257 * * *$ & $1.171 * * *$ & $1.350 * * *$ \\
\hline & $(0.142)$ & $(0.164)$ & $(0.187)$ & $(0.216)$ \\
\hline \multirow[t]{2}{*}{$\operatorname{PFA}(\mathrm{t}-1) *$ Self-control(t-1) } & & $-0.823 * * *$ & & $-0.563 *$ \\
\hline & & $(0.237)$ & & $(0.301)$ \\
\hline \multirow[t]{2}{*}{ Non-prof advice $(=1)$ at t-1 } & 0.084 & 0.089 & $-0.424 * * *$ & $-0.422 * * *$ \\
\hline & $(0.100)$ & $(0.101)$ & $(0.132)$ & $(0.132)$ \\
\hline \multirow[t]{2}{*}{$\log ($ total monthly income at $\mathrm{t})$} & $0.888 * * *$ & $0.884 * * *$ & $1.191 * * *$ & $1.190 * * *$ \\
\hline & $(0.120)$ & $(0.120)$ & $(0.131)$ & $(0.131)$ \\
\hline \multirow[t]{2}{*}{$\log ($ annual windfall income at $t)$} & $0.196^{* * *}$ & $0.196 * * *$ & $0.095 * * *$ & $0.095 * * *$ \\
\hline & $(0.012)$ & $(0.012)$ & $(0.015)$ & $(0.015)$ \\
\hline \multirow[t]{2}{*}{ Age at $t-1$} & $0.071 * * *$ & $0.071 * * *$ & $0.174 * * *$ & $0.174 * * *$ \\
\hline & $(0.026)$ & $(0.026)$ & $(0.035)$ & $(0.035)$ \\
\hline \multirow[t]{2}{*}{ Age-square at t-1 } & -0.029 & -0.029 & $-0.131 * * *$ & $-0.131 * * *$ \\
\hline & $(0.026)$ & $(0.026)$ & $(0.035)$ & $(0.035)$ \\
\hline \multirow[t]{2}{*}{ Own finance expectation at $\mathrm{t}-1$} & $0.206^{* * *}$ & $0.207 * * *$ & $0.182 * * *$ & $0.183^{* * *}$ \\
\hline & $(0.025)$ & $(0.025)$ & $(0.032)$ & $(0.032)$ \\
\hline \multirow[t]{2}{*}{ Family Size at t-1 } & -0.052 & -0.051 & $0.509 * * *$ & $0.509 * * *$ \\
\hline & $(0.060)$ & $(0.060)$ & $(0.074)$ & $(0.074)$ \\
\hline \multirow[t]{2}{*}{ Married (=1) at t-1 } & -0.037 & -0.032 & 0.380 & 0.384 \\
\hline & $(0.191)$ & $(0.190)$ & $(0.260)$ & $(0.259)$ \\
\hline \multirow[t]{2}{*}{ Separated $(=1)$ at $\mathrm{t}-1$} & $-1.150 * * *$ & $-1.126^{* * *}$ & -0.384 & -0.369 \\
\hline & $(0.340)$ & $(0.339)$ & $(0.457)$ & $(0.457)$ \\
\hline \multirow[t]{2}{*}{ Divorced $(=1)$ at $\mathrm{t}-1$} & $-0.670 * * *$ & $-0.659 * * *$ & $-0.520 *$ & $-0.512 *$ \\
\hline & $(0.243)$ & $(0.242)$ & $(0.306)$ & $(0.306)$ \\
\hline \multirow[t]{2}{*}{ Widowed $(=1)$ at $\mathrm{t}-1$} & $-0.626^{* *}$ & $-0.634 * *$ & -0.316 & -0.322 \\
\hline & $(0.288)$ & $(0.287)$ & $(0.398)$ & $(0.398)$ \\
\hline \multirow[t]{2}{*}{ Part-time employed $(=1)$ at $\mathrm{t}-1$} & $-0.366^{* *}$ & $-0.354 * *$ & -0.082 & -0.073 \\
\hline & $(0.178)$ & $(0.178)$ & $(0.218)$ & $(0.218)$ \\
\hline \multirow[t]{2}{*}{ Unemployed $(=1)$ at $\mathrm{t}-1$} & $-0.603 * * *$ & $-0.592 * * *$ & -0.259 & -0.251 \\
\hline & $(0.182)$ & $(0.181)$ & $(0.221)$ & $(0.220)$ \\
\hline \multirow[t]{2}{*}{ Retired $(=1)$ at $\mathrm{t}-1$} & $-0.410 * *$ & $-0.399 * *$ & -0.067 & -0.060 \\
\hline & $(0.197)$ & $(0.196)$ & $(0.249)$ & $(0.249)$ \\
\hline \multirow[t]{2}{*}{ Save for old-age provision at $\mathrm{t}-1$} & -0.028 & -0.027 & -0.031 & -0.030 \\
\hline & $(0.017)$ & $(0.017)$ & $(0.022)$ & $(0.022)$ \\
\hline \multirow[t]{2}{*}{ Save for vacation at $\mathrm{t}-1$} & $0.060 * * *$ & $0.059 * * *$ & $0.102 * * *$ & $0.102 * * *$ \\
\hline & $(0.015)$ & $(0.015)$ & $(0.019)$ & $(0.019)$ \\
\hline Save for children education at $\mathrm{t}-1$ & $0.128 * * *$ & $0.127 * * *$ & $0.047^{*}$ & $0.046^{*}$ \\
\hline & $(0.020)$ & $(0.020)$ & $(0.026)$ & $(0.026)$ \\
\hline Save for bequests at $t-1$ & $-0.086^{* * *}$ & $-0.087 * * *$ & $0.138^{* * *}$ & $0.137 * * *$ \\
\hline & $(0.013)$ & $(0.013)$ & $(0.016)$ & $(0.016)$ \\
\hline Constant & $-6.316 * * *$ & $-6.274 * * *$ & $-12.361 * * *$ & $-12.336 * * *$ \\
\hline & $(1.088)$ & $(1.087)$ & $(1.361)$ & $(1.359)$ \\
\hline Time dummies & Yes & Yes & Yes & Yes \\
\hline $\mathrm{N}$ of observations & 10,083 & 10,083 & 10,522 & 10,522 \\
\hline R-square & 0.289 & 0.290 & 0.250 & 0.250 \\
\hline
\end{tabular}

Note: The regressions control for head gender, head's education (no high school, high school, university), German nationality, residence states, and saving for vacation. The variations in sample sizes among different regressions are due to the missing values in the dependent variables. ${ }^{* * *}$ denotes coefficients significant at $1 \%$ level, $* *$ denotes coefficients significant at $5 \%$ level, and * denotes coefficients significant at $10 \%$ level. 
Table 5.29: OLS regressions by using lagged independent variables

\begin{tabular}{|c|c|c|c|c|}
\hline \multirow{2}{*}{ Dependent variables: } & \multicolumn{2}{|c|}{ Log(Total assets at t) } & \multicolumn{2}{|c|}{ Log(Total Loan at t) } \\
\hline & (1) & (2) & (1) & $(2)$ \\
\hline \multirow[t]{2}{*}{ PFA $(=1)$ at $\mathrm{t}-1$} & $0.945 * * *$ & $1.013 * * *$ & 0.187 & $0.264 * *$ \\
\hline & $(0.096)$ & $(0.100)$ & $(0.121)$ & $(0.122)$ \\
\hline \multirow[t]{2}{*}{ Self-control at $\mathrm{t}-1$} & $1.728 * * *$ & $2.053 * * *$ & $-0.899 * * *$ & $-0.539 * * *$ \\
\hline & $(0.154)$ & $(0.187)$ & $(0.170)$ & $(0.189)$ \\
\hline \multirow[t]{2}{*}{ PFA(t-1)*Self-control(t-1) } & & $-1.023 * * *$ & & $-1.128 * * *$ \\
\hline & & $(0.246)$ & & $(0.276)$ \\
\hline \multirow[t]{2}{*}{ Non-prof advice $(=1)$ at t-1 } & $-0.241 * *$ & $-0.237 * *$ & $0.217^{*}$ & $0.224^{*}$ \\
\hline & $(0.105)$ & $(0.105)$ & $(0.121)$ & $(0.121)$ \\
\hline \multirow[t]{2}{*}{$\log ($ total monthly income at $\mathrm{t})$} & $1.120 * * *$ & $1.117 * * *$ & $1.132 * * *$ & $1.129 * * *$ \\
\hline & $(0.120)$ & $(0.119)$ & $(0.112)$ & $(0.112)$ \\
\hline \multirow[t]{2}{*}{$\log ($ annual windfall income at $t)$} & $0.121 * * *$ & $0.121 * * *$ & $0.089 * * *$ & $0.088 * * *$ \\
\hline & $(0.011)$ & $(0.011)$ & $(0.015)$ & $(0.015)$ \\
\hline \multirow[t]{2}{*}{ Age at $t-1$} & $0.121 * * *$ & $0.121 * * *$ & $0.198 * * *$ & $0.198 * * *$ \\
\hline & $(0.028)$ & $(0.028)$ & $(0.029)$ & $(0.029)$ \\
\hline \multirow[t]{2}{*}{ Age-square at t-1 } & $-0.080 * * *$ & $-0.080 * * *$ & $-0.225 * * *$ & $-0.225 * * *$ \\
\hline & $(0.028)$ & $(0.028)$ & $(0.027)$ & $(0.027)$ \\
\hline \multirow[t]{2}{*}{ Own finance expectation at $t-1$} & $0.179 * * *$ & $0.180 * * *$ & -0.018 & -0.017 \\
\hline & $(0.027)$ & $(0.027)$ & $(0.028)$ & $(0.028)$ \\
\hline \multirow[t]{2}{*}{ Family Size at t-1 } & $0.256 * * *$ & $0.256 * * *$ & $0.389 * * *$ & $0.390 * * *$ \\
\hline & $(0.061)$ & $(0.061)$ & $(0.073)$ & $(0.073)$ \\
\hline \multirow[t]{2}{*}{ Married $(=1)$ at $\mathrm{t}-1$} & 0.227 & 0.234 & $1.530 * * *$ & $1.538 * * *$ \\
\hline & $(0.204)$ & $(0.203)$ & $(0.234)$ & $(0.232)$ \\
\hline \multirow[t]{2}{*}{ Separated $(=1)$ at $\mathrm{t}-1$} & -0.625 & -0.598 & $1.043 * *$ & $1.068 * * *$ \\
\hline & $(0.386)$ & $(0.383)$ & $(0.413)$ & $(0.412)$ \\
\hline \multirow[t]{2}{*}{ Divorced $(=1)$ at $\mathrm{t}-1$} & $-0.717 * * *$ & $-0.702 * * *$ & $1.057 * * *$ & $1.075^{* * *}$ \\
\hline & $(0.264)$ & $(0.263)$ & $(0.279)$ & $(0.278)$ \\
\hline \multirow[t]{2}{*}{ Widowed $(=1)$ at $\mathrm{t}-1$} & -0.329 & -0.339 & $1.467 * * *$ & $1.455 * * *$ \\
\hline & $(0.316)$ & $(0.315)$ & $(0.313)$ & $(0.312)$ \\
\hline \multirow[t]{2}{*}{ Part-time employed $(=1)$ at t-1 } & -0.061 & -0.045 & $-0.851 * * *$ & $-0.833 * * *$ \\
\hline & $(0.177)$ & $(0.176)$ & $(0.218)$ & $(0.218)$ \\
\hline \multirow[t]{2}{*}{ Unemployed $(=1)$ at $\mathrm{t}-1$} & $-0.484 * *$ & $-0.469 * *$ & $-1.280 * * *$ & $-1.264 * * *$ \\
\hline & $(0.191)$ & $(0.190)$ & $(0.222)$ & $(0.222)$ \\
\hline \multirow[t]{2}{*}{ Retired $(=1)$ at $\mathrm{t}-1$} & -0.005 & 0.007 & $-0.703 * * *$ & $-0.688 * * *$ \\
\hline & $(0.199)$ & $(0.198)$ & $(0.245)$ & $(0.245)$ \\
\hline \multirow[t]{2}{*}{ Save for old-age provision at $\mathrm{t}-1$} & $-0.039 * *$ & $-0.038 * *$ & $-0.092 * * *$ & $-0.091 * * *$ \\
\hline & $(0.017)$ & $(0.017)$ & $(0.020)$ & $(0.020)$ \\
\hline \multirow[t]{2}{*}{ Save for vacation at $\mathrm{t}-1$} & $0.081 * * *$ & $0.080 * * *$ & $0.035^{*}$ & $0.034^{*}$ \\
\hline & $(0.015)$ & $(0.015)$ & $(0.018)$ & $(0.018)$ \\
\hline Save for children education at $t-1$ & $0.109 * * *$ & $0.108 * * *$ & $-0.078 * * *$ & $-0.079 * * *$ \\
\hline & $(0.021)$ & $(0.021)$ & $(0.022)$ & $(0.022)$ \\
\hline Save for bequests at $t-1$ & $0.022 *$ & $0.021^{*}$ & $0.333 * * *$ & $0.332 * * *$ \\
\hline & $(0.013)$ & $(0.013)$ & $(0.015)$ & $(0.015)$ \\
\hline Constant & $-7.836 * * *$ & $-7.791 * * *$ & $-11.551 * * *$ & $-11.492 * * *$ \\
\hline & $(1.148)$ & $(1.144)$ & $(1.162)$ & $(1.159)$ \\
\hline Time dummies & Yes & Yes & Yes & Yes \\
\hline $\mathrm{N}$ of observations & 10,532 & 10,532 & 10,146 & 10,146 \\
\hline R-square & 0.294 & 0.296 & 0.263 & 0.265 \\
\hline
\end{tabular}

Note: The regressions control for head gender, head's education (no high school, high school, university), German nationality, residence states, and saving for vacation. The variations in sample sizes among different regressions are due to the missing values in the dependent variables. $* * *$ denotes coefficients significant at $1 \%$ level, $* *$ denotes coefficients significant at $5 \%$ level, and * denotes coefficients significant at $10 \%$ level. 


\section{Chapter 6. Conclusion}

This final chapter will summarize results and contributions of this study. Section 6.1 will discuss the empirical findings of this study and provide suggestions to policy makers. Section 6.2 will describe the limitations of measurement and estimations. Section 6.3 will discuss the contributions of this study to the literature.

\subsection{Implications}

This study has three key findings that can help policy-makers design interventions or programs to improve household financial behaviors. The first finding is the significant positive relationship between self-control ability and saving behaviors. This finding suggests that the interventions to enhance self-control ability could help households deal with their finance and increase savings. The psychological literature suggests that selfcontrol can be built up through regular exercise (Baumeister, Gailliot, DeWall, \& Oaten, 2006). One suggestion is to use the practice of budget recording as an exercise to help households improve self-control in financial management.

The second finding is the significant positive relationship between professional financial advice and saving behaviors. Professional financial advisors can contribute to 
household financial management in several ways. First, professional financial advisors can make use of their financial expertise to help clients make comprehensive financial plans. Second, in a complicated financial market, professional financial advisors have the information advantage and network to help clients make informed decisions. Empirical results in this study provide evidence to support public policies which encourage households to seek professional financial advice.

The third finding of this study is that professional financial advice can moderate the relationship between self-control ability and saving behaviors. With technology development, banks have designed new products and services to help consumers improve their financial management, such as text message warnings, email alerts, automated bill payment, and automated minimum payment. Professional financial advisors can encourage clients to make use of these bank products and services, which can help them monitor any negative events and fix potential problems in a timely manner. For people with self-control problems, professional financial advice can serve them by suggesting tips and practices to avoid potential self-control failures, such as commitment devices and automatic saving programs.

\subsection{Limitations}

This study has a variety of limitations in measurements and estimations. The first limitation is how respondents understand the question about advice seeking. Many questions in SAVE have provided clear time range such as "during the last 12 months" or "in the previous year" or "at the end of the period year."Among 3,941 households in the 
2005-2009 panel, 353 respondents switch from getting PFA to not getting PFA, and 822 respondents have mixed patterns in their reported PFA-seeking behaviors. The most possible reason for mixed patterns in the reported PFA-seeking behaviors is that those respondents may only recall their recent advice-seeking behaviors in the previous year. Moreover, 591 respondents always report that they get PFA only if they are in the sample. The lack of information about the accurate time of getting PFA is a limitation in the dataset and this study. For future research, it is important to collect the information about the time of getting PFA in order to estimate the effect of PFA on financial behaviors.

Using factor analysis, there is some subjectivity in the interpretation of a common factor. In other words, the aggregate measure of self-control may capture some other common factor of three behavioral proxies. For example, the common factor may be capturing household economic resources, since households with higher economic resources tend to report higher saving habit and less overdraft behaviors. However, economic resources have difficulties in explaining smoking behavior. The uncertainty in the measurement of self-control is a potential problem in this study.

The self-reported financial variables may contain measurement error. Some respondents skip some sensitive financial questions, and this phenomenon results in missing data. In order to deal with missing data, the data center has implemented a Markov Chain Monte Carlo multiple imputation procedure to assign plausible values to missing variables and provides five imputed datasets for each wave. This study uses the method of multiple imputation estimation in empirical analysis. Moreover, some 
respondents may provide inaccurate answers to some questions due to a variety of reasons. This kind of measurement error may cause problems which is difficult to be detected.

The lack of a valid instrumental variable for the choice of getting professional financial advice is another limitation of this study. I choose a fixed-effects model to control for unobserved time-invariant effects. However, there is potential endogeneity issue in the choice of seeking professional financial advice. I have searched for instrumental variables to deal with this problem, such as the usage of internet. The usage of internet is expected to be uncorrelated with saving behaviors, but may affect the choice of seeking professional financial advice by providing convenience in information search. However, the correlation coefficient between the usage of internet and seeking professional financial advice is only 0.062 , and tests show that the usage of internet is a weak IV for the choice of getting professional financial advice.

\subsection{Contributions}

The first contribution of this study is to provide evidence about the positive relationship between professional financial advice (PFA) and saving behaviors over time. Using a fixed-effects model, my empirical results show that there is a significant positive relationship between PFA and short-run saving behaviors, such as savings out of windfall, annual total savings, and own pension contribution. Moreover, there is a significant positive relationship between PFA and long-run financial outcomes, such as emergency funds, financial assets, illiquid assets and total assets. 
In the literature, studies show that self-control is related with positive outcomes, such as academic achievement and interpersonal success (Tangney et al., 2004). This study provides evidence about the positive relationship between self-control ability and saving behaviors, such as annual total savings, emergency funds, financial assets and total assets.

The main contribution of this study is to link the relationship between getting professional financial advice and saving behaviors with the self-control ability. The theoretical model hypothesizes that people who are prone to self-control failures can be helped more by getting professional financial advice. Empirical findings provide some evidence to support this hypothesis. The interaction of PFA and self-control has a significant negative relationship with financial assets and total loans, at the 0.1 significance level. Moreover, the interaction of PFA and self-control has a negative but insignificant relationship with savings out of windfall, emergency funds, illiquid assets and total assets. All the significant coefficients are consistent with the third hypothesis about the interaction of PFA and self-control on saving behaviors. This finding suggests that households with lower levels of self-control can benefit more from getting professional financial advice than those with higher levels of self-control.

As a final note, this study finds some but limited evidences to support three hypotheses by using a fixed-effects model. Future research about the effect of professional financial advice calls for improvement in survey design and accurate measurement of advice-seeking behaviors. 


\section{References}

Ameriks, J., Caplin, A., Leahy, J., \& Tyler, T. (2007). Measuring Self-Control Problems. The American Economic Review, 97(3), 966-972.

Angeletos, G.-M., Laibson, D., Repetto, A., Tobacman, J., \& Weinberg, S. (2001). The Hyperbolic Consumption Model: Calibration, Simulation, and Empirical Evaluation. The Journal of Economic Perspectives, 15(3), 47-68.

Ariely, D., \& Wertenbroch, K. (2002). Procrastination, Deadlines, and Performance: SelfControl by Precommitment. Psychological Science, 13(3), 219-224.

Arkes, H. R., Joyner, C. A., Pezzo, M. V., Nash, J. G., Siegel-Jacobs, K., \& Stone, E. (1994). The Psychology of Windfall Gains. Organizational Behavior and Human Decision Processes, 59(3), 331-347. doi: http://dx.doi.org/10.1006/obhd.1994.1063

Babiarz, P., \& Robb, C. (2013). Financial Literacy and Emergency Saving. Journal of Family and Economic Issues, 1-11. doi: 10.1007/s10834-013-9369-9

Bagarozzi, J. I., \& Bagarozzi, D. A. (1980). Financial Counseling: A Self Control Model for the Family. Family Relations, 29(3), 396-403. doi: 10.2307/583863

Barber, B. M., \& Odean, T. (2000). Trading is Hazardous to your Wealth: The Common Stock Investment Performance of Individual Investors. The Journal of Finance, 55(2), 773-806.

Barber, B. M., \& Odean, T. (2008). All that Glitters: The Effect of Attention and News on the Buying Behavior of Individual and Institutional Investors. Review of Financial Studies, 21(2), 785-818.

Baumeister, R. F. (2002). Yielding to Temptation: Self-Control Failure, Impulsive Purchasing, and Consumer Behavior. Journal of Consumer Research, 28(4), 670676. doi: $10.1086 / 338209$

Baumeister, R. F., Gailliot, M., DeWall, C. N., \& Oaten, M. (2006). Self-Regulation and Personality: How Interventions Increase Regulatory Success, and How Depletion Moderates the Effects of Traits on Behavior. Journal of Personality, 74(6), 17731802 . 
Bergstresser, D., Chalmers, J. M. R., \& Tufano, P. (2009). Assessing the Costs and Benefits of Brokers in the Mutual Fund Industry. Review of Financial Studies, 22(10), 4129-4156. doi: 10.1093/rfs/hhp022

Black, K., Ciccotello, C. S., \& Skipper, H. D. (2002). Issues in Comprehensive Personal Financial Planning. Financial Services Review, 11(1), 1-9.

Bluethgen, R., Gintschel, A., Hackethal, A., \& Mueller, A. (2008). Financial Advice and Individual Investors' Portfolios. Available at SSRN 968197.

Borghans, L., Duckworth, A. L., Heckman, J. J., \& Ter Weel, B. (2008). The Economics and Psychology of Personality traits. Journal of Human Resources, 43(4), 9721059.

Börsch-Supan, A., Coppola, M., Essig, L., Eymann, A., \& Schunk, D. (2008). The German SAVE study: Design and Results

Börsch-Supan, A., \& Wilke, C. B. (2004). The German Public Pension System: How it was, How it will be: National Bureau of Economic Research.

Breusch, T. S., \& Pagan, A. R. (1980). The Lagrange Multiplier Test and its Applications to Model Specification in Econometrics. The Review of Economic Studies, 239253.

Browning, M., \& Lusardi, A. (1996). Household Saving: Micro Theories and Micro Facts. Journal of Economic Literature, 34(4), 1797-1855. doi: 10.2307/2729595

Campbell, J. Y. (2006). Household Finance. The Journal of Finance, 61(4), 1553-1604.

Collins, J. M. (2010). A Review of Financial Advice Models and the Take-Up of Financial Advice. Center for Financial Security WP, 10, 5.

Cummings, B. F., \& James, R. N. (2013). The Impact of Financial Advisors on the Subsequent Wealth of Older Adults. Paper presented at the Academy of Financial Services (AFS), , Chicago, IL.

DellaVigna, S., \& Paserman, M. D. (2006). Job Search and Impatience. Journal of Labor Economics, 23(3).

Elmerick, S. A., Montalto, C. P., \& Fox, J. J. (2002). Use of Financial Planners by US Households. Financial Services Review, 11, 217-231.

Fabrigar, L. R., Wegener, D. T., MacCallum, R. C., \& Strahan, E. J. (1999). Evaluating the Use of Exploratory Factor Analysis in Psychological Research. Psychological methods, 4(3), 272. 
Fernandes, D., Lynch, J. G., \& Netemeyer, R. (2013). Financial Literacy, Financial Education and Downstream Financial Behaviors. Management Science, in press.

Finke, M., Huston, S., \& Waller, W. (2009). Do Contracts Influence Comprehensive Financial Advice? Financial Services Review, 18(3).

Fischer, R., \& Gerhardt, R. (2007). Investment Mistakes of Individual Investors and the Impact of Financial Advice. Paper presented at the 20th Australasian Finance \& Banking Conference.

Floyd, F. J., \& Widaman, K. F. (1995). Factor Analysis in the Development and Refinement of Clinical Assessment Instruments. Psychological assessment, 7(3), 286.

Foerster, S., Linnainmaa, J., Melzer, B., \& Previtero, A. (2014). The Costs and Benefits of Financial Advice. 2014 AEA discussing paper in the session of Household Finance.

Frederick, S., Loewenstein, G., \& O'Donoghue, T. (2002). Time Discounting and Time Preference: A Critical Review. Journal of economic literature, 40(2), 351-401.

Friedman, M. (1957). A Theory of the Consumption Function. NBER Books.

Fuchs, V. R. (1982). Time Preference and Health: An Exploratory Study. In R. F. Victor (Ed.), Economic Aspects of Health. Chicago: University of Chicago Press.

Fudenberg, D., \& Levine, D. K. (2006). A Dual-Self Model of Impulse Control. The American Economic Review, 96(5), 1449-1476. doi: 10.2307/30034982

Fudenberg, D., \& Levine, D. K. (2012). Timing and Self-Control. Econometrica, 80(1), $1-42$.

Fulbrook, M. (2011). A History of Germany 1918-2008: The Divided Nation: John Wiley \& Sons.

Gathergood, J. (2012). Self-Control, Financial Literacy and Consumer Overindebtedness. Journal of Economic Psychology, 33(3), 590-602.

Grable, J. E., \& Joo, S.-h. (1999). Financial Help-Seeking Behavior: Theory and Implications. Financial Counseling and Planning, 10(1), 13-24.

Green, L., Fry, A. F., \& Myerson, J. (1994). Discounting of Delayed Rewards: A LifeSpan Comparison. Psychological Science (Wiley-Blackwell), 5(1), 33-36.

Green, L., Myerson, J., \& Ostaszewski, P. (1999). Discounting of Delayed Rewards across the Life Span: Age Differences in Individual Discounting Functions. 
Behavioural Processes, 46(1), 89-96. doi: http://dx.doi.org/10.1016/S03766357(99)00021-2

Greene, W. H. (2003). Econometric Analysis (5th ed.): Ed.. Upper Saddle River, NJ.

Gul, F., \& Pesendorfer, W. (2004). Self-Control and the Theory of Consumption. Econometrica, 72(1), 119-158.

Hackethal, A., Haliassos, M., \& Jappelli, T. (2012). Financial Advisors: A Case of Babysitters? Journal of Banking \& Finance, 36(2), 509-524.

Hanna, S. D., \& Lindamood, S. (2010). Quantifying the Economic Benefits of Personal Financial Planning. Financial Services Review, 19(2).

Harman, H. H. (1976). Modern Factor Analysis: University of Chicago Press.

Hastings, J. S., Madrian, B. C., \& Skimmyhorn, W. L. (2013). Financial Literacy, Financial Education, and Economic Outcomes. Annual Review of Economics, 5(1), 347-373. doi: doi:10.1146/annurev-economics-082312-125807

Hausman, J. A. (1978). Specification Tests in Econometrics. Econometrica: Journal of the Econometric Society, 1251-1271.

Heath, C., \& Soll, J. B. (1996). Mental Budgeting and Consumer Decisions. Journal of Consumer Research, 23(1), 40-52. doi: 10.2307/2489664

Hersch, J. (2005). Smoking Restrictions as a Self-Control Mechanism. Journal of Risk and Uncertainty, 31(1), 5-21.

Hershfield, H. E., Goldstein, D. G., Sharpe, W. F., Fox, J., Yeykelis, L., Carstensen, L. L., \& Bailenson, J. N. (2011). Increasing Saving Behavior through AgeProgressed Renderings of the Future Self. Journal of Marketing Research, 48(SPL), S23-S37.

Hilgert, M. A., Hogarth, J. M., \& Beverly, S. G. (2003). Household Financial Management: The Connection between Knowledge and Behavior. Fed. Res. Bull., 89,309 .

Joo, S. H., \& Grable, J. E. (2001). Factors Associated with Seeking and Using Professional Retirement-Planning Help. Family and Consumer Sciences Research Journal, 30(1), 37-63.

Kaplan, S. N., Klebanov, M. M., \& Sorensen, M. (2012). Which CEO Characteristics and Abilities Matter? The Journal of Finance, 67(3), 973-1007. 
Khwaja, A., Silverman, D., \& Sloan, F. (2007). Time Preference, Time Discounting, and Smoking Decisions. Journal of Health Economics, 26(5), 927-949. doi: http://dx.doi.org/10.1016/j.jhealeco.2007.02.004

Kramer, M. M. (2012). Financial Advice and Individual Investor Portfolio Performance. Financial Management, 41(2), 395-428.

Krausz, M., \& Paroush, J. (2002). Financial Advising in the Presence of Conflict of Interests. Journal of Economics and Business, 54(1), 55-71. doi: http://dx.doi.org/10.1016/S0148-6195(01)00057-1

Kuhn, A. (2013). Inequality Perceptions, Distributional Norms, and Redistributive Preferences in East and West Germany. German Economic Review, 14(4), 483499.

Lachance, M. E., \& Tang, N. (2012). Financial Advice and Trust. Financial Services Review, 21(3), 209.

Laibson, D. (1997). Golden Eggs and Hyperbolic Discounting. The Quarterly Journal of Economics, 112(2), 443-478. doi: 10.1162/003355397555253

Laibson, D. I., Repetto, A., Tobacman, J., Hall, R. E., Gale, W. G., \& Akerlof, G. A. (1998). Self-Control and Saving for Retirement. Brookings Papers on Economic Activity, 1998(1), 91-196.

Lin, Q., \& Lee, J. (2004). Consumer Information Search when Making Investment Decisions. Financial Services Review, 13, 319-332.

Loewenstein, G. (1996). Out of Control: Visceral Influences on Behavior. Organizational Behavior and Human Decision Processes, 65(3), 272-292.

Lusardi, A. (2004). Saving and the Effectiveness of Financial Education. In O. S. Mitchell \& S. P. Utkus (Eds.), Pension Design and Structure: New Lessons from Behavioral Finance (pp. 157-184): Oxford University Press.

Lusardi, A., \& Mitchell, O. S. (2006). Financial Literacy and Planning: Implications for Retirement Wellbeing: National Bureau of Economic Research.

Lusardi, A., \& Mitchell, O. S. (2007). Baby Boomer Retirement Security: The Roles of Planning, Financial Literacy, and Housing Wealth. Journal of monetary

Economics, 54(1), 205-224.

Lusardi, A., \& Mitchelli, O. (2007). Financial Literacy and Retirement Preparedness: Evidence and Implications for Financial Education. Business Economics, 42(1), $35-44$. 
Lusardi, A., Schneider, D. J., \& Tufano, P. (2011). Financially Fragile Households: Evidence and Implications: National Bureau of Economic Research, Inc.

Marsden, M., Zick, C. D., \& Mayer, R. N. (2011). The Value of Seeking Financial Advice. Journal of Family and Economic Issues, 32(4), 625-643.

Mastrobuoni, G., \& Weinberg, M. (2009). Heterogeneity in Intra-Monthly Consumption Patterns, Self-Control, and Savings at Retirement. American Economic Journal: Economic Policy, 1(2), 163-189. doi: 10.2307/25760044

McKenzie, C. R., \& Liersch, M. J. (2011). Misunderstanding Savings Growth: Implications for Retirement Savings Behavior. Journal of Marketing Research, 48(SPL), S1-S13.

McLellan, A. C. (2012). Foundations of Financial Planning: An Overview Financial Advisor Series, A. C. McLellan (Ed.)

Metcalfe, J., \& Mischel, W. (1999). A Hot/Cool-System Analysis of Delay of Gratification: Dynamics of Willpower. Psychological Review, 106(1), 3-19.

Mischel, W., Ebbesen, E. B., \& Zeiss, A. R. (1972). Cognitive and Attentional Mechanisms in Delay of Gratification. Journal of Personality and Social Psychology, 21(2), 204-218.

Mischel, W., Shoda, Y., \& Rodriguez, M. I. (1989). Delay of Gratification in Children. Science, 244(4907), 933-938.

Mitchell, S. H. (1999). Measures of Impulsivity in Cigarette Smokers and Non-smokers. Psychopharmacology, 146(4), 455-464.

Montalto, C. P., \& Sung, J. (1996). Multiple Imputation in the 1992 Survey of Consumer Finances. Financial Counseling and Planning, 7(1), 133-146.

Mullainathan, S., Noeth, M., \& Schoar, A. (2012). The Market for Financial Advice: An Audit Study. NBER Working Paper(w17929).

Munnell, A., Webb, A., \& Golub-Sass, F. (2010). Is There Really a Retirement Savings Crisis? An NRRI Analysis. Center for Retirement Research at Boston College.

Muraven, M., \& Baumeister, R. F. (2000). Self-Regulation and Depletion of Limited Resources: Does Self-Control Resemble a Muscle? Psychological bulletin, $126(2), 247$.

O'Donoghue, T., \& Rabin, M. (1999). Doing It Now or Later. The American Economic Review, 89(1), 103-124. doi: 10.2307/116981 
O'Donoghue, T., \& Rabin, M. (2001). Choice and Procrastination. The Quarterly Journal of Economics, 116(1), 121-160.

Oaten, M., \& Cheng, K. (2007). Improvements in Self-Control from Financial Monitoring. Journal of Economic Psychology, 28(4), 487-501. doi: http://dx.doi.org/10.1016/j.joep.2006.11.003

Ockenfels, A., \& Weimann, J. (1999). Types and Patterns: An Experimental East-WestGerman Comparison of Cooperation and Solidarity. Journal of Public Economics, 71(2), 275-287.

Odean, T. (1998). Are Investors Reluctant to Realize their Losses? The Journal of Finance, 53(5), 1775-1798.

Otto, P. E., Davies, G. B., \& Chater, N. (2007). Note on Ways of Saving: Mental Mechanisms as Tools for Self-Control? Global Business and Economics Review, 9(2), 227-254.

Palmer, S., \& Whybrow, A. (2007). Handbook of Coaching Psychology: A Guide for Practitioners. London: Routledge.

Redden, J. P., \& Haws, K. L. (2013). Healthy Satiation: The Role of Decreasing Desire in Effective Self-Control. Journal of Consumer Research, 39(5), 1100-1114.

Remund, D. L. (2010). Financial Literacy Explicated: The Case for a Clearer Definition in an Increasingly Complex Economy. Journal of Consumer Affairs, 44(2), 276295.

Romal, J. B., \& Kaplan, B. J. (1995). Difference in Self-Control among Spenders and Savers. Psychology: A Quarterly Journal of Human Behavior, 32(2), 8-17.

Rubin, D. B. (1987). Multiple Imputation for Nonresponse in Surveys: Wiley.

Scharff, R. L., \& Viscusi, W. K. (2011). Heterogeneous Rates of Time Preference and the Decision to Smoke. Economic Inquiry, 49(4), 959-972.

Schelling, T. C. (1984). Self-Command in Practice, in Policy, and in a Theory of Rational Choice. The American Economic Review, 74(2), 1-11.

Schunk, D. (2008). A Markov chain Monte Carlo algorithm for multiple imputation in large surveys. AStA Advances in Statistical Analysis, 92(1), 101-114. doi: $10.1007 / \mathrm{s} 10182-008-0053-6$

Schunk, D. (2009). What Determines the Savings Behavior of German Households? An Examination of Saving Motives and Saving Decisions. Journal of Economics and Statistics, 229(4), 467-491. 
Shefrin, H., \& Statman, M. (1985). The Disposition to Sell Winners too Early and Ride Losers too Long: Theory and Evidence. The Journal of Finance, 40(3), 777-790.

Shefrin, H. M., \& Thaler, R. H. (1988). The Behavioral Life-Cycle Hypothesis. Economic Inquiry, 26(4), 609-643.

Shiller, R. J. (2009). How about a Stimulus for Financial Advice? The New York Times. Retrieved from doi:http://www.nytimes.com/2009/01/18/business/economy/18view.html?_r=2\&

Smith, H., Finke, M., \& Huston, S. (2012). The Influence of Financial Sophistication and Financial Planners on Roth IRA Ownership. Journal of Financial Service Professionals, 66(6).

Stango, V., \& Zinman, J. (2009). What Do Consumers Really Pay on Their Checking and Credit Card Accounts? Explicit, Implicit, and Avoidable Costs. The American Economic Review, 99(2), 424-429. doi: 10.2307/25592435

Stigler, G. J. (1961). The Economics of Information. Journal of Political Economy, 69(3), 213-225. doi: 10.2307/1829263

Strotz, R. (1956). Myopia and Inconsistency in Dynamic Utility Maximization. The Review of Economic Studies, 23(3), 165-180.

Tang, N., \& Lachance, M.-E. (2012). Financial Advice: What about Low Income Consumers? Journal of Personal Finance, 11(2).

Tangney, J. P., Baumeister, R. F., \& Boone, A. L. (2004). High Self-Control Predicts Good Adjustment, Less Pathology, Better Grades, and Interpersonal Success. Journal of Personality, 72(2), 271-324.

Thaler, R. (1981). Some Empirical Evidence on Dynamic Inconsistency. Economics Letters, 8(3), 201-207.

Thaler, R. H. (1990). Anomalies: Saving, Fungibility, and Mental Accounts. The Journal of Economic Perspectives, 193-205.

Thaler, R. H., \& Benartzi, S. (2004). Save More Tomorrow ${ }^{\mathrm{TM}}$ : Using Behavioral Economics to Increase Employee Saving. Journal of Political Economy, 112(S1), S164-S187. doi: $10.1086 / 380085$

Thaler, R. H., \& Shefrin, H. M. (1981). An Economic Theory of Self-Control. The Journal of Political Economy, 89(2), 392-406.

Van Roye, B. (2011). Financial Stress and Economic Activity in Germany and the Euro Area: Kiel Working Papers. 
Wärneryd, K.-E. (1999). The Psychology of Saving: A Study on Economic Psychology: Edward Elgar Publishing.

Ziegelmeyer, M. (2009). Documentation of the Logical Imputation Using the Panel Structure of the 2003-2008 German SAVE Survey. 


\section{Appendix: Proof of Hypothesis 3}

The formula of the optimal saving rate is:

$$
a=\frac{\delta}{1+(1-\delta) \cdot \gamma}
$$

For two agents with different self-control cost, $\gamma_{1}(P F A=0)<\gamma_{2}(P F A=0)$, their optimal saving rates are:

$$
\begin{aligned}
& a_{1}(P F A=0)=\frac{\delta}{1+(1-\delta) \cdot \gamma_{1}(P F A=0)} \\
& a_{2}(P F A=0)=\frac{\delta}{1+(1-\delta) \cdot \gamma_{2}(P F A=0)}
\end{aligned}
$$

After getting professional financial advice, their saving rates will change accordingly.

$$
\begin{aligned}
& a_{1}(P F A>0)=\frac{\delta}{1+(1-\delta) \cdot \gamma_{1}(P F A>0)} \\
& a_{2}(P F A>0)=\frac{\delta}{1+(1-\delta) \cdot \gamma_{2}(P F A>0)}
\end{aligned}
$$

For simplicity, I use PFA to represent getting PFA from now on.

$$
\begin{gathered}
a_{1}=a_{1}(P F A=0) \\
a_{2}=a_{2}(P F A=0) \\
a_{1}(P F A)=a_{1}(P F A>0) \\
a_{2}(P F A)=a_{2}(P F A>0)
\end{gathered}
$$


In order to compare $\Delta a_{1}=a_{1}(P F A)-a_{1}$ and $\Delta a_{2}=a_{2}(P F A)-a_{2}$, I calculate their ratio as below.

$$
\frac{\Delta a_{1}}{\Delta a_{2}}=\frac{a_{1}(P F A)-a_{1}}{a_{2}(P F A)-a_{2}}=\frac{\frac{\delta}{1+(1-\delta) \cdot \gamma_{1}(P F A)}-\frac{\delta}{1+(1-\delta) \cdot \gamma_{1}}}{\frac{\delta}{1+(1-\delta) \cdot \gamma_{2}(P F A)}-\frac{\delta}{1+(1-\delta) \cdot \gamma_{2}}}
$$

Therefore, the ratio can be simplified as:

$$
\frac{\Delta a_{1}}{\Delta a_{2}}=\frac{\gamma_{1}-\gamma_{1}(P F A)}{\gamma_{2}-\gamma_{2}(P F A)} \times \frac{1+(1-\delta) \cdot \gamma_{2}(P F A)}{1+(1-\delta) \cdot \gamma_{1}(P F A)} \times \frac{1+(1-\delta) \cdot \gamma_{2}}{1+(1-\delta) \cdot \gamma_{1}}
$$

Case (i): when $\gamma_{1}(P F A)=\gamma_{2}(P F A)=\gamma$, which means that agents have the same self-control cost after getting professional financial advice.

$$
\frac{\Delta a_{1}}{\Delta a_{2}}=\frac{\gamma_{1}-\gamma_{1}(P F A)}{\gamma_{2}-\gamma_{2}(P F A)} \times \frac{1+(1-\delta) \cdot \gamma_{2}}{1+(1-\delta) \cdot \gamma_{1}}=\frac{\gamma_{1}-\gamma}{\gamma_{2}-\gamma} \times \frac{1+(1-\delta) \cdot \gamma_{2}}{1+(1-\delta) \cdot \gamma_{1}}
$$

Therefore, the difference between the numerator and the denominator is:

$$
\begin{aligned}
& \left(\gamma_{1}-\gamma\right)\left(1+(1-\delta) \cdot \gamma_{2}\right)-\left(\gamma_{2}-\gamma\right)\left(1+(1-\delta) \cdot \gamma_{1}\right) \\
= & \gamma_{1}-\gamma+\left(\gamma_{1}-\gamma\right)(1-\delta) \cdot \gamma_{2}-\left(\gamma_{2}-\gamma\right)-\left(\gamma_{2}-\gamma\right)(1-\delta) \cdot \gamma_{1} \\
= & \gamma_{1}-\gamma_{2}+(1-\delta)\left[\gamma \cdot \gamma_{1}-\gamma \cdot \gamma_{2}\right] \\
= & {[1+(1-\delta) \gamma] \cdot\left(\gamma_{1}-\gamma_{2}\right) }
\end{aligned}
$$

From $\gamma_{1}<\gamma_{2}$, we can get that $\left(\gamma_{1}-\gamma\right)\left(1+(1-\delta) \cdot \gamma_{2}\right)-\left(\gamma_{2}-\gamma\right)(1+$ $1-\delta \cdot \gamma 1<0$

Therefore, $\frac{\Delta a_{1}}{\Delta a_{2}}<1$, that is $\Delta a_{1}<\Delta a_{2}$.

Case (ii): when $\gamma_{1}(P F A)>\gamma_{2}(P F A)$, which means that if agents 2 has higher self-control cost than agent 1 , agent 2 will have lower self-control cost than agent 1 after getting professional financial advice. 


$$
\frac{\Delta a_{1}}{\Delta a_{2}}=\frac{\gamma_{1}-\gamma_{1}(P F A)}{\gamma_{2}-\gamma_{2}(P F A)} \times \frac{1+(1-\delta) \cdot \gamma_{2}(P F A)}{1+(1-\delta) \cdot \gamma_{1}(P F A)} \times \frac{1+(1-\delta) \cdot \gamma_{2}}{1+(1-\delta) \cdot \gamma_{1}}
$$

We can also get that $\frac{1+(1-\delta) \cdot \gamma_{2}(P F A)}{1+(1-\delta) \cdot \gamma_{1}(P F A)} \times \frac{\gamma_{1}-\gamma_{1}(P F A)}{\gamma_{2}-\gamma_{2}(P F A)} \times \frac{1+(1-\delta) \cdot \gamma_{2}}{1+(1-\delta) \cdot \gamma_{1}}<1$

Therefore, $\Delta a_{1}<\Delta a_{2}$.

Case (iii): when $\gamma_{1}(P F A)<\gamma_{2}(P F A)$, which means that if agents 2 has higher self-control cost than agent 1 , agent 2 will still have higher self-control cost than agent 1 after getting professional financial advice.

$$
\frac{\Delta a_{1}}{\Delta a_{2}}=\frac{\gamma_{1}-\gamma_{1}(P F A)}{\gamma_{2}-\gamma_{2}(P F A)} \times \frac{1+(1-\delta) \cdot \gamma_{2}(P F A)}{1+(1-\delta) \cdot \gamma_{1}(P F A)} \times \frac{1+(1-\delta) \cdot \gamma_{2}}{1+(1-\delta) \cdot \gamma_{1}}
$$

It is more difficult to get the relationship between $\Delta a_{1}$ and $\Delta a_{2}$ in this case. We can expand the numerator and denominator, and then calculate their difference.

Numerator - Denominator

$$
\begin{aligned}
& =\left[\gamma_{1}-\gamma_{1}(P F A)\right] \times\left[1+(1-\delta) \cdot \gamma_{2}(P F A)\right] \times\left[1+(1-\delta) \cdot \gamma_{2}\right]-\left[\gamma_{2}-\gamma_{2}(P F A)\right] \times \\
& {\left[1+(1-\delta) \cdot \gamma_{1}(P F A)\right] \times\left[1+(1-\delta) \cdot \gamma_{1}\right]} \\
& =\left[\gamma_{1}-\gamma_{1}(P F A)-\gamma_{2}+\gamma_{2}(P F A)\right]+2(1-\delta) \cdot\left[\gamma_{1} \cdot \gamma_{2}(P F A)-\gamma_{2} \cdot \gamma_{1}(P F A)\right]+ \\
& (1-\delta)^{2} \cdot\left\{\gamma_{1} \cdot \gamma_{2}(P F A) \cdot\left[\gamma_{1}(P F A)+\gamma_{2}\right]-\gamma_{1}(P F A) \cdot \gamma_{2} \cdot\left[\gamma_{1}+\gamma_{2}(P F A)\right]\right\}
\end{aligned}
$$

Under two more conditions (1) $\gamma_{1}-\gamma_{1}(P F A)<\gamma_{2}-\gamma_{2}(P F A)$; (2) $\gamma_{1}$. $\gamma_{2}(P F A)<\gamma_{2} \cdot \gamma_{1}(P F A)$, we can get that $\Delta a_{1}<\Delta a_{2}$ in this case ${ }^{5}$.

\footnotetext{
${ }^{5}$ From condition (1), we can get that the first term is negative, that is $\gamma_{1}-\gamma_{1}(P F A)-\gamma_{2}+\gamma_{2}(P F A)<0$. From condition (2) and that fact that the self-control cost parameter $\gamma$ is between 0 and 1 , we can get that the sum of the second and third terms are negative, that is $2(1-\delta) \cdot\left[\gamma_{1} \cdot \gamma_{2}(P F A)-\gamma_{2} \cdot \gamma_{1}(P F A)\right]+$ $(1-\delta)^{2} \cdot\left\{\gamma_{1} \cdot \gamma_{2}(P F A) \cdot\left[\gamma_{1}(P F A)+\gamma_{2}\right]-\gamma_{1}(P F A) \cdot \gamma_{2} \cdot\left[\gamma_{1}+\gamma_{2}(P F A)\right]\right\}<0$.
} 
Condition (1) means that for agent 2 with higher self-control cost than agent 1 , after getting professional financial advice, the change in agent 2's self-control cost is larger than the change in agent 1's self-control cost.

Condition (2) is equivalent to $\frac{\gamma_{2}(P F A)}{\gamma_{1}(P F A)}<\frac{\gamma_{2}}{\gamma_{1}}$, which means that the ratio between two agents' self-control costs becomes smaller after getting PFA.

These two more conditions means that getting professional financial advice can bring the gap in agents' self-control costs closer. Under those conditions, even if agent 2's self-control cost is still larger than agent 1 after getting PFA, we can get that $\Delta a_{1}<$ $\Delta a_{2}$ holds.

Actually, if we assume that the discount factor $\delta$ is large enough, for example around 0.9 , the first condition will be enough to lead to the result $\Delta a_{1}<\Delta a_{2}$ in this case.

For example, assume that $\delta=0.96, \gamma_{1}=0.6, \gamma_{2}=0.8, \gamma_{1}(P F A)=0.2, \gamma_{2}(P F A)=0.3$. Numerator - Denominator $=\left[\gamma_{1}-\gamma_{1}(P F A)-\gamma_{2}+\gamma_{2}(P F A)\right]+2(1-\delta) \cdot\left[\gamma_{1} \cdot \gamma_{2}(P F A)-\gamma_{2} \cdot \gamma_{1}(P F A)\right]+$
$(1-\delta)^{2} \cdot\left\{\gamma_{1} \cdot \gamma_{2}(P F A) \cdot\left[\gamma_{1}(P F A)+\gamma_{2}\right]-\gamma_{1}(P F A) \cdot \gamma_{2} \cdot\left[\gamma_{1}+\gamma_{2}(P F A)\right]\right\}$
$=-0.1+0.0016+0.0016 \times 0.03$
$=-0.098$

We can find that this example can satisfy the condition (1) $\gamma_{1}-\gamma_{1}(P F A)<\gamma_{2}-$ $\gamma_{2}(P F A)$ but not condition (2) $\frac{\gamma_{2}(P F A)}{\gamma_{1}(P F A)}<\frac{\gamma_{2}}{\gamma_{1}}$. However, the result satisfies $\Delta a_{1}<\Delta a_{2}$.

In sum, if the discount factor is large enough and getting PFA can bring the gap in agents' self-control costs closer, we can get the results $\Delta a_{1}<\Delta a_{2}$ in Hypothesis 3 . 